\title{
An updated review of nanofluids in various heat transfer devices
}

\author{
Eric C. Okonkwo ${ }^{1}$ (1) - Ifeoluwa Wole-Osho ${ }^{2} \cdot$ Ismail W. Almanassra $^{1} \cdot$ Yasser M. Abdullatif ${ }^{1} \cdot$ Tareq Al-Ansari $^{1,3}$
}

Received: 12 March 2020 / Accepted: 27 April 2020 / Published online: 15 June 2020

(c) The Author(s) 2020

\begin{abstract}
The field of nanofluids has received interesting attention since the concept of dispersing nanoscaled particles into a fluid was first introduced in the later part of the twentieth century. This is evident from the increased number of studies related to nanofluids published annually. The increasing attention on nanofluids is primarily due to their enhanced thermophysical properties and their ability to be incorporated into a wide range of thermal applications ranging from enhancing the effectiveness of heat exchangers used in industries to solar energy harvesting for renewable energy production. Owing to the increasing number of studies relating to nanofluids, there is a need for a holistic review of the progress and steps taken in 2019 concerning their application in heat transfer devices. This review takes a retrospective look at the year 2019 by reviewing the progress made in the area of nanofluids preparation and the applications of nanofluids in various heat transfer devices such as solar collectors, heat exchangers, refrigeration systems, radiators, thermal storage systems and electronic cooling. This review aims to update readers on recent progress while also highlighting the challenges and future of nanofluids as the next-generation heat transfer fluids. Finally, a conclusion on the merits and demerits of nanofluids is presented along with recommendations for future studies that would mobilise the rapid commercialisation of nanofluids.
\end{abstract}

Keywords Nanofluids $\cdot$ Heat transfer $\cdot$ Nanoparticles $\cdot$ Solar collector $\cdot$ Heat exchangers

$\begin{array}{ll}\text { Abbreviations } \\ \text { AARS } & \text { Ammonia absorption refrigeration system } \\ \text { AFM } & \text { Atomic force microscopy } \\ \text { AG } & \text { Arabic gum } \\ \text { ANN } & \text { Artificial neural network } \\ \text { CA } & \text { Citric acid } \\ \text { CFD } & \text { Computational fluid dynamics } \\ \text { CHF } & \text { Critical heat flux } \\ \text { CMC } & \text { Carboxymethyl cellulose } \\ \text { CNT } & \text { Carbon nanotubes } \\ \text { COP } & \text { Coefficient of performance }\end{array}$

Eric C. Okonkwo

eokonkwo@hbku.edu.qa

Tareq Al-Ansari

talansari@hbku.edu.qa

1 Division of Sustainable Development, College of Science and Engineering, Hamad Bin Khalifa University, Qatar Foundation, Education City, Doha, Qatar

2 Department of Energy Systems Engineering, Cyprus International University, North Cyprus, Turkey

3 Division of Engineering Management and Decision Sciences, College of Science and Engineering, Hamad Bin Khalifa University, Qatar Foundation, Education City, Doha, Qatar

$\begin{array}{ll}\text { CPC } & \text { Compound parabolic collectors } \\ \text { CPU } & \text { Central processing unit } \\ \text { CTAB } & \text { Cetrimonium bromide } \\ \text { DAPTC } & \text { Direct absorption parabolic trough collector } \\ \text { DASC } & \text { Direct absorption solar collector } \\ \text { DI } & \text { Deionised } \\ \text { DLS } & \text { Dynamic light scattering } \\ \text { EBT } & \text { Eriochrome Black T } \\ \text { EDX } & \text { Energy-dispersive X-ray spectroscopy } \\ \text { ETSC } & \text { Evacuated tube solar collector } \\ \text { FESEM } & \text { Field emission scanning electron microscope } \\ \text { FPC } & \text { Flat plate collector } \\ \text { FTIR } & \text { Fourier-transform infrared spectroscopy } \\ \text { GNP } & \text { Graphene nanoplatelets } \\ \text { HPSC } & \text { Heat pipe solar collector } \\ \text { HPSWH } & \text { Heat pipe solar water heater } \\ \text { HX } & \text { Heat exchangers } \\ \text { LFR } & \text { Linear Fresnel reflectors } \\ \text { MAAFG } & \text { Microwave-assisted acid-functionalised } \\ & \text { graphene } \\ \text { MCHS } & \text { Microchannel heat sink } \\ \text { MLG } & \text { Multilayer graphene } \\ \text { MWCNT } & \text { Multiwall carbon nanotubes } \\ \text { nePCM } & \text { Nano-encapsulated phase change materials } \\ & \end{array}$




$\begin{array}{ll}\text { OA } & \text { Oleylamine } \\ \text { PAO } & \text { Polyalphaolefin } \\ \text { PCM } & \text { Phase change materials } \\ \text { PEG } & \text { Polyethylene glycol } \\ \text { PTSC } & \text { Parabolic trough solar collectors } \\ \text { PV } & \text { Photovoltaic } \\ \text { PVA } & \text { Polyvinyl alcohol } \\ \text { PVP } & \text { Polyvinylpyrrolidone } \\ \text { PVT } & \text { Photovoltaic thermal collectors } \\ \text { SDBS } & \text { Sodium dodecylbenzene sulphonate } \\ \text { SDS } & \text { Sodium dodecyl sulphate } \\ \text { SEM } & \text { Scanning electron microscope } \\ \text { SWCNT } & \text { Single-wall carbon nanotube } \\ \text { TEM } & \text { Transmission electron microscope } \\ \text { TES } & \text { Thermal energy storage } \\ \text { VARS } & \text { Vapour absorption refrigeration system } \\ \text { VCRS } & \text { Vapour compression refrigeration systems } \\ \text { Vol\% } & \text { Volume per cent } \\ \text { XRD } & \text { X-ray powder diffraction } \\ \text { ZVI } & \text { Zero-valent iron }\end{array}$

\section{Introduction}

Energy is a very important quantitative property that must be transferred before any system can perform work. The transfer of energy can be done by either work or heat [1]. Heat is transferred from one system to another when there exists a temperature difference between the two systems and travels from high to low temperatures [2]. The science that describes the means and rate in which thermal (heat) energy is transferred is known as heat transfer. Heat transfer applications are experienced in our daily life; the human body, for instance, is constantly emitting heat, and humans adjust their body temperature to suit environmental conditions using clothing. Heat transfer is also used in our buildings to regulate temperature [3] and is necessary for cooking, refrigeration and drying. It is also directly applied in car radiators [4] and for temperature control in electronic devices [5]. Heat transfer is used in solar thermal collectors to convert solar energy to heat and power $[6,7]$ and used in thermal control elements in spacecraft [8]. In many of these devices, heat needs to be dissipated at a rapid rate to ensure effective operation and maximum efficiency within the system [9]. As technology evolves, devices have become smaller and thus require better thermal management. Essentially, the more compact the size, the larger the requirement for effective cooling technology [10]. Therefore, heat transfer enhancement is a very important area in thermal engineering.

Several techniques have been considered to improve the heat transfer coefficient between the working fluids and the fluid contact surfaces $[11,12]$. Conventional heat transfer fluids such as water, thermal oils and ethylene glycol/water have some limitations as their thermal properties are quite low when compared to those of solids, as shown in Fig. 1. The improvement in the thermal properties of these fluids through the addition of nanoscaled particles has led to an evolution in the study of heat transfer fluids. The suspension of these solid particles in the base fluid enhances the energy transmission in the fluid leading to improved thermal conductivity properties and better heat transfer characteristics [13]. The resultant fluids have been seen to possess higher values of thermal conductivity $[14,15]$. Choi and Eastman [15] were the first to name such fluids as nanofluids. Nanofluids are the engineered colloidal suspension of nanoscaled particles $(10-100 \mathrm{~nm})$ in a base fluid [16]. These particles are generally metals, metallic oxides or other carbon-based elements. Over a century ago, Maxwell [17] was the first to discuss the suspension of micro-scaled particles into a fluid. However, microparticles settled rapidly in the fluid leading to abrasion and clogging in the flow channel, limiting further research into suspensions in fluids. Furthermore, these fluids did not exhibit the significant enhancement witnessed today with the use of nanofluids. The introduction of nanoparticles has allowed for further investigation into colloidal dispersion in fluids. Nanoparticles are more stable when dispersed in fluids and tend to improve on the thermal properties of the fluids. Some other properties of nanofluids which make them adequate heat transfer fluids include the Brownian motion of particles, particle/fluid nanolayers and their reduced pump power when compared to pure liquids to achieve intensified heat transfer.

Despite these benefits, nanofluids still possess some application-based limitations. Issues of sedimentation and aggregation in the fluid have been raised, although the use of ultrasonication, $\mathrm{pH}$ modulation, magnetic stirring and the addition of surfactants has been recorded to improve the stability of the nanofluids [18]. Also, increasing the fluid circulation rate in the device reduces the possibilities of sedimentation, although this can lead to an erosion of heat transfer in the device or flow stream. Particles of larger sizes also tend to clog the flow channel, and there have been cases of pressure loss recorded in some devices due to the marginal increase in viscosity. Nanofluids are also expensive to prepare and toxic due to the reactive nature of the nanoparticles [19]. Over the past decade, emphasis on nanofluids research has been more apparent as shown in Fig. 2, which illustrates the number of publications involving nanofluids since 2010 . These studies include those related to their preparation, characterisation, measurement of their physical properties and their utilisation in various applications. The data presented in Fig. 2 were obtained by searching the word "nanofluids" in the Scopus database against titles, abstracts and keywords over the period presented. The search illustrates that approximately 3165 papers were published in 2019 alone, and this trend is expected to increase in the coming years. Incidentally, several 

conductivity difference between a commonly used base fluids and $\mathbf{b}$ commonly used nanoparticles
Fig. 1 Bulk material thermal

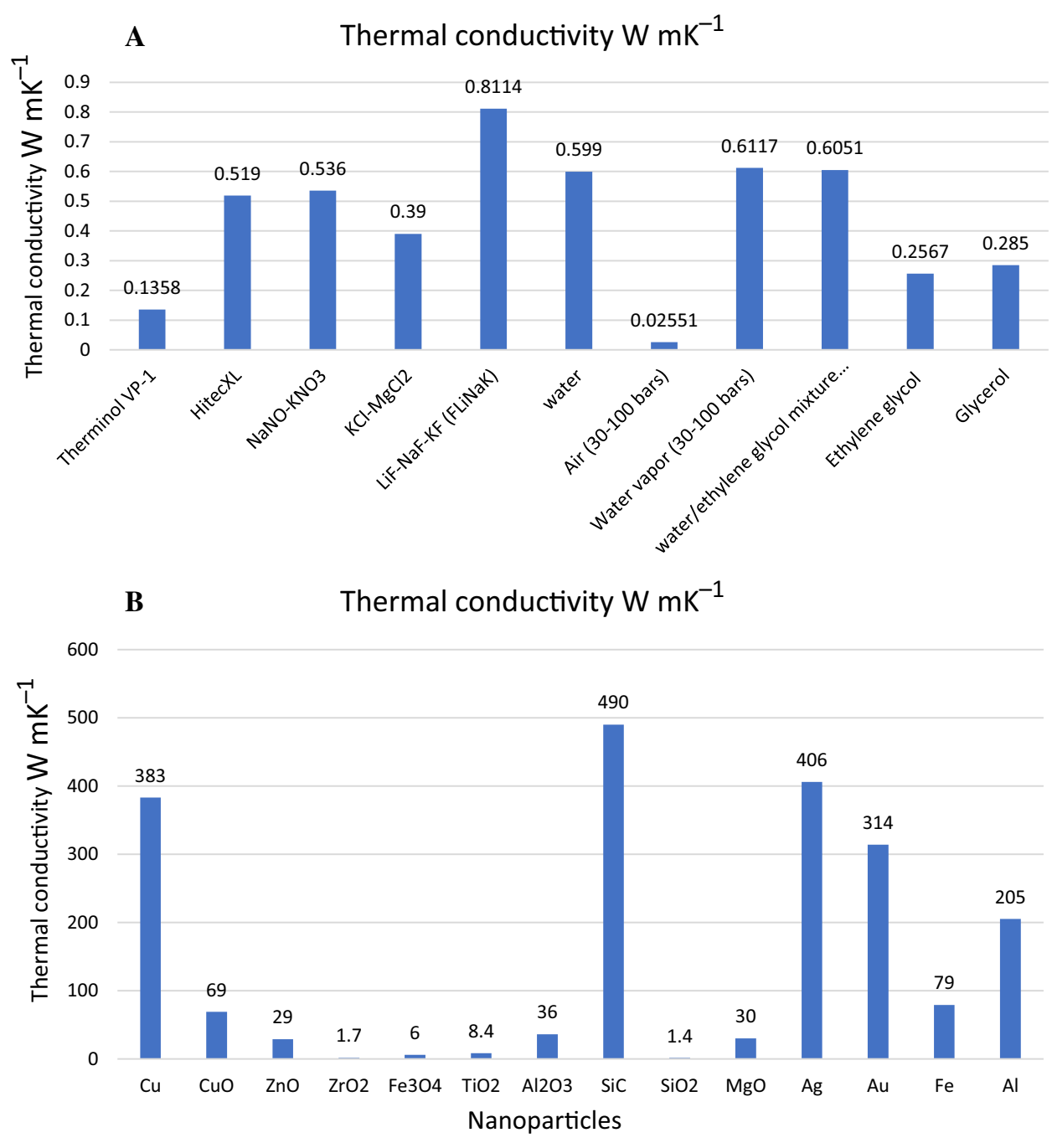

Fig. 2 Nanofluids-related publication in the past decade

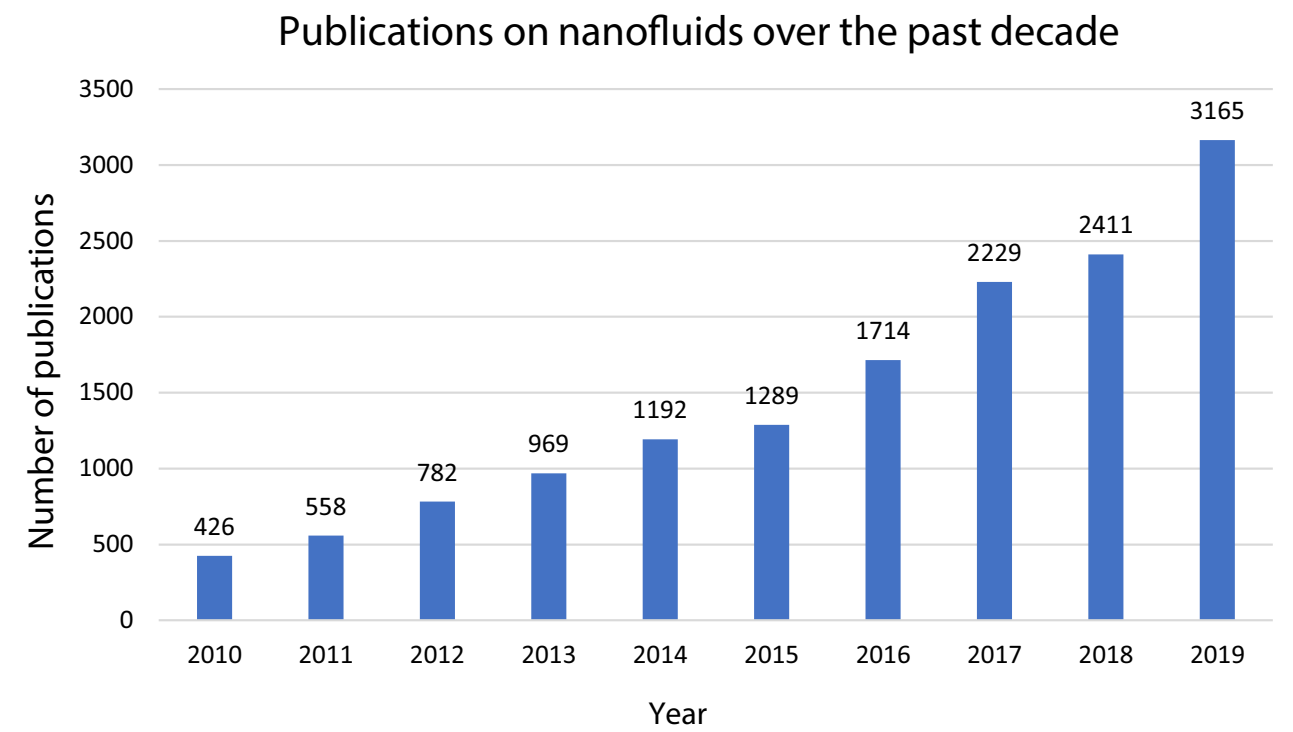


review papers related to the heat transfer properties and application of nanofluids were published in 2019. The reviews include solar collector applications [20,21], a review of nanofluids in heat exchangers [22, 23], review of nanofluids in heat pipes [24], radiator cooling [25], electronic cooling [5] and also a review on various thermophysical properties of nanofluids $[26,27]$. A list of some of the review papers published in 2019 is listed in Table 1.

Owing to the increasing number of studies relating to nanofluids, there is a need for a holistic review of the progress and steps taken in 2019 concerning their application in heat transfer devices. This study adopts a retrospective look at the year 2019 by reviewing the progress made in the area of nanofluids preparation, nanofluid thermophysical properties measurements and the applications of nanofluids in various heat transfer devices including solar collectors, heat exchangers, refrigeration systems, radiators, thermal storage systems and electronic cooling. The study aims to update readers on recent progress in nanofluid synthesis and application. The study also seeks to highlight the challenges and prospects of nanofluids as the next-generation heat transfer material.

\section{Preparation of nanofluids}

The method used in the preparation of nanofluids is important in the study of the stability and thermophysical behaviour of nanofluids [57]. The preparation steps are also vital in estimating the degree to which the nanofluids are employed in heat transfer systems [58], [59]. In this section, the studies related to nanofluid stability and their synthesis techniques are discussed. Nanofluids are produced by suspending particles of nanosize dimensions in the traditional heat transfer fluids such as water, oils, acetone and glycols [60]. A wide range of nanoparticles have been utilised in the formation of nanofluids, some of these include:
Table 1 Reviews on heat transfer-related application of nanofluids published in 2019

\begin{tabular}{|c|c|c|}
\hline References & Application reviewed & $\begin{array}{l}\text { Number of } \\
\text { reviewed } \\
\text { papers }\end{array}$ \\
\hline [28] & Nanofluids in solar dish concentrators & 125 \\
\hline [29] & Enhancement of solar energy systems & 133 \\
\hline [30] & $\begin{array}{l}\text { A 10-year review of nanofluids in solar thermal collectors, hybrid PV/T and } \\
\text { direct steam generation }\end{array}$ & 100 \\
\hline [31] & Performance of solar collectors using carbon-based nanofluids & 130 \\
\hline [32] & Performance of PVT systems using nanofluids & 178 \\
\hline [33] & Nanofluids in heat exchangers for energy savings & 320 \\
\hline [34] & Hybrid nanofluids in solar collectors & 187 \\
\hline [35] & Nanofluids in solar collectors & 204 \\
\hline [36] & Application of carbon-based nanofluids in heat exchangers & 152 \\
\hline [37] & Effect of using nanofluids in several types of heat pipes & 73 \\
\hline [38] & Review of experimental studies using nanofluids in heat pipes & 127 \\
\hline [39] & Hybrid nanofluids in solar collectors & 261 \\
\hline [40] & Review of heat pipe using mono and hybrid nanofluids as working medium & 113 \\
\hline [41] & Factors affecting the use of nanofluids in flat plate solar collectors & 116 \\
\hline [42] & Review of nanofluids in solar collectors & 93 \\
\hline [43] & Water-based nanofluids in PVT & 39 \\
\hline [44] & Thermal enhancement of parabolic through collectors using nanofluids & 87 \\
\hline [45] & Nanofluids in automobile cooling & 172 \\
\hline [46] & Nanofluids used for direct absorption solar collectors & 76 \\
\hline [47] & Nanofluids in concentrating solar collectors & 140 \\
\hline [48] & Application of nanofluids in solar collectors, heat exchangers and radiators & 108 \\
\hline [49] & Nanofluids in flat plate solar collectors & 105 \\
\hline$[50]$ & The effect of nanofluid fuels on compression ignition engines & 73 \\
\hline [51] & Nanofluids in double-pipe heat exchangers with twisted tape & 53 \\
\hline [52] & Concentrating solar collectors & 123 \\
\hline [53] & Nanofluids in parabolic trough collectors & 192 \\
\hline [54] & Nanofluids in thermal photovoltaic systems & 55 \\
\hline [55] & Nanofluids in car radiators & 93 \\
\hline [56] & Nanofluids in phase change materials & 135 \\
\hline
\end{tabular}


(1) Carbon nanoparticles (such as MWCNT, SWCNT, Gn, $\mathrm{GO}$, graphite, diamond and fullerene).

(2) Metal nanoparticles (such as $\mathrm{Ag}, \mathrm{Al}, \mathrm{Au}, \mathrm{Co}, \mathrm{Cu}$ and $\mathrm{Fe})$.

(3) Metal oxide nanoparticles (such as $\mathrm{Al}_{2} \mathrm{O}_{3}, \mathrm{CeO}_{2}, \mathrm{CuO}$, $\mathrm{Fe}_{3} \mathrm{O}_{4}, \mathrm{TiO}_{2}$ and $\mathrm{ZnO}$ ).

(4) Others (such as $\mathrm{Si}, \mathrm{AlN}-\mathrm{C}, \mathrm{CoFe}_{2} \mathrm{O}_{4}, \mathrm{SiC}$, Field's alloy nanoparticles, $\mathrm{ZnBr}_{2}$ and $\mathrm{SiO}_{2}$ ).

Nanofluids can be unstable due to the strong Van der Waals interactions and cohesive forces between nanoparticles. Therefore, the preparation technique used is extremely important in others to break down these forces and produce stable nanofluids. Different methods have been used to avoid nanoparticle agglomeration and improve the stability of nanofluids, such as $\mathrm{pH}$ control, surfactant addition, ultrasonic agitation, magnetic stirring, functionalisation and high-pressure homogenisation [61]. According to Yu and Xie [61], there are three main methods used for nanofluids preparation: one-step chemical technique, one-step physical technique and two-step technique.

The two-step technique is the most widely used for nanofluid preparation, and it is more economical for mass production. In this method, the industrial or laboratory-synthesised nanoparticles are dispersed in the base fluids by agitation, stirring or ultra-sonication [60]. A significant drawback of this technique is it often has low stability and a high tendency of agglomeration. To avoid this problem, several additional techniques, including one-step synthesis techniques and green synthesis techniques, have been used. The twostep nanofluid preparation technique is illustrated in Fig. 3.

Asadi et al. [62] prepared MWCNT/water nanofluid by implementing the two-step method without using surfactants, and both agitation and ultra-sonication were used in the nanofluid preparation. Their nanofluid was stable for one month. However, with the addition of surfactants, Chen et al. [63] adopted the two-step method to prepare MWCNT/ DI water using polyvinylpyrrolidone (PVP) as a surfactant. They performed ultra-sonication for only one hour, and they obtained a stable solution for more than two months. Additionally, Almanassra et al. [64] used the two-step method to investigate the stability and thermophysical properties of MWCNT/water nanofluids using different surfactants PVP, SDS and AG. They prepared the nanofluids using ultra-sonication for $30 \mathrm{~min}$, and the solutions were stable for more than six months. Other studies have used different surfactants such as SDBS, CTAB, oleic acid, ethyl carbamate, PEG, EBT, oleylamine, citric acid, Tween 80, Gemini's and APTMS. The use of surfactants depends on the nature of the base fluid and type of nanoparticles. The surfactants act as a bridge between the base fluids and the nanoparticles. It increases the repulsive forces between the particles and decreases the interfacial tension between the base fluids and suspended nanoparticles. Surfactants also increase the zeta potential of nanoparticles and increase the hydrophilic properties of the suspended particles. Surfactants are classified based on the charge of their head group. Therefore, the surfactants might be cationic (positively charged) such as CTAB, distearyl dimethylammonium chloride and benzalkonium chloride; non-ionic (uncharged, neutral) such as oleic acid, PVP, AG, Tween 80 and oleylamine; anionic (negatively charged) such as SDBS and SDS; and amphoteric (negatively and positively charged) such as lecithin.

Hydrophobic materials are generally chemically or physically pre-treated to improve the particle's hydrophilicity and their stability in the base fluids. Liu et al. [65] used the two-step method to prepare $\mathrm{GO} /$ water nanofluids with particle concentration of $\left(1-4.5 \mathrm{mg} \mathrm{mL}^{-1}\right)$. GO was initially prepared from graphite using the Hummers method; then, nanofluids were prepared using both agitation and ultra-sonication for $40 \mathrm{~min}$ and $1 \mathrm{~h}$, respectively. The nanofluids showed good stability for more than three
Fig. 3 Two-step method of preparing nanofluids. (modified from [33])

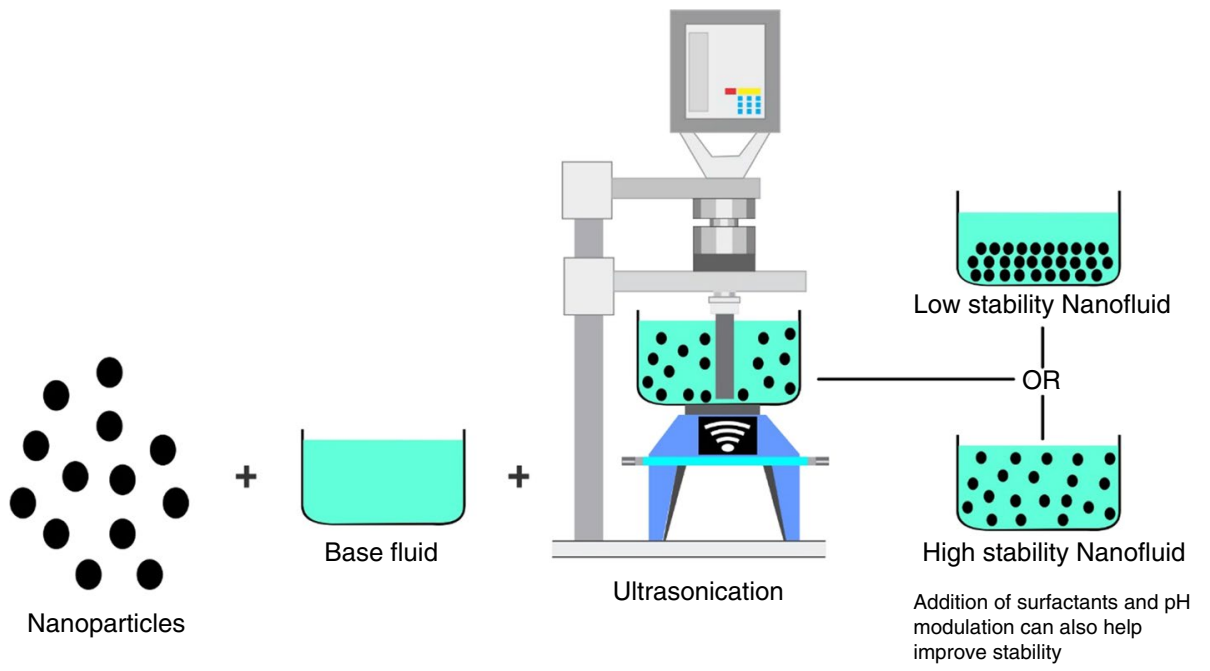


months. Albert et al. [66] used the sol-gel method using PVA as a surfactant to prepare $\mathrm{CuO} /$ water nanofluids. The nanofluids were ultra-sonicated for $1.75 \mathrm{~h}$ and remained stable for more than a year. Yang et al. [67] investigated $\mathrm{TiO}_{2} /$ water and $\mathrm{Ag} /$ water nanofluids for heat recovery using the two-step method of nanofluid preparation. The particles were prepared using the post-treated optimised preparation method, which involves separating the agglomerated particles and studying the stability and heat recovery of the remaining concentration of nanoparticles. The nanofluids prepared using this method were stable for more than six months.

In the single-step method, both steps, (i) formation of particles and (ii) dispersing them in the base fluids, happen simultaneously. In this method, all the intermediate processes such as storage, drying, dispersion of particles and transportation are subtracted or avoided, so the accumulation of nanoparticles decreased, and stability of nanofluids is maximised. Huang et al. [68] adopted the single-step method to prepare ethyl carbamate-modified Field's alloy/polyalphaolefin (PAO) oil nanofluids using the nano-emulsification technique. In this technique, the Field's alloy nanoparticles are heated up to $180{ }^{\circ} \mathrm{C}$ in the PAO oil under stirring for $3 \mathrm{~h}$. The nanofluids were considered ready by observing the colour change from white to dark grey. According to the UV-Vis spectra results and zeta potential values, the nanofluids remain stable for more than $3 \mathrm{~h}$.

Moreover, Du et al. [69] considered the one-step method to produce $\mathrm{Gn} /$ water nanofluids based on the shear exfoliation of graphite with the help of PVA surfactant. In this method, the graphite was converted to graphene within the DI water by six exfoliation processes. The authors observed a stable solution for more than $180 \mathrm{~h}$ by monitoring the UV-Vis spectra. Additionally, Li et al. [70] prepared silver and gold water-based nanofluids using the one-step method. The authors examined the effect of spacer length of different Gemini surfactants on the stability of silver and gold nanofluids. Furthermore, silver and gold solutions were added to the pre-prepared surfactant solution with the addition of glucose and sodium hydroxide under vigorous stirring till a red colour was observed. According to their stability study, the solutions remained stable for more than 60 days.

The one-step method can be used only in small-scale production. Using this method can produce well uniform dispersed nanofluids, although it is costly, and not all types of nanofluids can be produced by this method. For the readers' convenience, the authors have summarised some of the works on nanofluids preparation in the year 2019 in Table 2. The table summarises the nanoparticles types, base fluids and the methods used for the nanoparticles and nanofluids synthesis, characterisation and stability measurement.

\section{Properties of various nanofluids}

The thermophysical behaviour of nanofluids directly affects the application of nanofluids, especially concerning heat transfer. Properties such as the viscosity, thermal conductivity, density and the specific heat capacity of the fluid are all vital in determining the effectiveness of nanofluids as heat transfer fluids. Experimentally, certain techniques and standards have been used in measuring the various thermophysical properties of nanofluids.

The three main techniques in measuring the thermal conductivity of nanofluids are the transient technique, steady-state technique and the thermal comparator [98]. The transient technique is more accurate and reliable than the steady-state technique, as it completely reduces the effect of natural convection and radiation [99]. Rotational viscometers are the main type of instruments used to measure the viscosity of nanofluids. These viscometers do not only measure the viscosity of the fluid, but they can also determine the rheological behaviour of the fluids. On the other hand, the specific heat capacity of nanofluids is usually measured by applying the differential scanning calorimetry (DSC) as it is easy to use, provides adequate accuracy and the measurement times are short. While there have been many studies that measured nanofluids thermophysical properties using the outlined techniques, many other researchers have focused their studies on proving an accurate theoretical model to predict the thermophysical behaviour on nanofluids.

Before the invention of nanofluids, several scientists have theorised the effect of particle dispersion on the thermophysical properties of conventional heat transfer fluids. As previously stated, J. C. Maxwell theorised the thermal conductivity of particle dispersions in a liquid in 1881 [17]. Later, Einstein theorised the dynamic viscosity of particle dispersions in a liquid in 1905. Both research endeavours represent the earliest postulations of the thermophysical behaviour of suspensions in fluids [100]. Several other researchers have proposed models to predict these thermophysical behaviours of suspensions in fluids. Theoretical models developed before the classification of nanofluids are known as classical models. Table 3 illustrates the classical models for predicting the thermophysical properties of nanofluids. While the classical models were accurate to a limited range, the models often did not predict the values of thermal conductivity, viscosity and specific heat capacity of the nanofluid with high enough levels of accuracy. This is mainly because, in the nanoscale, previously unconsidered factors appear to affect the thermophysical properties of fluid dispersion, while most classical models considered volume concentration and the base fluid property as the most important 


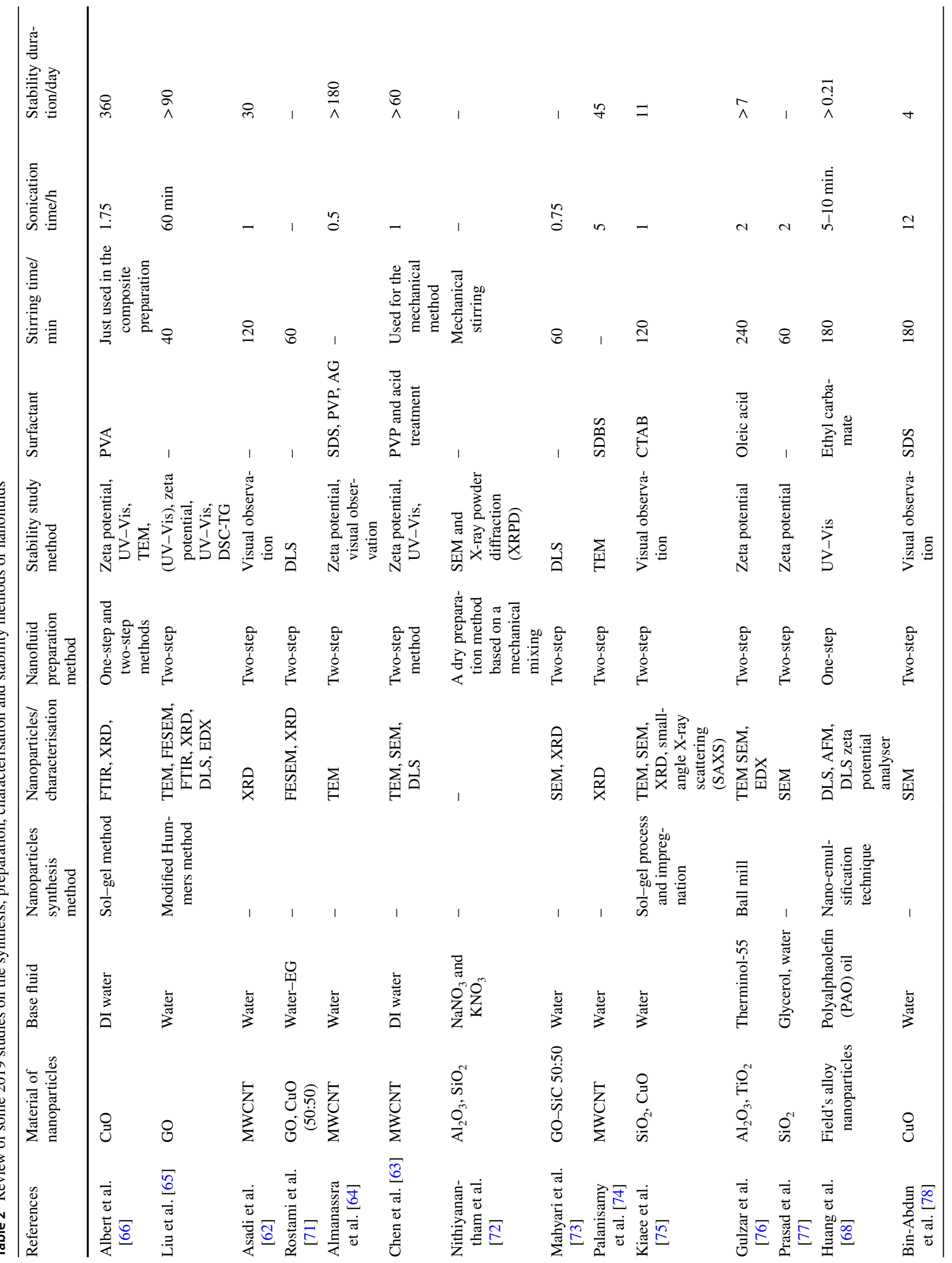




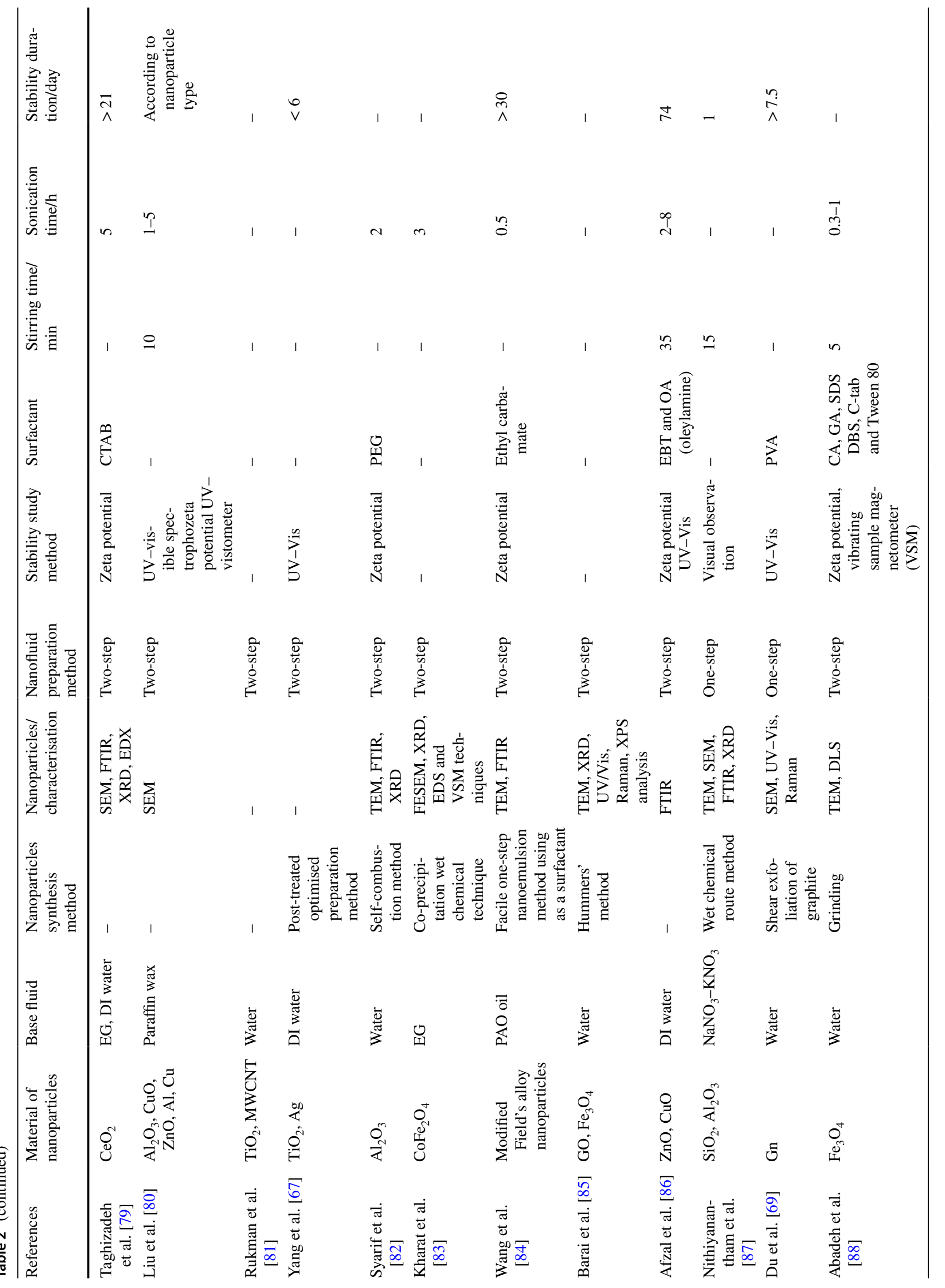




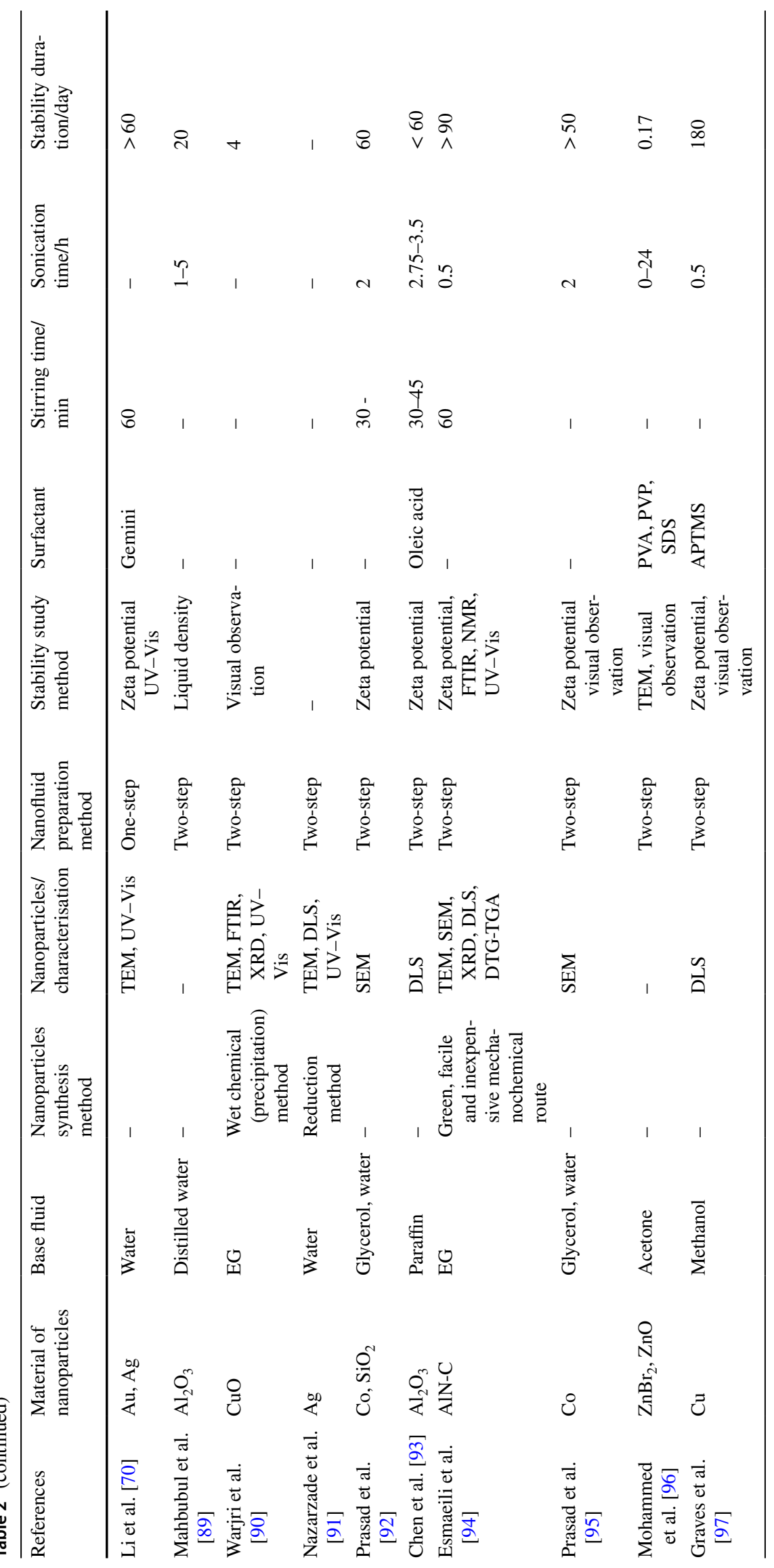


Table 3 Classical formulas for the thermal conductivity and viscosity of dispersions in fluids

\begin{tabular}{llll}
\hline Model & Property & Formula & Year \\
\hline Einstein model [100] & Viscosity & $\frac{\mu_{\mathrm{eff}}}{\mu_{\mathrm{f}}}=1+2.5 \varphi$ & 1905 \\
Mooney model [102] & Viscosity & $\frac{\mu_{\mathrm{eff}}}{\mu_{\mathrm{f}}}=e^{\frac{2.5 \varphi}{1-\mathrm{k} \varphi}}$ & 1951 \\
Krieger-Dougherty model [103] & Viscosity & $\frac{\mu_{\mathrm{eff}}}{\mu_{\mathrm{f}}}=1-\frac{\varphi}{\varphi_{\mathrm{m}}}-2.5 \varphi_{\mathrm{m}}$ & 1959 \\
Nielsen power law model [104] & Viscosity & $\mu_{\mathrm{eff}}=\left(e^{\frac{\varphi}{1-\varphi_{\mathrm{m}}}}\right) \mu_{\mathrm{f}}$ & 1970 \\
Batchelor model [105]. & Viscosity & $\mu_{\mathrm{eff}}=\left(1+2.5 \varphi+6.5 \varphi^{2}\right) \mu_{\mathrm{f}}$ & 1977 \\
Maxwell model [17] & Thermal conductivity & $\frac{k_{\text {eff }}}{k_{\mathrm{f}}}=\frac{k_{\mathrm{p}}+2 k_{\mathrm{f}}+2\left(k_{\mathrm{p}}-k_{\mathrm{f}}\right) \varphi}{k_{\mathrm{p}}+2 k_{\mathrm{f}}-\left(k_{\mathrm{p}}-k_{\mathrm{f}}\right) \varphi}$ & 1881 \\
Bruggeman model [106] & Thermal conductivity & $\varphi\left(\frac{k_{\mathrm{p}}-k_{\mathrm{eff}}}{k_{\mathrm{p}}+2 k_{\mathrm{eff}}}\right)+(1-\varphi)\left(\frac{k_{\mathrm{f}}-k_{\mathrm{eff}}}{k_{\mathrm{f}}+2 k_{\mathrm{eff}}}\right)=0$ & 1935 \\
Hamilton-Crosse model [107] & Thermal conductivity & $k_{\mathrm{eff}}=\frac{k_{\mathrm{p}}+(n-1) k_{\mathrm{f}}-(n-1)\left(k_{\mathrm{f}}-k_{\mathrm{p}}\right) \varphi}{k_{\mathrm{p}}+(n-1) k_{\mathrm{f}}-\left(k_{\mathrm{f}}-k_{\mathrm{p}}\right) \varphi} k_{\mathrm{f}}$ & 1962 \\
& & where $n=\frac{3}{\psi}$ & 1970 \\
Wasp model [104] & & $\frac{k_{\text {eff }}}{k_{\mathrm{f}}}=\frac{k_{\mathrm{p}}+2 k_{\mathrm{f}}-2 \varphi\left(k_{\mathrm{f}}-k_{\mathrm{p}}\right)}{k_{\mathrm{p}}+2 k_{\mathrm{f}}-\varphi\left(k_{\mathrm{f}}-k_{\mathrm{p}}\right.}$ & \\
\hline
\end{tabular}

where $\mu_{\mathrm{eff}}, \mu_{\mathrm{f}}, \varphi, k_{\mathrm{p}}, k_{\mathrm{f}}, k_{\mathrm{eff}}$ and $\varphi_{\mathrm{m}}$ represent the effective viscosity, fluid viscosity, volume concentration, thermal conductivity of the particles and fluid, respectively, effective thermal conductivity and packing fraction. $n$ and $\psi$, however, are constants that depend on both the shape of the dispersed particles and the ratio of the conductivities of the two phases variables in determining the thermophysical properties as Einstein described it as "small rigid spheres suspended in a liquid". However, research deduced that nanofluids thermophysical properties are affected by a broader range of variables which include particle size [101], volume concentration, base fluid property, particle agglomeration, packing fraction, fluid $\mathrm{pH}$, nanolayers, particle distribution, temperature and mixture ratio (hybrid nanofluids). The inability of the classical models to factor in these variable conditions limits its application to only a narrow range of values.

The physical properties of the nanofluids are an important parameter in predicting the heat transfer and friction factor behaviours of individual nanofluids. Mahian et al. [108], summarised the computational methods for solving the thermal transport model for nanofluids flow. These methods include the finite differential method, finite volume method, finite element method, lattice Boltzmann methods and other Lagrangian methods such as dissipative particle dynamics and molecular dynamics. Based on experimental results, Dadhich et al. [109] used the artificial neural network to develop correlations used to predict the heat transfer coefficient of $\mathrm{Al}_{2} \mathrm{O}_{3}$ and $\mathrm{TiO}_{2}$ water-based nanofluids flowing in an annulus at 1 bar. The three input parameters used in their study were nanoparticle concentration, heat flux and mass flux. Their results show that both nanofluids performed better than water. At a nanoparticle concentration of $0.2 \%$, $\mathrm{Al}_{2} \mathrm{O}_{3}$ nanofluid had enhancement of $155.24 \%$ and $\mathrm{TiO}_{2}$ nanofluid had a heat transfer coefficient increase of $71.56 \%$ as compared to that of water. The heat transfer and friction factor behaviour hybrid nanofluids have also been investigated. Yang et al. [110] investigated the dynamic stability, sedimentation and time-dependent heat transfer characteristics of $\mathrm{TiO}_{2}$ and CNT nanofluids. They discovered that for a volumetric concentration of $0.3 \% \mathrm{TiO}_{2}$ and $0.1 \%$ CNT nanofluids, the convective heat transfer coefficient is increased by $17.84 \%$ and $19.31 \%$, respectively. Hameed et al. [111], from experimental data, compared the heat transfer and pressure drop behaviour of alumina-CNT/water nanofluids and alumina- $\mathrm{Cu}$ /water nanofluids. The convective heat transfer enhancement of alumina-CNT/water was higher compared to alumina- $\mathrm{Cu} /$ water hybrid fluid. The maximum enhancements of $30.65 \%$ and $20.48 \%$ in Nusselt number were obtained at $0.3 \%$ volume fraction of alumina-CNT/water and alumina-Cu/water hybrid nanofluid, respectively. Their study provided experimental correlation for both fluids.

\section{Thermal conductivity of nanofluids}

Yu et al. [112] conducted a review over a decade ago to compare the thermal conductivity of nanofluids and their convective heat transfer enhancement. They concluded that from 107 works of literature surveyed, a 15-40\% enhancement was recorded with the oxides nanoparticles available back then. Today, numerous research investigating the use of different nanoparticles on the thermal conductivity has been conducted. Esfe and Afrand [113] extensively covered the thermal conductivity of nanofluids that predate 2019. In 2019, as it has been the trend, a majority of the studies focused on hybrid nanofluids. Akhgar et al. [114] 
experimentally measured the thermal conductivity of MWCNT- $\mathrm{TiO}_{2}$ /ethylene glycol nanofluid and obtained that an increase in volume concentration of the nanofluid tends to increase the thermal conductivity of the hybrid nanofluid. The study considered volume concentration between 0.05 and $1 \%$ and observed that at a volume concentration of $1 \%$, maximum enhancement (40.1\%) in thermal conductivity was obtained. The study also developed an artificial neural network (ANN) model to predict the thermal conductivity values obtained from the experiment. Also, Alarifi et al. [115] developed an ANN model from their experimental results to predict the thermal conductivity of $\mathrm{MWCNT}-\mathrm{TiO}_{2}$ /thermal oil nanofluid.

As shown in Table 4, while many studies have begun to use the artificial neural network (ANN) models in thermal conductivity prediction, some others have proposed regression-based correlation equations to fit results obtained from their experiments. Moldoveanu et al. [116] conducted an experimental study on the thermal conductivity variation of $\mathrm{Al}_{2} \mathrm{O}_{3}-\mathrm{TiO}_{2}$ /water nanofluid at volume concentration between 0.25 and $1 \%$ and proposed a correlation model to predict the thermal conductivity.

In terms of unique conventional nanofluids, Essajai et al. [117] studied the effect of particle shape on the thermal conductivity of nanofluids. The study was performed using a one-dimensional (1-D) network of interconnected gold nanoparticles (IAuNPs) and spherical Au nanoparticles. It was observed that IAuNPs in base fluids were more effective in improving the thermal conductivity of nanofluids than spherical Au particles suspended in a base fluid. Applying the one-step synthesis technique, the stability and the thermal conductivity measurement of MWCNTs/Jatropha seed oil nanofluid were investigated [118]; this environmentfriendly nanofluid showed a thermal conductivity enchantment of $6.76 \%$ at a mass concentration of $0.8 \%$.

ANN has also been used to predict the effect of particle aggregation on the thermal conductivity of nanofluids [119]. Mirsaeidi and Yousef [120] used ANN to predict the thermal conductivity, density and viscosity of carbon quantum dots nanofluids using water, ethylene glycol and EG-water (60:40) as base fluids. Motlagh et al. [121] used gene expression programming to propose a correlation that estimates the thermal conductivity of $\mathrm{Al}_{2} \mathrm{O}_{3}$ and $\mathrm{CuO}$-water-based nanofluid based on experimental data from the literature. Going forward, it is expected that there will be an increase in research and development exploring the possible advantages of using ternary hybrid nanofluids. In this regard, the study conducted by Mousavi et al. [122] has already demonstrated that the thermal conductivity of $\mathrm{CuO}-\mathrm{MgO}-\mathrm{TiO}_{2} /$ water nanofluid is enhanced by $78.6 \%$ at a mass fraction of 0.1 . For the reader's convenience, the authors have summarised the work on thermal conductivity studies for hybrid nanofluids in the year 2019 in Table 4.

\section{Viscosity of nanofluids}

The viscosity of a fluid is important in understanding both the heat transfer and the flow behaviour of the fluid. Several experimental studies have been carried out to understand the behaviour of nanofluids. The available research on the topic is not limited to experiments alone as molecular dynamics simulations have also been used to explain the viscosity of nanofluids [136]. Dehghani et al. [137] analysed the effect of temperature and mass fraction of $\mathrm{Al}_{2} \mathrm{O}_{3}$ and $\mathrm{WO}_{3}$ nanoparticles in water and liquid paraffin. Their findings showed that the viscosity of both nanofluids is increased only by adding a certain number of nanoparticles to both fluids. Regarding the shear rates, the viscosity of water-based nanofluids is constant, which indicates a Newtonian behaviour, while that of paraffin does not remain constant at different shear rates, and at a low amount of shear rate the viscosity achieves higher value, indicating a non-Newtonian behaviour for liquid paraffin-based nanofluids. Finally, they presented a correlation based on temperature, nanoparticle concentration and the physical properties of both the nanoparticle and base fluid for predicting the viscosity of aqueous and non-aqueous nanofluids. Ye et al. [138] extensively covered the viscosity of nanofluids that predate 2019. In 2019, as with thermal conductivity studies, there has been a trend towards hybrid nanofluids. The significance of viscosity in lubrication applications has been seen in many investigations related to oil-based nanofluids. Using the ultrasonic-assisted process, Barai et al. [85] synthesised graphene oxide- $\mathrm{Fe}_{3} \mathrm{O}_{4} /$ water nanofluid at volume concentrations between 0.01 and $0.2 \%$. The study obtained a maximum viscosity enhancement of $41 \%$. Studying $\mathrm{Fe}-\mathrm{CuO} / \mathrm{EG}-$ water nanofluid, Bahrami et al. [139] obtained that the backward propagation methods presented the least error in predicting dynamic viscosity. Bahrami et al. [139] deduced that when the hybrid nanofluids volume concentration is below $0.1 \%$, the $\mathrm{Fe}-\mathrm{CuO} / \mathrm{EG}$-water nanofluid exhibited Newtonian behaviour. However, when $\mathrm{Fe}-\mathrm{CuO} / \mathrm{EG}-$ water nanofluid volume concentration is above $0.25 \%$ the behaviour of the fluid changed.

As shown in Table 5, while many studies have proposed various correlation models to predict the viscosity behaviour of nanofluids, the more accurate models proposed are the artificial neural network (ANN) models. Ruhani et al. [140] investigated the effects of volume concentration and fluid temperature on the viscosity of hybrid nanofluids. The correlation model proposed in this study demonstrated a $1.8 \%$ margin of deviation between experimental values and correlation results. Viscosity enhancement was about $80 \%$ when the volume fraction was $2 \%$.

Other types of conventional nanofluids were also studied; Mousavi et al. [141] conducted an experimental investigation into the viscosity measurements of $\mathrm{MoS}_{2} /$ diesel oil nanofluid at particle concentration between 0.1 and $0.7 \%$. The study 
Table 4 Thermal conductivity studies of hybrid nanofluids in 2019

\begin{tabular}{|c|c|c|c|c|c|c|c|c|}
\hline References & Particle A & Particle B & Size particle A & $\begin{array}{l}\text { Size particle } \\
\text { B }\end{array}$ & Base fluid & Concentration & $\begin{array}{l}\text { Predictive } \\
\text { model }\end{array}$ & $\begin{array}{l}\text { Thermal } \\
\text { conductivity } \\
\text { enhancement/ } \\
\%\end{array}$ \\
\hline $\begin{array}{l}\text { Akhgar et al. } \\
\text { [114] }\end{array}$ & MWCNTs & $\mathrm{TiO}_{2}$ & $\begin{array}{l}\text { Outer diam- } \\
\text { eter } 20-30 \mathrm{~nm} \text {, } \\
\text { inner diam- } \\
\text { eter } 5-10 \mathrm{~nm}\end{array}$ & 30 & $\begin{array}{c}\text { Water/EG } \\
(50: 50)\end{array}$ & $0.05-1 \%$ & $\begin{array}{l}\text { Levenberg- } \\
\text { Marquardt } \\
\text { ANN }\end{array}$ & 40.1 \\
\hline $\begin{array}{l}\text { Taherialek- } \\
\text { ouhi et al. } \\
{[123]}\end{array}$ & $\begin{array}{l}\text { Graphene } \\
\text { oxide }\end{array}$ & $\mathrm{Al}_{2} \mathrm{O}_{3}$ & 3.4-7 (thickness) & 20 & Water & $0.1-1 \%$ & $\begin{array}{c}\text { Correlation } \\
\text { equation }\end{array}$ & 39.3 \\
\hline $\begin{array}{l}\text { Nithiyanan- } \\
\text { tham et al. } \\
{[87]}\end{array}$ & $\mathrm{SiO}_{2} @ \mathrm{Al}_{2} \mathrm{O}_{3}$ & core-shell & $\begin{array}{l}12-17 \text { outer shell th } \\
2-5 \mathrm{~nm}\end{array}$ & ickness & Molten salt & $1 \%$ & NA & 19 \\
\hline $\begin{array}{l}\text { Alarifi et al. } \\
\text { [115] }\end{array}$ & MWCNT & $\mathrm{Al}_{2} \mathrm{O}_{3}$ & $\begin{array}{l}\text { Outside diam- } \\
\text { eter } 20-30 \mathrm{~nm} \text {; } \\
\text { inside diameter } \\
5-10 \mathrm{~nm}\end{array}$ & 20 & Thermal oil & $0.125-1.5 \%$ & ANFIS-ANN & 45 \\
\hline $\begin{array}{l}\text { Akilu et al. } \\
\text { [124] }\end{array}$ & $\mathrm{SiC}$ & $\mathrm{CuO} / \mathrm{C}$ & $45-65$ & $22-35$ & EG & $0.5-3.13 \%$ & $\begin{array}{c}\text { Correlation } \\
\text { equation }\end{array}$ & 19.3 \\
\hline $\begin{array}{l}\text { Shahsavar } \\
\text { et al. [125] }\end{array}$ & CNT & $\mathrm{Fe}_{3} \mathrm{O}_{4}$ & $\begin{array}{l}\text { Outer diameter } \\
10-30 \mathrm{~nm} \text { and } \\
\text { length } 10 \mu \mathrm{m}\end{array}$ & NA & Water & $0.2-2.25 \%$ & $\begin{array}{c}\text { Correlation } \\
\text { equation }\end{array}$ & 46 \\
\hline $\begin{array}{l}\text { Okonkwo } \\
\text { et al. [14] }\end{array}$ & $\mathrm{Al}_{2} \mathrm{O}_{3}$ & $\mathrm{Fe}$ & 29 & 46 & Water & $0.05-0.2 \%$ & NA & 14 \\
\hline $\begin{array}{l}\text { Arani and } \\
\text { Pourmogh- } \\
\text { adam[126] }\end{array}$ & MWCNTs & $\mathrm{Al}_{2} \mathrm{O}_{3}$ & $\begin{array}{l}\text { Outside diam- } \\
\text { eter: } 5-15 \mathrm{~nm} \text {, } \\
\text { Inside diam- } \\
\text { eter: } 3-5 \mathrm{~nm} \text {, } \\
\text { Length: } \sim 50 \mathrm{~nm}\end{array}$ & 20 & EG & $0.02-0.8 \%$ & $\begin{array}{l}\text { Correlation } \\
\text { equation }\end{array}$ & 17 \\
\hline $\begin{array}{l}\text { Arasu et al. } \\
\text { [127] }\end{array}$ & $\mathrm{TiO}_{2}$ & $\mathrm{Ag}$ & NA & NA & Water & 0.15 vol $\%$ & NA & 12.2 \\
\hline $\begin{array}{r}\text { Moldoveanu } \\
\text { et al. [116] }\end{array}$ & $\mathrm{Al}_{2} \mathrm{O}_{3}$ & $\mathrm{TiO}_{2}$ & 43 & 30 & Water & $1.0-3.0 \%$ & $\begin{array}{l}\text { Correlation } \\
\text { equation }\end{array}$ & 19.2 \\
\hline $\begin{array}{l}\text { Rubasingh } \\
\text { et al. [128] }\end{array}$ & $\mathrm{TiO}_{2}$ & $\mathrm{ZnO}$ & NA & NA & EG & $1-8 \%$ & $\begin{array}{l}\text { Correlation } \\
\text { equation }\end{array}$ & 33 \\
\hline $\begin{array}{l}\text { Sulgani and } \\
\text { Karimipour } \\
\text { [129] }\end{array}$ & $\mathrm{Al}_{2} \mathrm{O}_{3}$ & $\mathrm{Fe}_{2} \mathrm{O}_{3}$ & 20 & $20-40$ & $\begin{array}{l}\text { 10w40-engine } \\
\text { oil }\end{array}$ & $0.25-4 \%$ & $\begin{array}{l}\text { Correlation } \\
\text { equation }\end{array}$ & 33 \\
\hline $\begin{array}{l}\text { Mousavi et al. } \\
\text { [130] }\end{array}$ & $\mathrm{MgO}$ & $\mathrm{TiO}_{2}$ & $25-45$ & $18-23$ & Water & $0.1-0.5 \mathrm{Vol} \%$ & $\begin{array}{c}\text { Correlation } \\
\text { equation }\end{array}$ & 35 \\
\hline $\begin{array}{l}\text { de Oliveira } \\
\text { et al. [131] }\end{array}$ & Diamond & $\mathrm{Ag}$ & NA & NA & EG & $0.005-0.1 \%$ & NA & 7 \\
\hline $\begin{array}{l}\text { Wole-Osho } \\
\text { et al. [132] }\end{array}$ & $\mathrm{Al}_{2} \mathrm{O}_{3}$ & $\mathrm{ZnO}_{2}$ & 29 & 70 & Water & $0.3-1.67 \%$ & $\begin{array}{l}\text { Correlation/ } \\
\text { ANFIS/ } \\
\text { ANN }\end{array}$ & 40 \\
\hline $\begin{array}{l}\text { Ahmed et al. } \\
\text { [133] }\end{array}$ & $\mathrm{ZnO}$ & $\mathrm{TiO}_{2}$ & 17 & 21 & Water & $0.1 \%$ & NA & 36 \\
\hline $\begin{array}{c}\text { Giwa et al. } \\
\text { [134] }\end{array}$ & $\mathrm{Al}_{2} \mathrm{O}_{3}$ & $\mathrm{Fe}_{2} \mathrm{O}_{3}$ & NA & NA & $\begin{array}{l}\text { DI water and } \\
\text { EG-DI } \\
\text { water }\end{array}$ & $0.05-0.75 \%$ & $\begin{array}{l}\text { ANFIS, } \\
\text { ANN, cor- } \\
\text { relation }\end{array}$ & $\begin{array}{l}1692.16 \% \text { and } \\
7618.89 \% \\
\text { for DI water } \\
\text { and EG- } \\
\text { DI water, } \\
\text { respectively }\end{array}$ \\
\hline $\begin{array}{l}\text { Pourrajab } \\
\text { et al. [135] }\end{array}$ & MWCNTs & $\mathrm{Ag}$ & NA & NA & Water & $0.20 \%$ & $\begin{array}{c}\text { Correlation } \\
\text { equation }\end{array}$ & 47.3 \\
\hline
\end{tabular}




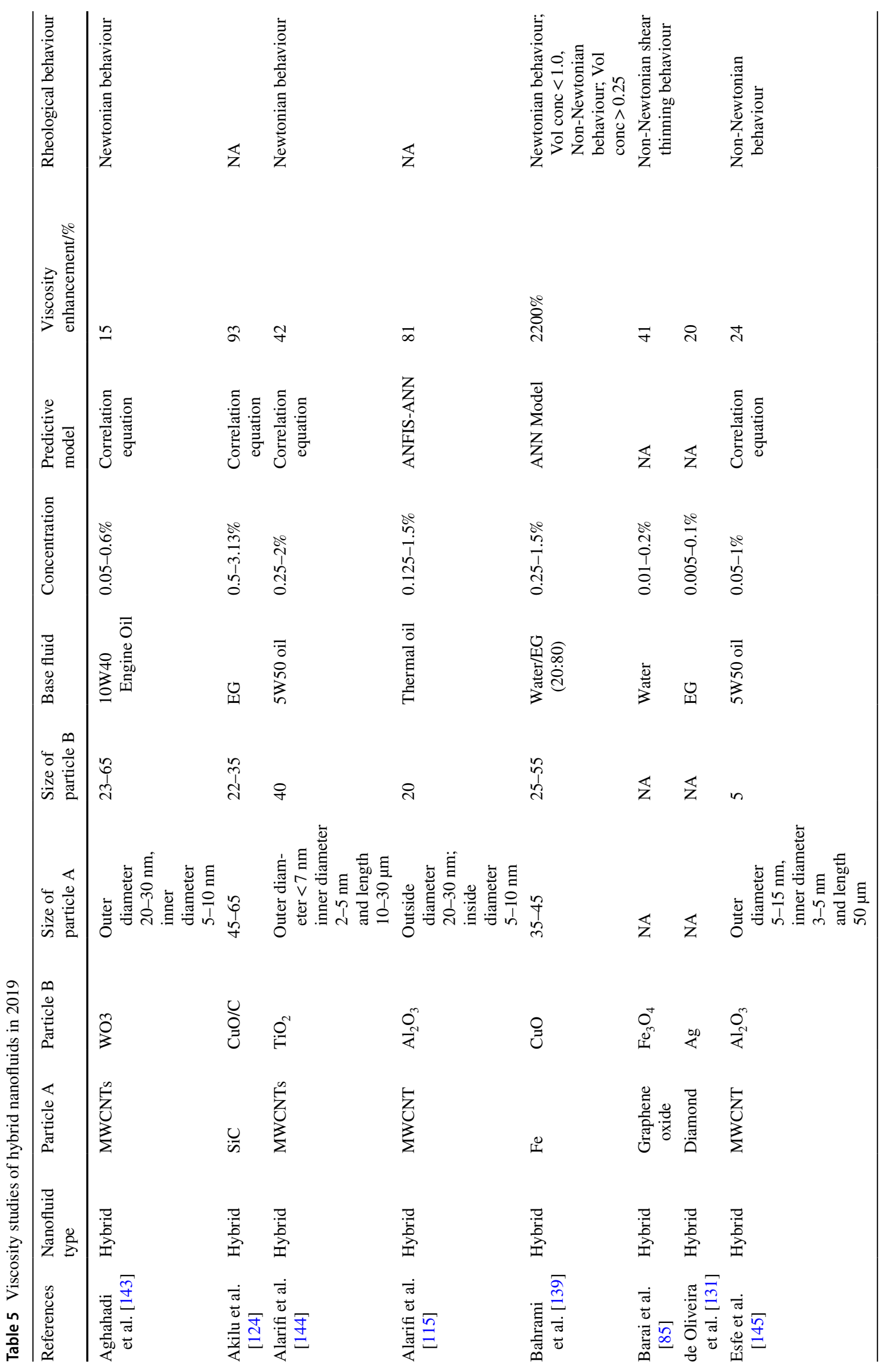




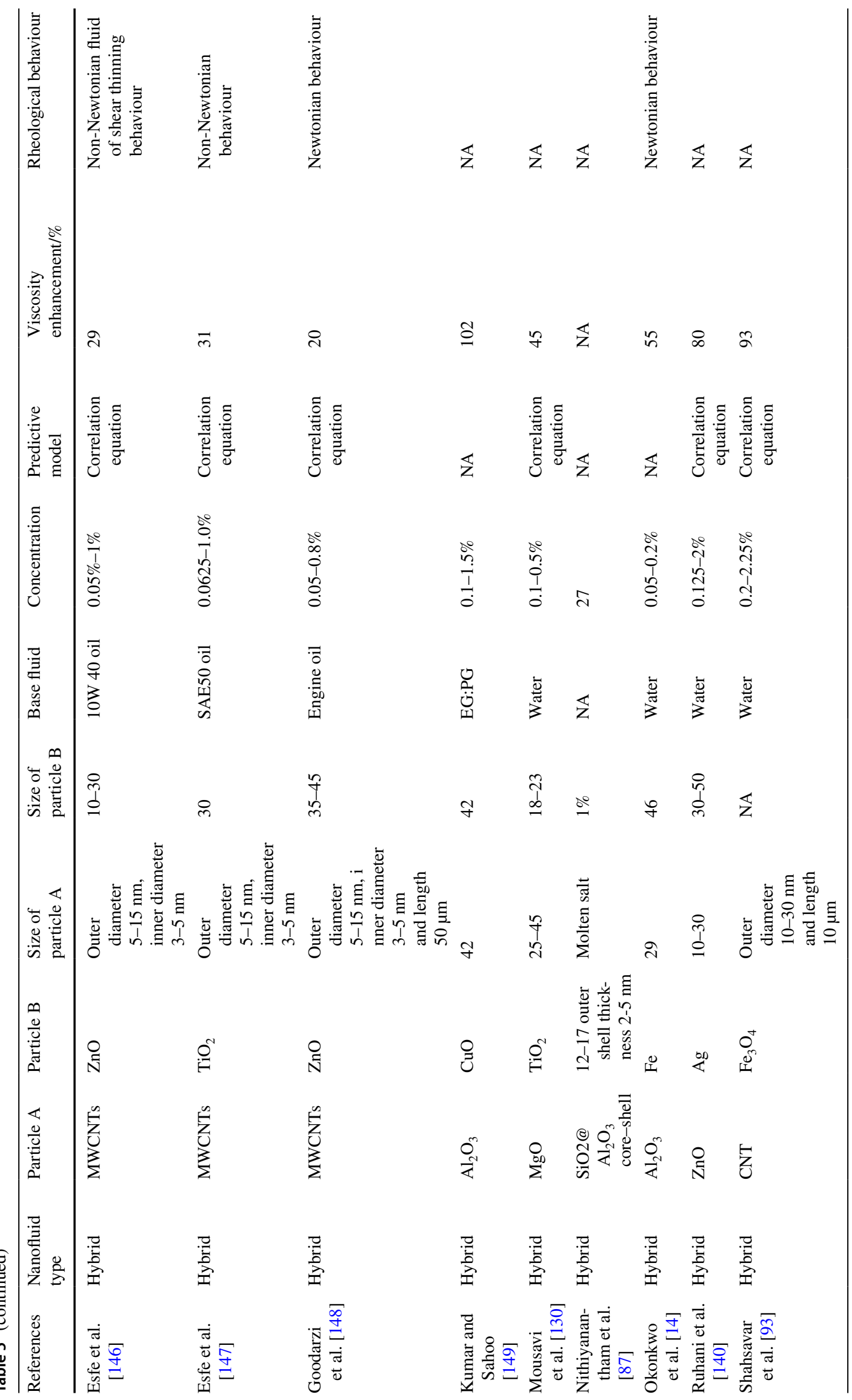




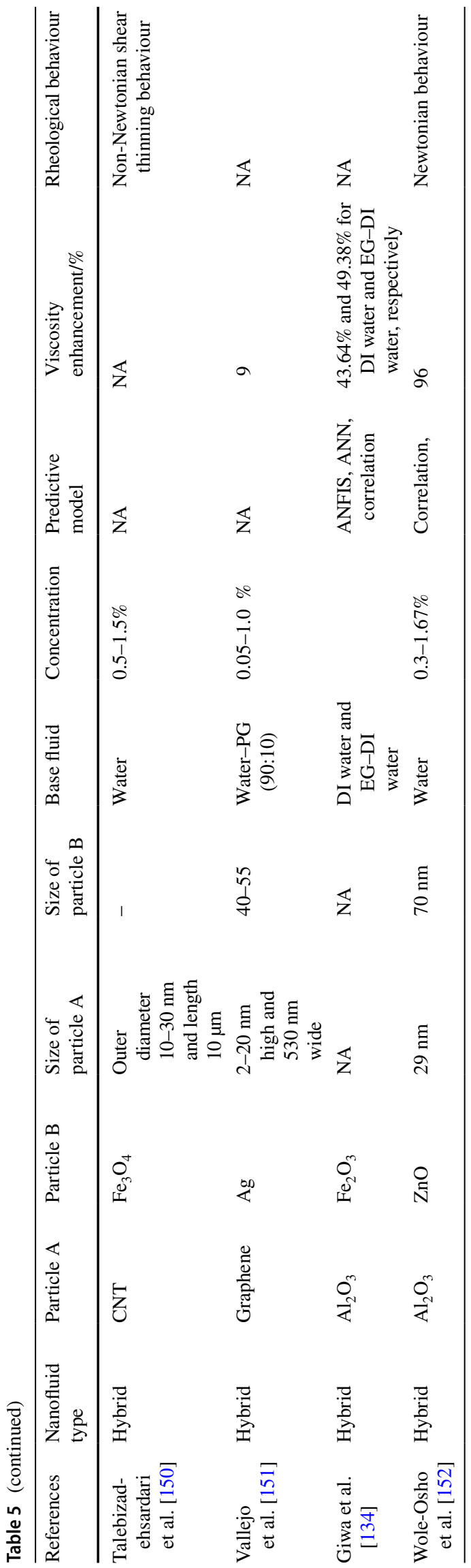

observed that the viscosity increased by $7.04 \%$ when volume concentration was $0.7 \%$. Hameed et al. [142] synthesised an eco-friendly MWCNTs-Kapok seed oil nanofluid using a one-step method, at a constant nanoparticle concentration of $0.1 \%$.

Considering all of the experimental viscosity measurements conducted, the relationship between viscosity and both temperature and particle concentration is apparent. Naturally, the viscosity of nanofluids increases with an increase in particle concentration, and this is observed in virtually all measured experiments. The viscosity of nanofluids decreases with an increase in temperature, and this is also observed in all measured experiments; this behaviour is expected as entropy is increased as particles gain thermal energy. However, the relationship between particle concentration and rheology is not as apparent. Considering the sample size alone as illustrated in Table 5, it can be observed that there exists no clear pattern between rheological behaviour and particle concentration in nanofluids. Rheological behaviour appears to vary from material to material.

\section{Specific heat of nanofluids}

The specific heat capacity of fluids is important in understanding both the heat transfer and the energy content of thermal systems. While significant research has focused on both viscosity and thermal conductivity, studies relating to the specific heat capacity of nanofluids are not as advanced. However, the specific heat capacity of fluid bears significance in thermal storage applications. Therefore, many studies regarding specific heat capacity often use molten salt as their base nanofluid. Moldoveanu and Minea [153] experimentally measured the specific heat of both $\mathrm{Al}_{2} \mathrm{O}_{3}-\mathrm{TiO}_{2}$ /water nanofluids and $\mathrm{Al}_{2} \mathrm{O}_{3}-\mathrm{SiO}_{2}$ /water nanofluids at volume concentration between 1 and 3.0\%. A correlation model was determined from the measured specific heat capacity values. It is important to note that the correlation model had an average deviation of $11 \%$ when compared to experimental specific heat values. However, when the mixture theory model was used to predict the nanofluids' specific heat capacity values, the deviation was as high as $19 \%$.

The effect of particle size and volume fraction on the specific heat of $\mathrm{SiO}_{2}$ molten salt nanofluid was investigated by $\mathrm{Li}$ et al. [154]. Using $\mathrm{SiO}_{2}$ nanoparticle with sizes of $10,20,30$ and $60 \mathrm{~nm}, \mathrm{SiO}_{2}$ molten salt nanofluid was synthesised at particle concentration between 0.5 and $2 \%$. Addition of particles to molten salt increases the specific heat capacity for all of the volume concentrations and particle sizes considered. An important point to note is that the particle concentration and particle size with the most specific heat enhancements were $1 \%$ and $20 \mathrm{~nm}$, respectively. 
Table 6 Some specific heat studies of nanofluids in 2019

\begin{tabular}{|c|c|c|c|c|c|c|c|c|}
\hline References & Nanofluid type & Particle A & Particle B & $\begin{array}{l}\text { Size particle } \\
\text { A/nm }\end{array}$ & $\begin{array}{l}\text { Size particle } \\
\text { B/nm }\end{array}$ & Base fluid & $\begin{array}{l}\text { Particle } \\
\text { concentration }\end{array}$ & $\begin{array}{l}\text { Predictive } \\
\text { model }\end{array}$ \\
\hline $\begin{array}{l}\text { Mousavi et al. } \\
\text { [130] }\end{array}$ & Hybrid & $\mathrm{MgO}$ & $\mathrm{TiO}_{2}$ & $25-45$ & $18-23$ & Water & $0.1-0.5$ vol $\%$ & $\begin{array}{c}\text { Correlation } \\
\text { equation }\end{array}$ \\
\hline $\begin{array}{l}\text { Okonkwo et al. } \\
\text { [14] }\end{array}$ & Hybrid & $\mathrm{Al}_{2} \mathrm{O}_{3}$ & $\mathrm{Fe}$ & 29 & 46 & Water & $0.05-0.2 \%$ & NA \\
\hline $\begin{array}{l}\text { Moldoveanu and } \\
\text { Minea [153] }\end{array}$ & Hybrid & $\mathrm{Al}_{2} \mathrm{O}_{3}$ & $\mathrm{TiO}_{2}$ & 45 & 30 & Water & $1-3.0 \%$ & $\begin{array}{c}\text { Correlation } \\
\text { equation }\end{array}$ \\
\hline $\begin{array}{l}\text { Moldoveanu and } \\
\text { Minea [153] }\end{array}$ & Hybrid & $\mathrm{Al}_{2} \mathrm{O}_{3}$ & $\mathrm{SiO}_{2}$ & 45 & 20 & Water & $1-3.0 \%$ & $\begin{array}{c}\text { Correlation } \\
\text { equation }\end{array}$ \\
\hline $\begin{array}{l}\text { Marcos et al. } \\
\text { [157] }\end{array}$ & Conventional & MWCNT & NA & $\begin{array}{l}\text { Outside diameter } \\
4-10 \mathrm{~nm} \text {, length } \\
60-100 \mathrm{~nm}\end{array}$ & NA & PEG400 & $0.01-1.0 \%$ & $\begin{array}{c}\text { Correlation } \\
\text { equation }\end{array}$ \\
\hline
\end{tabular}

Using $\mathrm{SiO}_{2}, \mathrm{Al}_{2} \mathrm{O}_{3}$ and $\mathrm{TiO}_{2}$ nanoparticles, three conventional nanofluids were synthesised by Hassan and Banerjee [155]. The study aimed to predict the specific heat capacity of metal oxide molten nitrate salt nanofluids using a multilayer perceptron neural network (MLP-ANN). The ANN model proposed was more accurate when compared to classical prediction methods [155]. Alade et al. [156] also considered a machine learning approach by applying a support vector regression model optimised with a Bayesian algorithm to predict the specific heat capacity of $\mathrm{Al}_{2} \mathrm{O}_{3}$ ethylene glycol nanofluids. The proposed model also exhibited a high degree of accuracy with the rootmean-square error (RMSE) equivalent to 0.0047 .

From Table 6, while the specific heat of molten salts increases with the addition nanoparticles, in experiments involving MWCNTs PEG 400 nanofluid, $\mathrm{Al}_{2} \mathrm{O}_{3}$-water nanofluid, Fe-water nanofluid and $\mathrm{Al}_{2} \mathrm{O}_{3}-\mathrm{Fe}$ nanofluid the specific heat of the base fluid exceeds that of the nanofluids.

\section{Factors affecting nanofluids stability and thermophysical properties}

The main factors affecting the thermophysical properties of nanofluids includes the morphology and concentration of nanoparticles, aggregation in the nanofluids and the sonication time used in its preparation [158]. The stability of nanoparticles suspended in a fluid is a very important parameter that affects both the rheological and thermophysical behaviours of the resultant nanofluids. Brownian motion causes the particles to collide with one another leading to cluster formation in the base fluid. These cluster formations or aggregation are controlled by a variety of internal forces between the base fluid and the nanoparticles such as the Van der Waals forces of attraction between the particles [159]. The aggregates begin to crystallise as their density exceeds that of the base fluid and affects the stability of the nanofluids over time [152]. Some of the factors that affect the stability of the nanofluids include the method of preparation of the nanofluids [66], agitation and sonication time [160-162], $\mathrm{pH}$ of the nanofluids [152], the addition of surfactants $[163,164]$ and surface charge density of the nanoparticles [158]. Asadi et al. [165] reviewed the effect of sonication on the stability and thermophysical properties of nanofluids. The study concluded that while there exists an optimum sonication time where thermal conductivity is maximum, and viscosity is least, more research is required to determine this optimum value, as it appears to differ for different nanofluids. Khan and Arasu [166] also reviewed the effects of nanoparticle synthesis techniques on the stability and thermophysical behaviour of nanofluids. The study importantly noted that there appears to be no standard method for stability measurements; this makes it difficult to compare stability across different papers. This is a problem because of the significant differences in reported fluid stability; this can range from days in some studies to months in others.

The values of the thermophysical properties of nanofluids are sensitive to the volume and size of nanoparticles used, the temperature of the mixture and the use of surfactants [167]. Yang et al. [168] investigated the thermal conductivity of graphene oxide/water nanofluids with a mass concentration range of $0-1.5 \%$. Their result showed that as the mass fraction of nanoparticles increased, the thermal conductivity enhancement increased. Also, at a $\mathrm{pH}$ of 8 , the nanofluids showed maximum stability with a maximum thermal conductivity enhancement of $48.1 \%$. This indicated that the $\mathrm{pH}$ was a significant parameter in both its stability and thermal conductivity. The authors attributed the thermal enhancement observed to the increased Brownian motion of particles and molecules of the base fluid as temperature increased. Yang et al. [169] also studied the thermal conductivity behaviour of zinc nanopowder in SAE 50 engine oil and recorded an increase in the thermal conductivity of the 
nanolubricant as the volume concentration of nanoparticles was increased. They recorded a maximum thermal conductivity enhancement of $8.74 \%$ and attributed this to the effects of increased Brownian motion of particles in the lubricant as temperature raises. The thermophoresis effect was another factor they highlighted that affected the thermal conductivity enhancement.

Rostami et al. [71] examined the thermal conductivity of $\mathrm{GO}-\mathrm{CuO}$ water/EG (50:50) hybrid nanofluid at a temperature of $25-50{ }^{\circ} \mathrm{C}$ and particle volume concentration of $0.1-1.6 \%$. Their investigation observes a $46 \%$ enhancement in thermal conductivity, which is higher than the enhancement of using single nanomaterial. Mahyari et al. [73] investigated the thermal conductivity $\mathrm{GO} / \mathrm{SiC}$ (50:50)/water hybrid nanofluid at volume concentrations between 0.05 and $1 \%$. Their investigation reveals that the effect of the volume concentration of nanoparticles was more significant than the effect of increasing temperature. Importantly, the studies observed that the enhancement in thermal conductivity of their hybrid nanofluid was more than the reported thermal conductivity enhancement using GO or SiC individually. Hybrid nanofluids not only affect the thermal conductivity, but also enhance the stability of nanofluids.

\section{Heat transfer mechanisms of nanofluids}

The main benefit of using nanofluids is their enhanced thermal transport which results in improvements in the thermal conductivity of traditional heat transfer fluids. As previously outlined, several parameters influence the thermal conductivity enhancement and include nanoparticle type, nanoparticles size, nanoparticles concentration, temperature, type of base fluid and the thermophysical properties of both the base fluid and the nanoparticles. Over the last three decades, since the introduction of nanofluids in 1995, the explanations behind the enhanced heat transfer of nanofluids have been attributed to several mechanisms. The size and the large number of particles interacting with the base fluid present a challenge to properly understanding the nanoscale effects that support the improved thermal properties observed in the literature. Mahian et al. [108, 170] studied the mechanisms that would aid the simulation of nanofluids flow. They highlighted that forces such as drag, lift, Brownian motion, thermophoresis, Van der Waals and electrostatic double-layer forces had a significant effect on the thermal and rheological behaviours of nanofluids.

Brownian motion is defined as the uncontrollable random motion of particles within the fluid due to the collision between slow moving and higher velocity particles. Brownian motion occurs as a result of thermal diffusion, and this phenomenon is increased at higher temperatures, low viscosity and smaller particle size. As promoted by the scientific community, the random collision of particles within the fluid remains the primary reason for the thermal conductivity enhancement observed with nanofluids $[73,79,92]$. However, Jang and Choi [171] provided three types of collisions that occur due to the rising temperature of nanofluids: collisions between the molecules of the base fluid, collisions between base fluid molecules and the nanoparticles, and the collisions between nanoparticles due to Brownian motion. They concluded that the effect of Brownian motion on thermal conductivity enhancement had the least effect among the three types of collisions.

Keblinski et al. [172] was the first to introduce the idea of nanolayers and their effect in nanofluid thermophysical behaviour. The nanolayer is known as the solid-like structure or the interfacial layer between the solid surface and the first layer of the fluid in contact with the solid surface. A structured, layered arrangement of the fluid molecules around the surface of the nanoparticles was observed. These layers behaved like solids and act as a thermal bridge for the heat transfer process enhancing the overall thermal conductivity of the fluid. In the solid-solid interface, this layer acts as a barrier of heat transfer due to incomplete contact between solid surfaces. However, it is not the case for the solid-liquid interface as the aligned interfacial shell in the nanoparticle suspension would make heat transfer across the interface effective. Yu and Choi [173] presented a modified Maxwell model to account for the effect of nanolayers on the thermal conductivity of nanofluids. Their results proved that the thermal model is enhanced as a result of accounting for this factor. Xie et al. [174] investigated the effect of the nanolayer on the effective thermal conductivity of nanoparticle-fluid mixtures. It was observed that the effective thermal conductivity increases with a decrease in particle size and an increase in nanolayer thickness. It was concluded that manipulating the nanolayer structure might be an effective method to produce higher thermally conductive nanofluids.

Another factor responsible for nanofluid thermophysical behaviour is the "particle nanoclusters". It should be noted that nanoparticles have strong Van der Waals interactions that force them to form nanoclusters, which lead to a rich zone of high thermal conductive nanoparticles that improve the bulk thermal conductivity of the fluid. However, increasing the size and mass of nanoclusters will result in nanoparticle sedimentation, which will eliminate its effect on thermal conductivity. Keblinski et al. [172] also suggest that at high loading of nanoparticles, the effect of nanoclusters was promoted due to an increase in Van der Waal's force of attraction among the nanoparticles.

The effect of the diffusive/ballistic nature of heat transport and thermophoresis has been reported [172]. Thermophoresis is related to thermal diffusion due to the temperature gradient. It describes the movement of the nanoparticles due to the temperature gradient from the high-temperature zone to 
a lower-temperature zone which could influence the thermal conductivity. Thermophoresis is different from Brownian motion as the whole movement in thermophoresis is onedirectional. The diffusive/ballistic nature of heat transport is an explanation for the heat transfer in crystalline solids. In solid media such as the nanoparticles used in nanofluids, the heat is transported by phonons. The thermal conductivity is significantly enhanced if a particle was influenced by a phonon that is created in another nearby particle that exists in the same liquid. This is because the mean free path of the phonon is shorter in the liquid than it is in the particles. However, the effect of Brownian motion, nanolayer and nanoclusters on thermal conductivity enhancement is more significant and the reasons mostly reported by the authors in 2019. These mechanisms have all been discussed in greater detail in review studies on heat transfer mechanisms in nanofluids [175-179].

\section{Application of nanofluids in various thermal devices}

\section{Nanofluids in solar thermal collectors}

Solar collectors are used in converting the radiant energy of the Sun to thermal or electrical energy, benefiting from radiative, convective and conductive heat transfer principles. The solar irradiance from the sun is absorbed by the collector with the aid of a working fluid flowing within its absorber. The common fluids used for thermal energy absorption are water, oils, ethylene glycol (EG) and salts. These working fluids have limitations that affect the overall efficiencies of various collectors. Their main limitation is in its low thermal conductivity. To obtain higher thermal conductivity, nanofluids have been proposed and tested for use in the various solar collectors. This section reviews the progress in the application of nanofluids in various solar collectors. Figure 4 presents a classification of different solar collectors that can use nanofluids as heat transfer fluids.

\section{Flat plate collector (FPC)}

The flat plate collector is the most widely used solar collectors. It is a rectangular tray consisting of an absorber surface (plate) with copper tubes (raiser) positioned along its surface. An insulating material placed at the backside helps reduce heat loss due to conduction, and a glass or transparent glazing over the top of the collector helps minimise radiative and convective heat losses. Figure 5 presents a schematic representation of the flat plate collector. To enhance

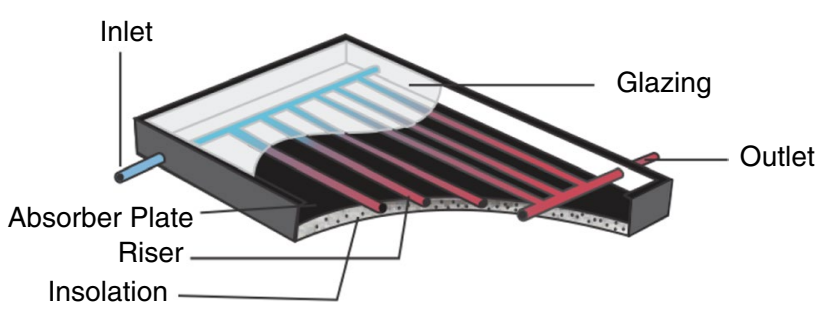

Fig. 5 Schematic of flat plate solar collector

Fig. 4 Classification of solar collectors where nanofluids can be applied

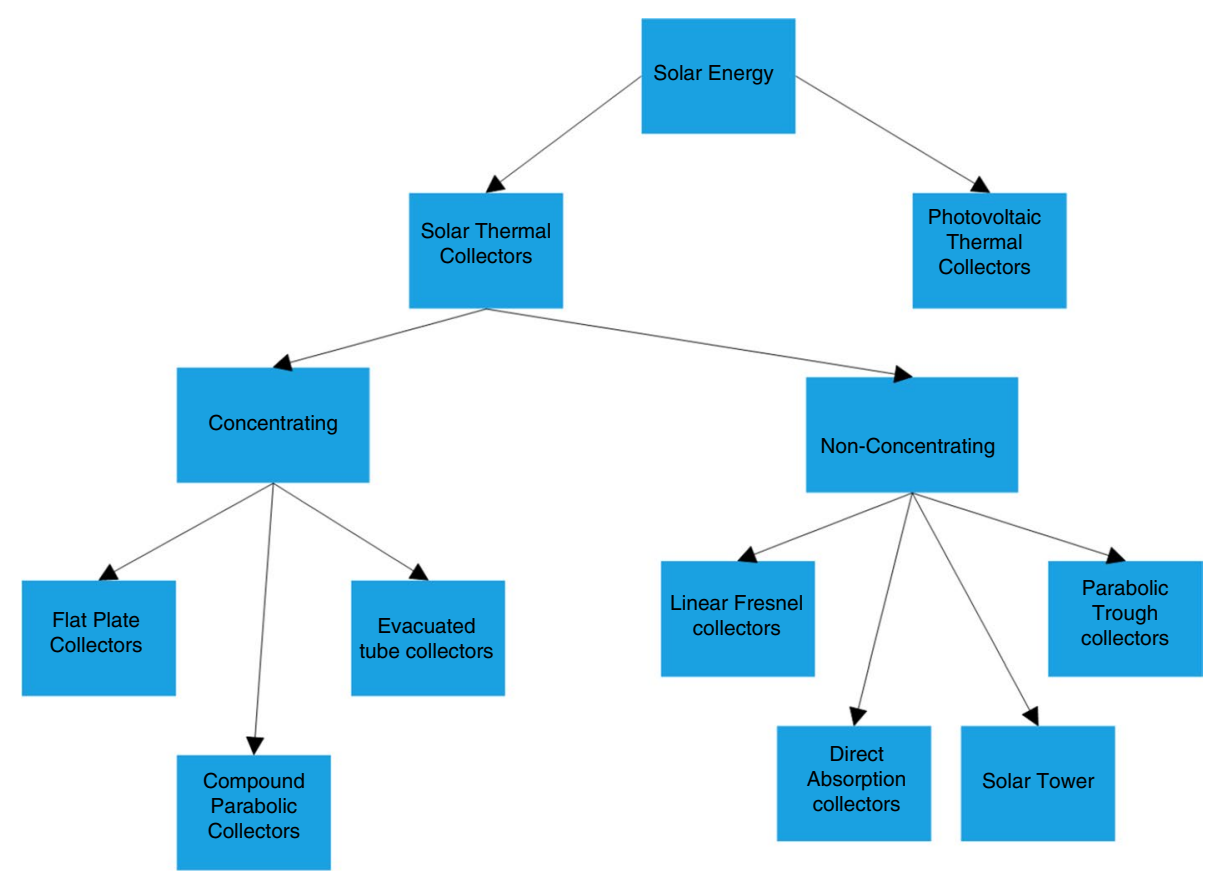


the efficiency of the collector, conventional fluids have been replaced with nanofluids. For instance, Choudhary et al. [180] investigated the stability of $\mathrm{MgO}$ nanofluids for use in a flat plate solar collector, considering the effect of volumetric concentrations between 0.08 and $0.4 \%$ on the stability of the nanofluid over time. The study demonstrated that the nanofluids achieved better stability at $0.04 \%$ volumetric concentration. Upon testing the nanofluids in the flat plate collector, the maximum thermal efficiency of $69.1 \%$ was achieved at a $0.2 \%$ volumetric concentration and 1.5 lit $\min ^{-1}$. This value represents a $16.36 \%$ enhancement in thermal efficiency when compared to EG/water.

Ahmadlouydarab et al. [181] investigated the thermal absorption ability and the overall thermal efficiency of a flat plate collector using $\mathrm{TiO}_{2}$-water nanofluids as an agent fluid in the outer part of the absorber of a flat plate collector. In this design, the nanofluids act as thermal insulation by utilising the high thermal capacity of these fluids. Furthermore, the $\mathrm{TiO}_{2}$ nanoparticle was used on the outer part of the glass cover of the collector to enhance the self-cleaning properties of the glass surface. The study concluded that the new system design enhanced the thermal efficiency of the collector by $49 \%$ at a $5 \%$ nanoparticle volumetric concentration.

Saffarian et al. [182] using $\mathrm{Al}_{2} \mathrm{O}_{3}$ and $\mathrm{CuO}$-water nanofluids investigated the effect of a change in the flow direction of the flat plate collector using modified U-shape, spiral and wavy pipes. The study demonstrates that the heat transfer coefficient increased by using nanofluids instead of water. The wavy and spiral geometries significantly improved the heat transfer; however, higher pressure losses were witnessed with the use of the wavy pipe. The study concluded that the use of the wavy pipes along with $\mathrm{CuO}$ nanofluids at $4 \%$ volume concentration increased the heat transfer coefficient by $78.25 \%$.

Tong et al. [183] experimentally analysed the thermal performance of a flat plate collector using $\mathrm{Al}_{2} \mathrm{O}_{3}$ and $\mathrm{CuO}$ nanofluids. It was demonstrated that with a $1 \%$ volume concentration of $\mathrm{Al}_{2} \mathrm{O}_{3}$, the highest thermal efficiency enhancement of $21.9 \%$ was achieved. Furthermore, exergy efficiency enhancements of $56.9 \%$ and $49.6 \%$ were recorded when compared to water using $\mathrm{Al}_{2} \mathrm{O}_{3}$ at $1 \mathrm{Vol} \%$ and $\mathrm{CuO}$ at $0.5 \mathrm{Vol} \%$, respectively.

Mondragon et al. [184] tested the performance of a flat plate collector under laminar flow conditions using $\mathrm{Al}_{2} \mathrm{O}_{3}$-water nanofluids. The study demonstrated that at a $1 \%$ volume concentration of $\mathrm{Al}_{2} \mathrm{O}_{3}$ in the nanofluids, a $2.3 \%$ increase in heat transfer coefficient could be theoretically attained. However, when testing for the collector efficiency, the study observed a decrease in the collector's efficiency from $47 \%$ using water to $41.5 \%$ when using the $\mathrm{Al}_{2} \mathrm{O}_{3}$-water nanofluids. The decrease was attributed to the formation of nanoparticle deposition layers on the absorber tube; these layers acted as an additional form of resistance to heat transfer. The authors attributed the formation of these layers to the low flow velocity of the nanofluids.

\section{Evacuated tube solar collector (ETSC)}

This type of collector is more efficient than the flat plate collectors as heat losses in the ETSC are reduced when compared to the FPC due to the presence of vacuum insulation. A vacuum between the glass tube and the evacuated tube heat pipe helps to reduce losses due to convection and conduction. The heat pipe within the tube contains an antifreeze liquid in a closed system. This pipe then extends into the manifold where the liquid flowing in the manifold condenses the antifreeze and is then returned to be heated by the heat pipe. A pictorial depiction of this collector is shown in Fig. 6.

The use of nanofluids to enhance the performance of this collector has been investigated. For instance, Sarafraz et al. [185] evaluated the performance of an evacuated tube solar collector working with a carbon acetone mix in the heat pipe. The results demonstrate that the thermal efficiency of $91 \%$ was achieved, which is above that of the average thermal efficiency of $72.6 \%$ when using acetone alone.

Natividade et al. [186] experimentally evaluated an ETSC using multilayer graphene (MLG)-based water nanofluids. The ETSC was equipped with parabolic concentrators. The MLG at concentrations of $0.00045 \mathrm{Vol} \%$ and $0.00068 \mathrm{Vol} \%$ increased the thermal efficiency of the collector by $31 \%$ and $76 \%$, respectively, when compared to the base fluid. Sadeghi et al. [187] also used a parabolic concentrator to enhance the performance of an ETSC operating with $\mathrm{Cu}_{2} \mathrm{O}$-water nanofluid. The experimental set-up was verified using an ANN multilayer perception model. The maximum thermal efficiency of $60 \%$ was attained at a flow rate of 50 litres/hour and $0.08 \mathrm{Vol} \%$ of $\mathrm{Cu}_{2} \mathrm{O}$. This value represented an $87.5 \%$ enhancement in the collector's performance when compared to water.

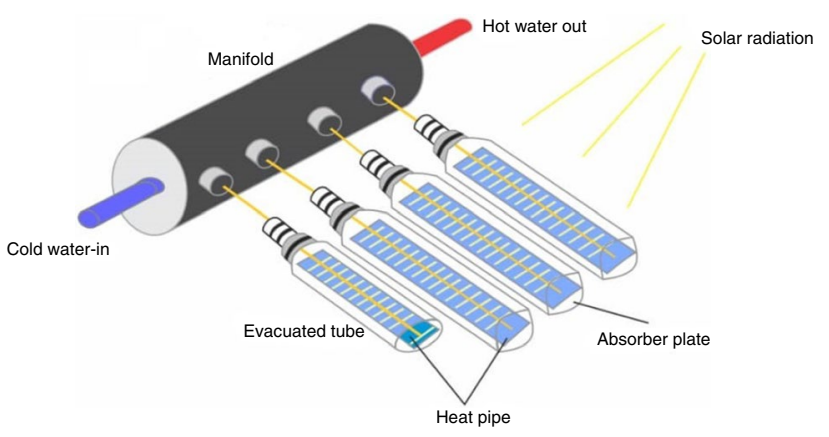

Fig. 6 Schematic diagram of an evacuated tube solar collector 


\section{Compound parabolic collectors (CPC)}

CPCs are similar to flat plate collectors but have parabolic optics attached to each tube, which concentrates incident solar radiation onto the absorbers. Similar to flat plate and evacuated tube collectors, CPCs can be static while collecting diffuse solar radiation. There are four kinds of CPCs: flat one-sided absorbers, flat two-sided absorbers, wedgelike absorbers and tubular absorbers as shown in Fig. 7. A tubular absorber contains a parabolic collector surface and an absorber tube. Korres et al. [188] investigated nanofluids-based CPC under laminar flow regime. The study demonstrated a mean and maximum heat transfer coefficient enhancement of $16.16 \%$ and $17.41 \%$, respectively. Factoring in the effect of pressure losses as a result of using nanofluids, the study concluded that the pressure drops observed were not a limitation to the use of the nanofluids and recorded a thermal efficiency enhancement of $2.76 \%$ when using $\mathrm{CuO} /$ Syltherm nanofluids.

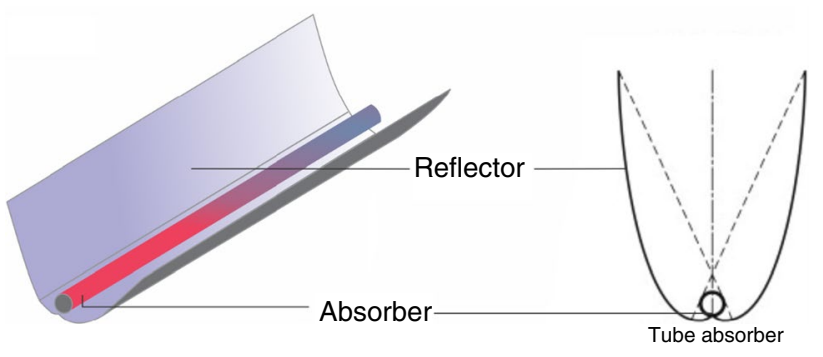

Fig. 7 Cross section of CPC tubular absorber

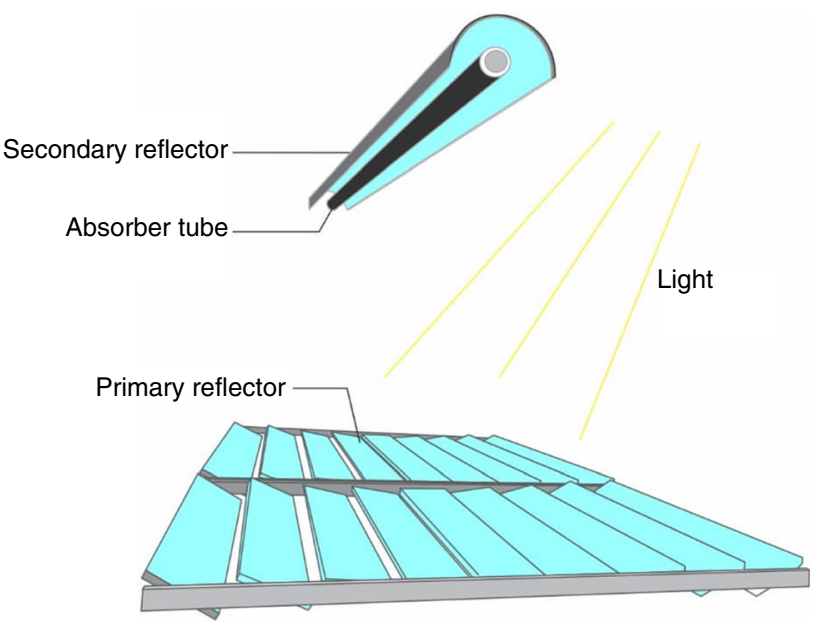

Fig. 8 Diagram of a linear Fresnel reflector

\section{Linear Fresnel reflectors (LFR)}

A linear Fresnel reflector is a concentrating solar collector characterised by its ease of assembly; this makes it cheaper when compared to other concentrating solar collectors. As shown in Fig. 8, the LFR utilises mirrors whose orientation revolves around a pivot following the Sun in other to concentrate its rays towards the absorber tube [189]. This system can produce thermal energy for medium- to high-temperature applications. However, LFRs are not as widely installed collectors; therefore, there are not as many studies applying the collector with nanofluids. Ghodbane et al. [190] performed a study to assess the performance of MWCNT-water nanofluid in the LFR. The outcomes indicate that MWCNT at $0.3 \mathrm{Vol} \%$ resulted in a more favourable thermal efficiency of $33.81 \%$ when compared to other fluids tested and resulted in the highest pressure loss of 2.3-46 Pa. The use of the nanofluids also demonstrated a reduction in the rate of entropy generation within the system.

\section{Parabolic trough solar collectors (PTSC)}

Parabolic trough solar collectors are the most commercially deployed and studied concentrating solar collectors available. As depicted in Fig. 9, the collector utilises a parabolashaped mirror to reflect the solar radiation from the Sun onto a cylindrical receiver. The receiver comprises a concentric absorber tube enveloped with a glass cover. Solar radiation absorbed by the receiver is transferred to the working fluid passing through it, and it is then transported to applications requiring medium to high temperatures $\left(50{ }^{\circ} \mathrm{C}-400{ }^{\circ} \mathrm{C}\right)$. Okonkwo et al. [191] synthesised zero-valent iron and $\mathrm{TiO}_{2}$

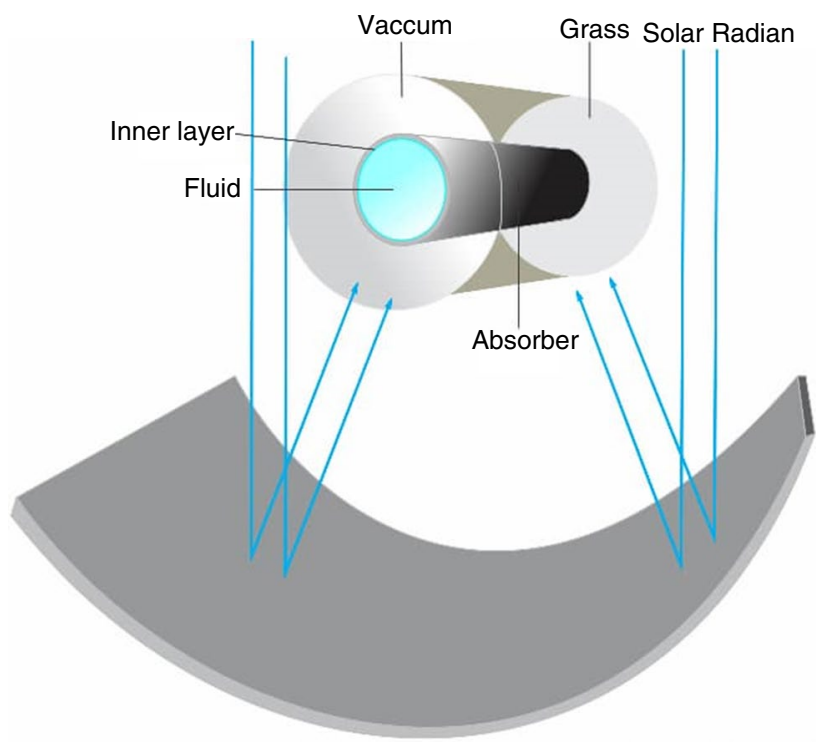

Fig. 9 Schematic of a parabolic trough solar collector 


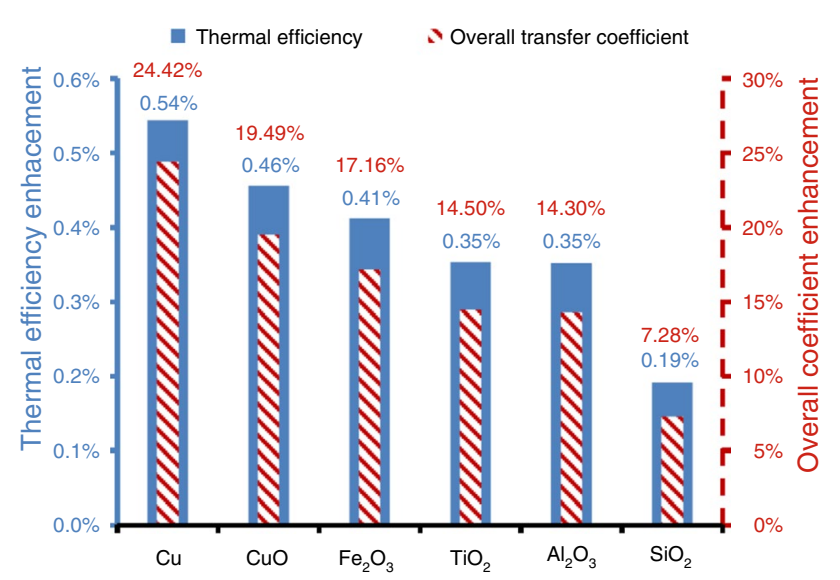

Fig. 10 Thermal efficiency and overall heat transfer coefficient enhancement at 4 vol\% [194]

nanoparticles from olive leaf extracts for use in a solar parabolic trough collector. The nanoparticles were used to prepare nanofluids with Syltherm-800 as base fluid. The use of Syltherm-800/TiO ${ }_{2}$ and Syltherm-800/ZVI produced a $42.9 \%$ and $51.2 \%$ enhancement in the heat transfer coefficient at a $3 \%$ nanoparticle volume concentration. Although the use of the nanofluids resulted in an $11.5 \%$ drop in pressure, the authors stated that a thermal efficiency enhancement of $0.51 \%$ and $0.48 \%$ was still achieved while using Syltherm-800/ZVI and Syltherm-800/ $/ \mathrm{TiO}_{2}$ nanofluids, respectively. Ehyaei et al. [192] examined the energy, exergy and economic analysis of a PTSC operating with water and Therminol VP1 as working fluids. These fluids were also used as base fluid with the addition of $\mathrm{CuO}$ and $\mathrm{Al}_{2} \mathrm{O}_{3}$ nanoparticles. The annual efficiency of the PTSC was taken with all four working fluids, and the results indicate that the annual energy and exergy efficiency of water was $10.64 \%$ and $9.07 \%$, while the addition of $\mathrm{Al}_{2} \mathrm{O}_{3}$ and $\mathrm{CuO}$ in water at $5 \%$ volume concentration only increased the efficiency of the PTSC by $0.03 \%$ and $0.09 \%$, respectively.

Malekan et al. [193] investigated the heat transfer in a PTSC working with $\mathrm{Fe}_{3} \mathrm{O}_{4}$ and $\mathrm{CuO} /$ Therminol-66 nanofluids under an external magnetic field. The results demonstrated that by increasing the nanoparticle concentration, the heat transfer in the collector was enhanced. The maximum heat transfer enhancement observed in $\mathrm{Fe}_{3} \mathrm{O}_{4} /$ Therminol-66 nanofluids was at $4 \%$ volume concentration and nanoparticle size of $10 \mathrm{~nm}$. The presence of a magnetic field enhanced the performance of $\mathrm{Fe}_{3} \mathrm{O}_{4} /$ Therminol-66 more than that of $\mathrm{CuO} /$ Therminol-66 nanofluid although the $\mathrm{CuO}$ nanoparticles had a better thermal conductivity.

Bellos and Tzivanidis [194] evaluated the performance of an LS-2 collector with six different nanoparticles $(\mathrm{Cu}, \mathrm{CuO}$,
$\mathrm{Fe}_{2} \mathrm{O}_{3}, \mathrm{TiO}_{2}, \mathrm{Al}_{2} \mathrm{O}_{3}$ and $\mathrm{SiO}_{2}$ ) using Syltherm- 800 as base fluid. The nanoparticle concentration was varied up to $6 \%$, and their result showed that $\mathrm{SiO}_{2}$ nanoparticle provided the least enhancement in thermal efficiency with $0.19 \%$, while $\mathrm{Cu}$ with $0.54 \%$ provided the highest enhancement at a $4 \%$ volume concentration as shown in Fig. 10. Other nanoparticles $\mathrm{CuO}, \mathrm{Fe}_{2} \mathrm{O}_{3}, \mathrm{TiO}_{2}$ and $\mathrm{Al}_{2} \mathrm{O}_{3}$ had an enhancement of $0.46 \%, 0.41 \%, 0.35 \%$ and $0.25 \%$, respectively.

\section{Direct absorption solar collector}

The direct absorption solar collector (DASC) is a concentrating solar collector with fewer thermal resistance when compared to regular solar collectors. By removing the absorbing surface, the working fluid can absorb solar radiation directly. As illustrated in Fig. 11, the conductive and convective resistance as a result of the use of a surface absorber is eliminated, making the efficiency of the system dependent on the absorptivity and thermal properties of the working fluid. This modification reduces the thermal losses in the system.

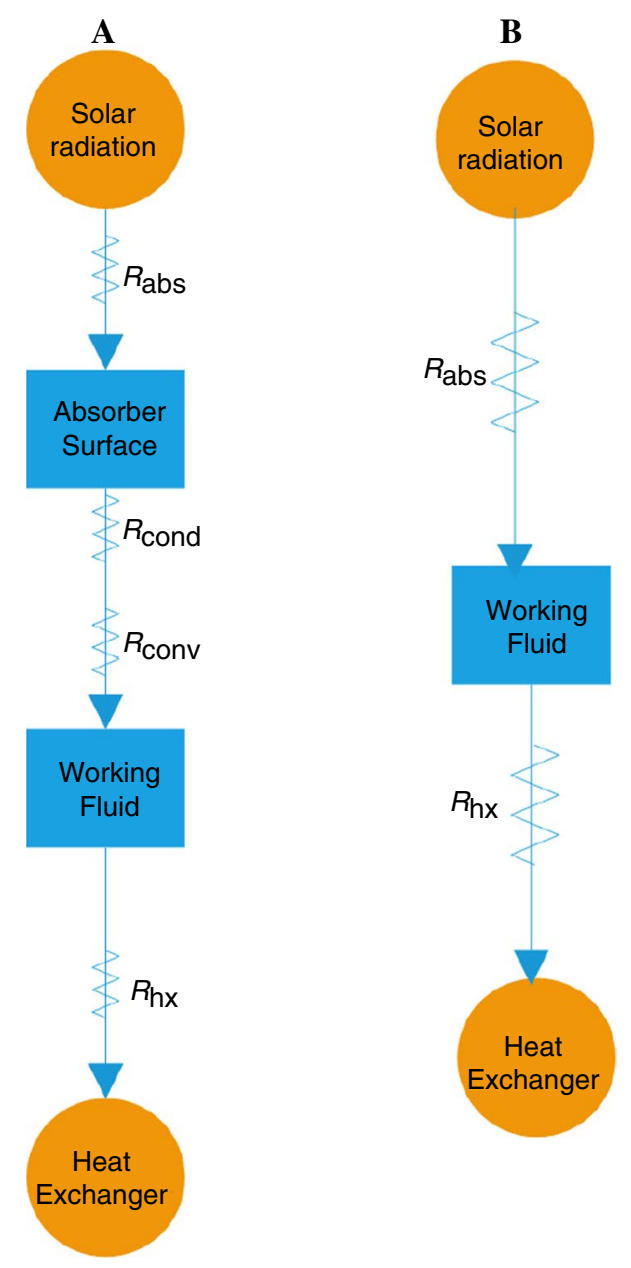

Fig. 11 Thermal resistance network for a regular solar collector, b direct absorption collectors 
Qin et al. [195] stated that the direct absorption solar collectors are 5-10\% more efficient than the regular parabolic trough collector. However, the challenge with these systems remains the low absorption properties of the working fluids. The use of nanoparticles dispersed in these working fluids can, however, improve the performance of the collector [30]. Tafarroj et al. [196] investigated the use of $\mathrm{SiO}_{2} / \mathrm{EG}$ and MWCNT/EG nanofluids in a direct absorption solar collector. The outcomes suggest that at $0.6 \%$ volume concentration of nanoparticles, MWCNT/EG nanofluids provided the highest outlet temperature of $346.1 \mathrm{~K}$. Simonetti et al. [197] performed a CFD study on direct volumetric absorption solar collector operating with SWCNT/EG nanofluids and compared its performance with a DASC integrated with a compound parabolic collector. The study concluded that the DASC performed better than the direct volumetric absorption solar collector.

\section{Photovoltaic thermal collectors (PVT)}

The cells of photovoltaic (PV) systems are affected negatively by high temperatures $\left(25^{\circ} \mathrm{C}\right)$, as the excess heat received from the Sun reduces the efficiency of the PV module. Technologies such as the hybrid PVT system have been developed to extract this heat for possible utilisation in other thermal applications, while also enhancing the electrical output of the PV module. Evident from Fig. 12, the excess heat

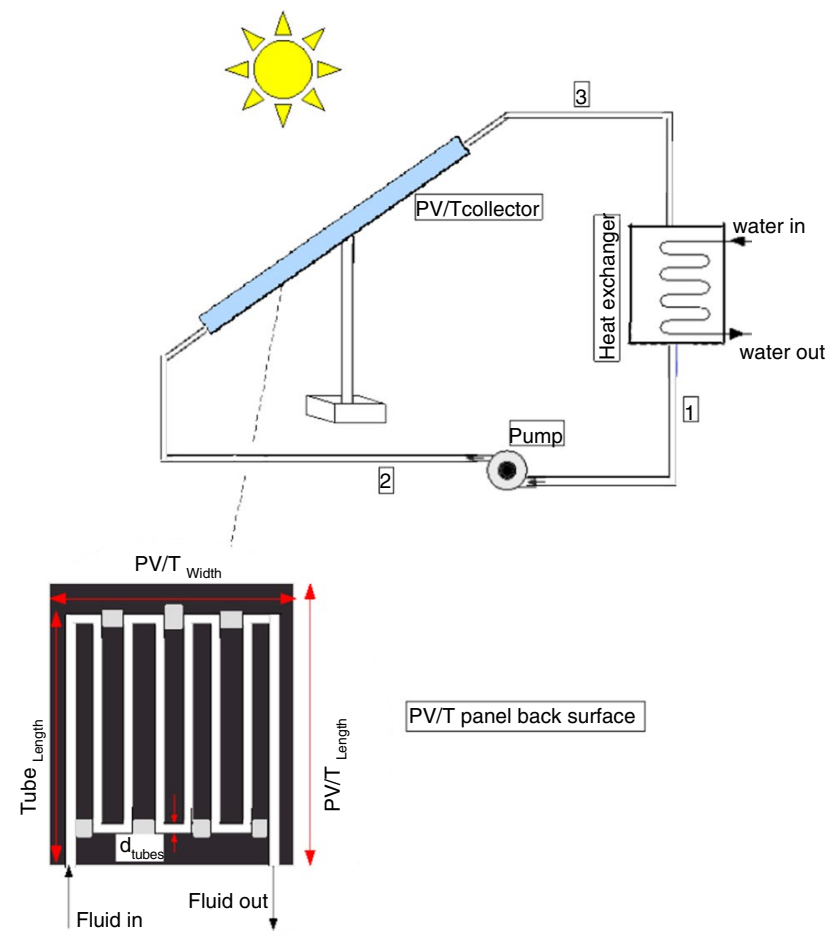

absorbed by the cells is transferred to a heat transfer fluid which cools the collector and provides heat for use in other thermal applications.

Sangeetha et al. [198] experimented to determine the performance of a hybrid PVT system utilising different nanoparticles dispersed in water. The study evaluated the performance of MWCNT, $\mathrm{Al}_{2} \mathrm{O}_{3}$ and $\mathrm{CuO}$ in water and demonstrated that nanofluids improved the electrical efficiency of the PVT when compared to water. The use of MWCNT and $\mathrm{CuO}$ nanofluids decreased cell temperature by $19 \%$. MWCNT, $\mathrm{Al}_{2} \mathrm{O}_{3}$ and $\mathrm{CuO}$ nanofluids enhanced the electrical efficiency of the PV by $60 \%, 55 \%$ and $52 \%$, respectively. Similarly, Alous et al. [199] investigated the performance of MWCNT and graphene nanoplatelets (GNPs) dispersed in water as coolant in a PVT system. The study concluded that the addition of the thermal module improved the exergetic efficiency of the system by $53.4 \%$ using water, $57.2 \%$ using MWCNT-water and $63.1 \%$ using GNP-water. An $18.6 \%$ enhancement in energy efficiency was recorded with the use of GNP-water nanofluids in the PVT collector. This represented the highest observed enhancement in energy efficiency in their study. Fudholi et al. [200], on the other hand, examined the use of $\mathrm{TiO}_{2}$ water nanofluids on a PVT. The study concluded that at a mass concentration of $1 \%$, the $\mathrm{TiO}_{2}$ nanofluid recorded an $85-89 \%$ performance enhancement when compared to water with $60-76 \%$ at a mass flow rate of $0.0255 \mathrm{~kg} / \mathrm{s}$. Abdelrazik et al. [201] studied the effect of optical filtration along with nano-enhanced phase change materials (PCMs) on the performance of a PVT collector, demonstrating that optical filtration, and the use of nano-PCM, increased the overall efficiency of the collector by $6-12 \%$. A combined PVT/PCM system using nanofluids has proved to be an effective coolant in enhancing the thermal conductivity of PVT collectors [202]. Other studies related to nanofluids in solar collectors investigated the photothermal properties of various mono and hybrid nanofluids [203-212], the impact of magnetic fields on the thermal performance of nanofluids in a solar collector [213], the forced convective behaviour of nanoparticles inside a solar collector [214] and more recently the application of ANN models for the prediction of nanofluids performance in solar collectors [215-217]. Other studies investigating the application of nanofluids in various solar collectors are presented in Table 7.

\section{Nanofluids in heat exchangers}

Heat exchangers (HX) are devices used for the transfer of heat between two or more fluids. The use of nanofluids in the different kinds of heat exchangers has been investigated and discussed below.

Fig. 12 Hybrid nanofluid-cooled PVT 


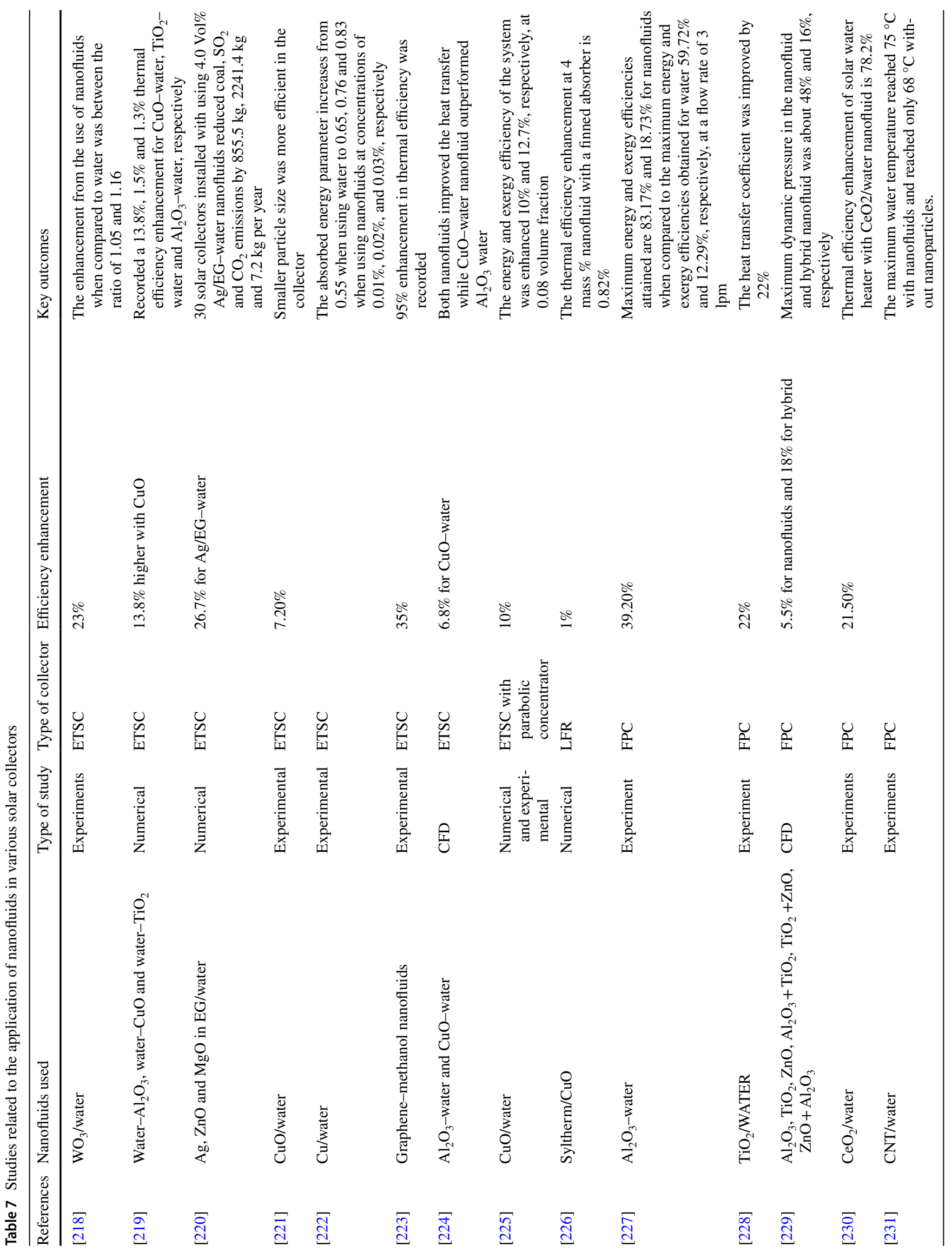




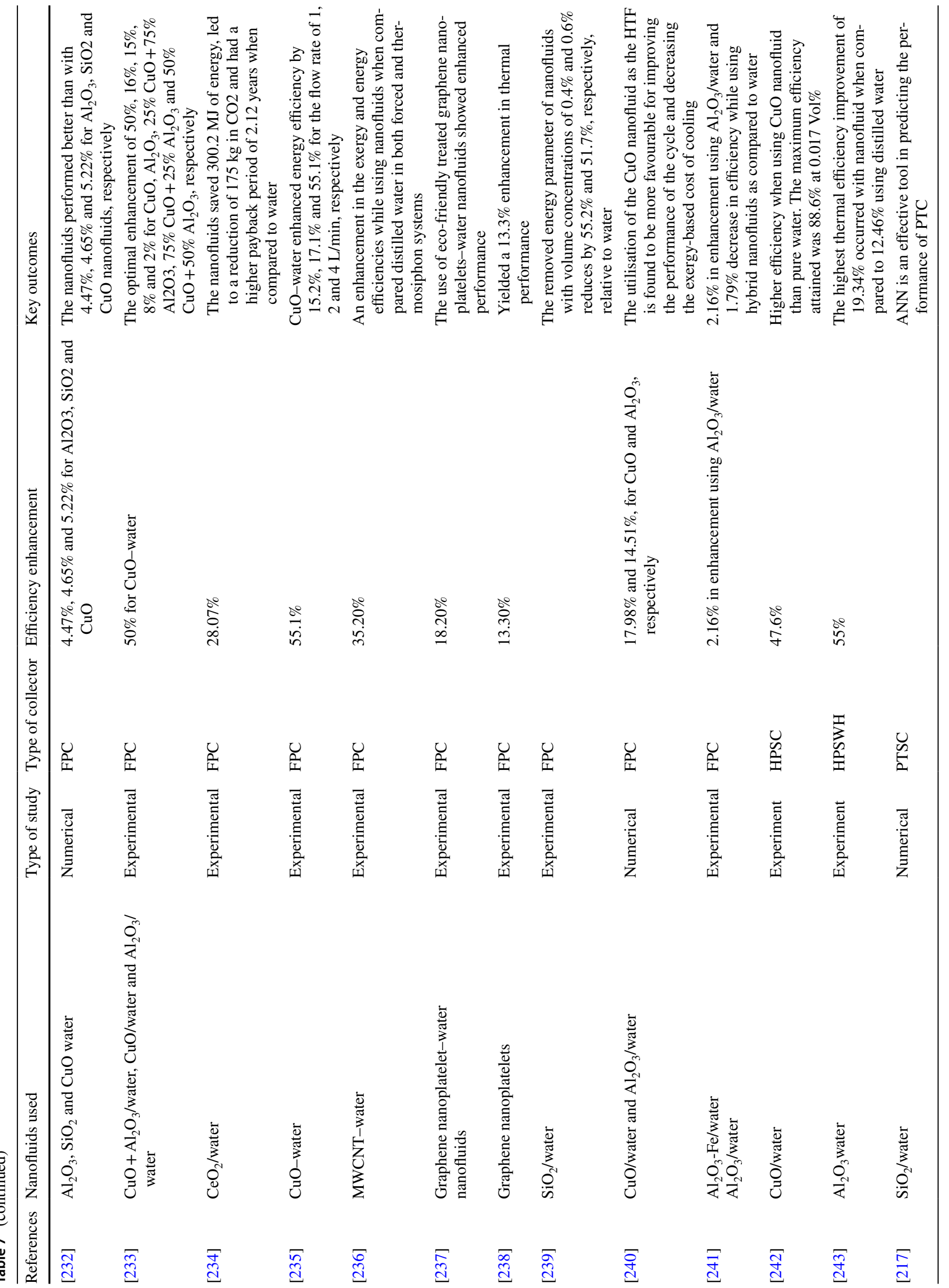




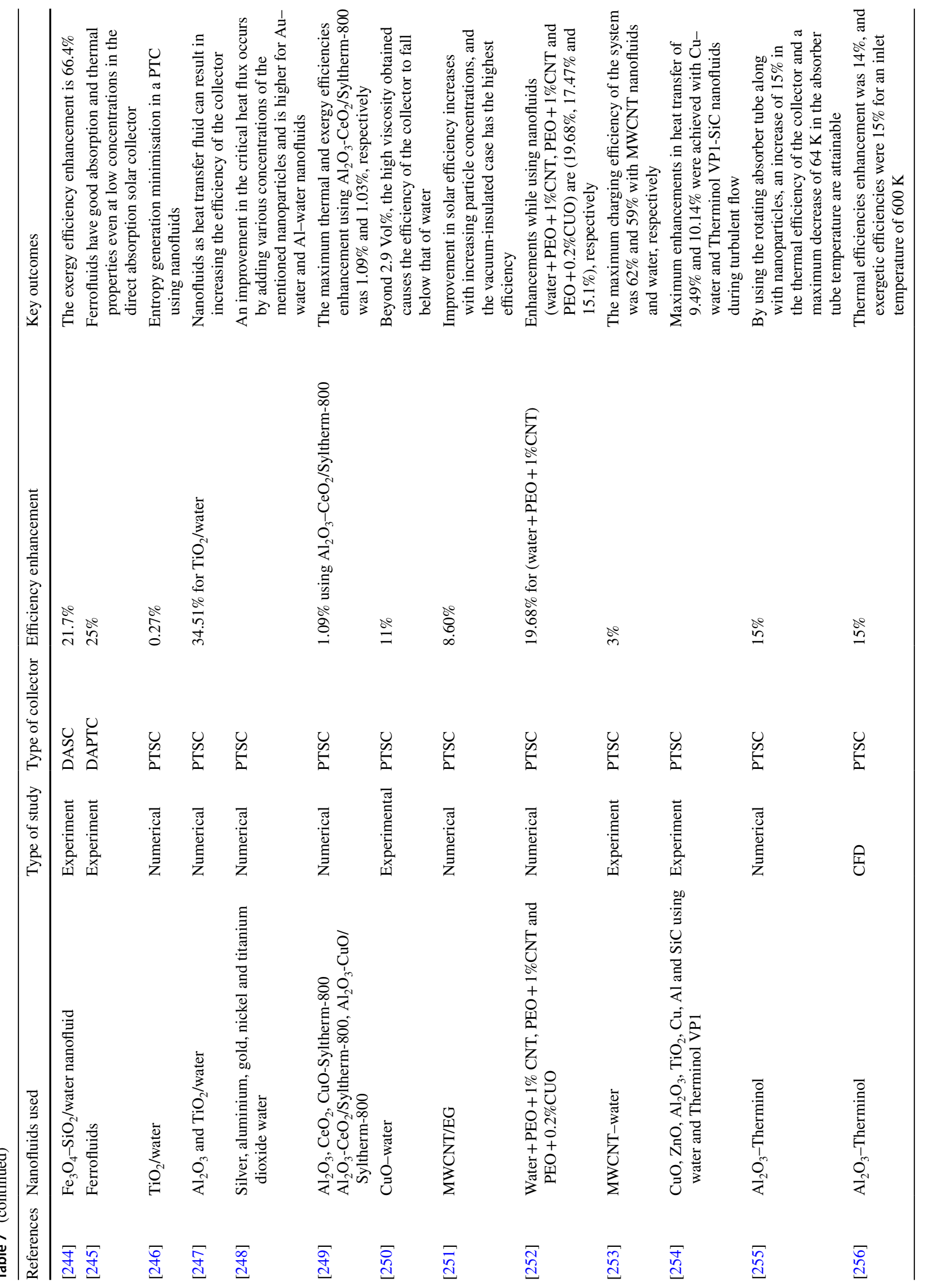




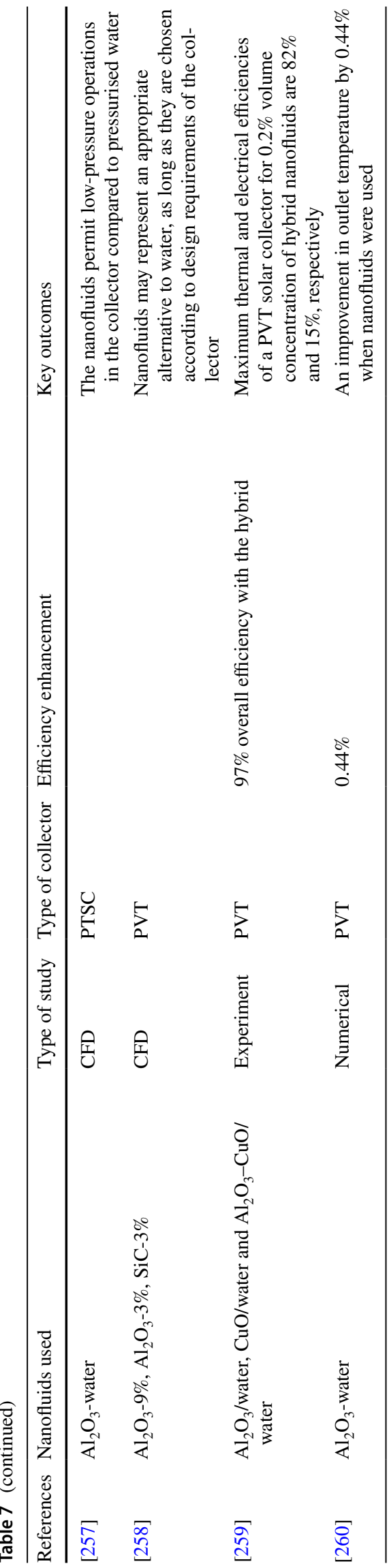

\section{Double-tube heat exchanger}

Double-tube heat exchange is a system is widely used in industries. This type of heat exchanger consists of two concentric tubes, as illustrated in Fig. 13. Researchers have investigated various methods of improving the efficiency of these heat exchangers. Some of these include modifications in dimension, design of much larger systems and the use of a more powerful pump.

A novel method that has been recently promoted is the use of nanofluids [33]. Different nanofluids have been investigated for use in improving the performance of the doubletube heat exchanger. The performance of $\mathrm{TiO}_{2}$-water nanofluid was experimentally investigated in a double-tube HX; the study observed that the heat transfer rate was improved by $14.8 \%$; however, the pressure drop also increases by $51.9 \%$ [261]. The heat transfer coefficient in the double-tube HX was improved by $35 \%$ using MWCNT-water nanofluids [262]. The $\mathrm{Al}_{2} \mathrm{O}_{3}$ /water nanofluid was also used in a double-tube HX, and the result demonstrated a more favourable thermal efficiency of $16 \%$ compared to pure water [263]. A study that investigated the heat transfer and pressure drop in the laminar flow regime using silver-coated silica demonstrated that the heat transfer coefficient could be improved from 7\% to 50\% [264]. The turbulent flow was also investigated for $\mathrm{Al}_{2} \mathrm{O}_{3}$ /water nanofluid, and it was observed that the Nusselt number and Reynolds number increased by $23.2 \%$ and $32.23 \%$, respectively [265].

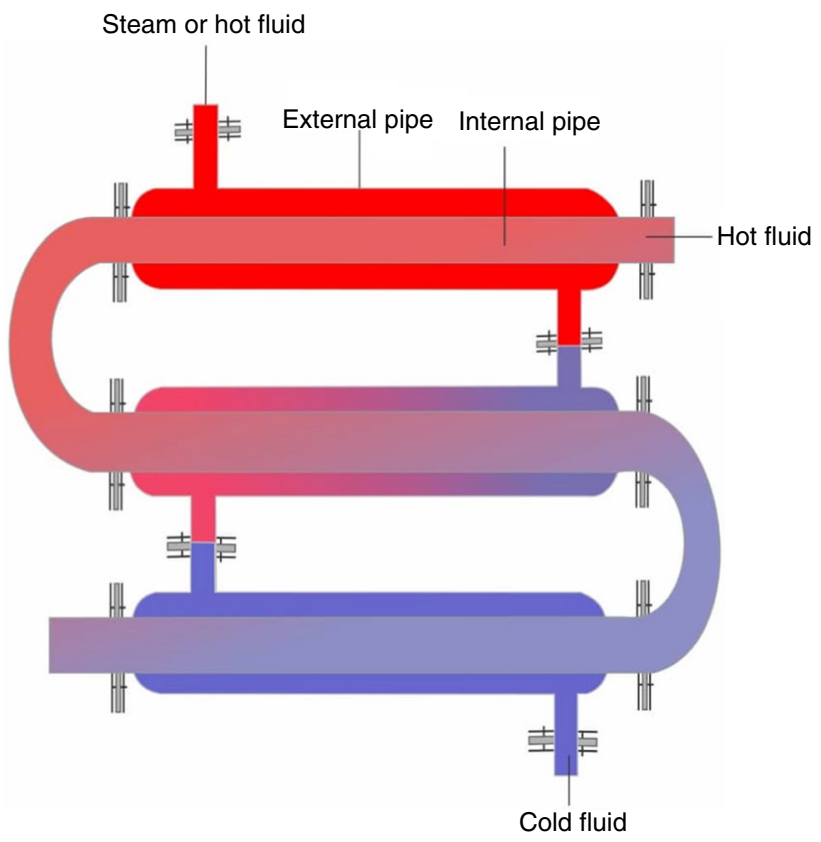

Fig. 13 Double-tube heat exchanger 


\section{Plate heat exchangers}

The plate heat exchanger illustrated in Fig. 14 is a type of compact heat exchanger that is widely used in industries. The application of this type of heat exchanger has been recently spread in many industries. However, there is a need to improve thermal performance and efficiency; the use of nanofluids encourages a higher heat transfer rate within the same dimensions. Multiple studies investigate the use of nanofluids in plate heat exchangers [33]. The effects of using hybrid nanofluids on plate HX performance were numerically investigated [266], where heat transfer augmentation of approximately $16-27 \%$ was apparent for $\mathrm{Al}_{2} \mathrm{O}_{3}-\mathrm{CuO} /$ water nanofluid and $\mathrm{Al}_{2} \mathrm{O}_{3}-\mathrm{TiO}_{2}$ /water nanofluid, respectively. Using an experiment conducted on a plate $\mathrm{HX}$ with $\mathrm{Al}_{2} \mathrm{O}_{3}$ / water nanofluid, new correlations for Nusselt number and heat transfer enhancement rates were derived [267].

A study investigating the heat transfer enhancement when fly ash nanofluids are used as the working fluid concluded that the heat transfer rate was improved by $6-20 \%$ as the concentration increases. The maximum enhancement was achieved using nanoparticle mass concentration of $2 \%$ [268]. The effect of particle size of metal oxide nanofluids on plate $\mathrm{HX}$ was experimentally investigated: $\mathrm{Al}_{2} \mathrm{O}_{3}$-water with particle sizes of 20 and $40 \mathrm{~nm}, \mathrm{TiO}_{2}$ /water with a particle size of 10-25 nm and $\mathrm{SiO}_{2}$-water with a particle size of $20-30 \mathrm{~nm}$. When $\mathrm{SiO}_{2}$-water nanofluid at a mass concentration of $0.2 \%$ was applied, the maximum heat transfer enhancement was achieved, while $\mathrm{Al}_{2} \mathrm{O}_{3}$-water nanofluid achieved the minimum heat transfer enhancement at a mass concentration of $0.1 \%$ [269]. The use of carbon-based nanofluids on brazed plate HX and its characteristic was investigated [270]. The results demonstrate a slight decrease in the pressure, while the heat exchange capacity and system efficiency factor were increased by $9.19 \%$ and $7.28 \%$, respectively, at a mass concentration of $0.6 \%$.

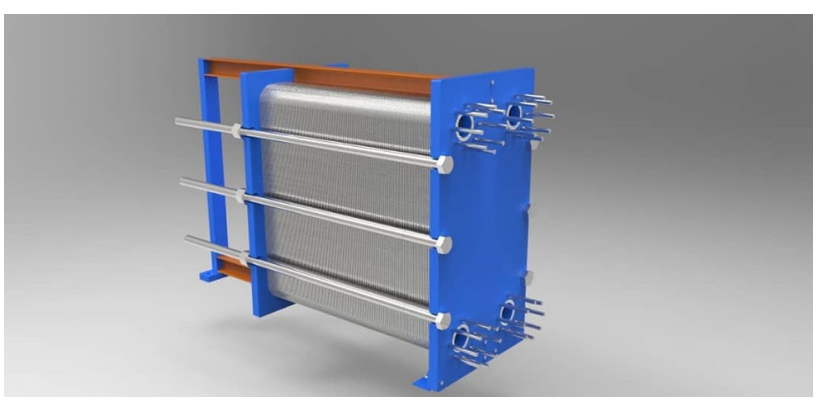

Fig. 14 Image of a plate heat exchanger

\section{Shell and tube heat exchangers}

The shell and tube heat exchanger is a type of heat exchanger that allows for larger surface contact when compared to other types of heat exchangers. It consists of a large outer tube which is the shell and bundles of inner tubes. Figure 15 illustrates a cross-sectional view of this type of heat exchanger. The rate of heat transfer with these heat exchangers is much higher due to their large contact area, although the low thermal conductivity of many of the heat transfer fluids used allows for the use of nanofluids with higher thermal conductivities. The heat transfer performance of carbon-based nanofluids on shell and tube HX was numerically investigated [271]. The study concluded that the nanofluid used improved the thermal performance; however, the pressure drop also increases as the particle volume concentration increased. The effects of using non-Newtonian metallic oxides nanofluids in the shell and tube HX energy-saving and effectiveness were experimentally investigated. Using $\mathrm{Fe}_{2} \mathrm{O}_{3}, \mathrm{Al}_{2} \mathrm{O}_{3}$ and $\mathrm{CuO}$ nanoparticles with water as the base fluid, the highest energy saving was achieved using $\mathrm{CuO}$ [272].

A study investigating the heat transfer characteristics of $\mathrm{TiO}_{2}-\mathrm{EG}$ nanofluids in a shell and tube $\mathrm{HX}$ determined that the heat transfer rate increases as the flow and volume concentration increases [273]. The study obtained the best volume concentration and flow rate for optimum heat transfer, where the best heat transfer rate achieved was $0.277 \mathrm{~J}$ at $0.075 \%$ nanoparticle concentration and a volumetric flow rate of 0.6 1/min. Said et al. [274] conducted an experimental and numerical study on the use of $\mathrm{CuO} /$ water as heat transfer fluid. The outcome demonstrates an increase in the heat transfer coefficient and convective coefficient by $7 \%$ and $11.39 \%$, respectively. Moreover, a $6.81 \%$ reduction in the area could be achieved. The heat transfer improvement on the thermal performance of the shell and tube heat exchanger by the use of $\mathrm{Al}_{2} \mathrm{O}_{3} /$ water and $\mathrm{TiO}_{2} /$ water nanofluids was studied. The maximum heat transfer coefficient enhancement achieved by $\mathrm{Al}_{2} \mathrm{O}_{3} /$ water was $41 \%$, while the maximum heat transfer coefficient using $\mathrm{TiO}_{2} /$ water was $37 \%$ [275].

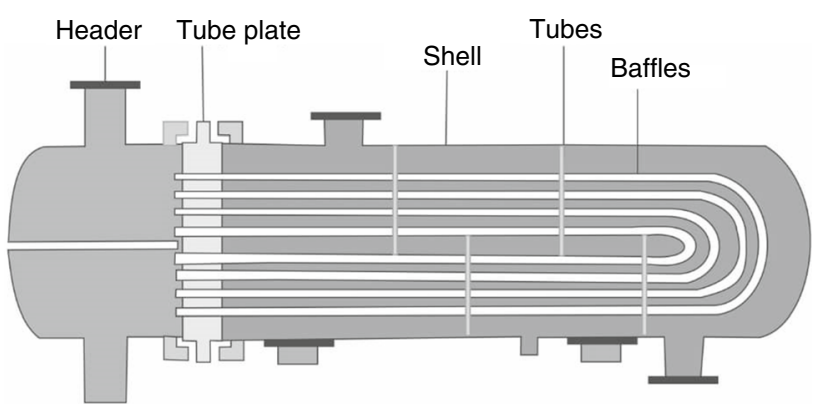

Fig. 15 Cross section of a shell and tube heat exchanger 


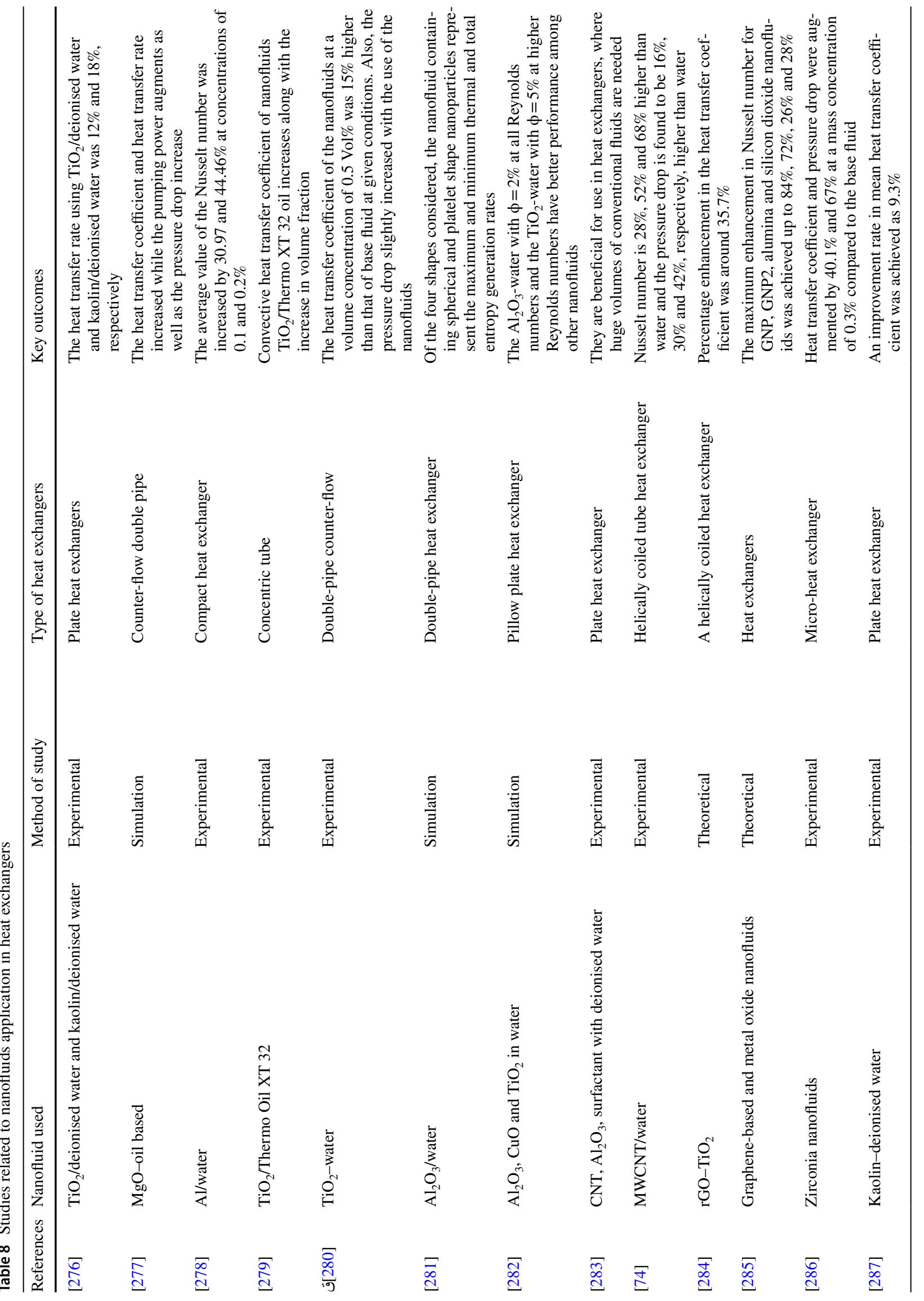




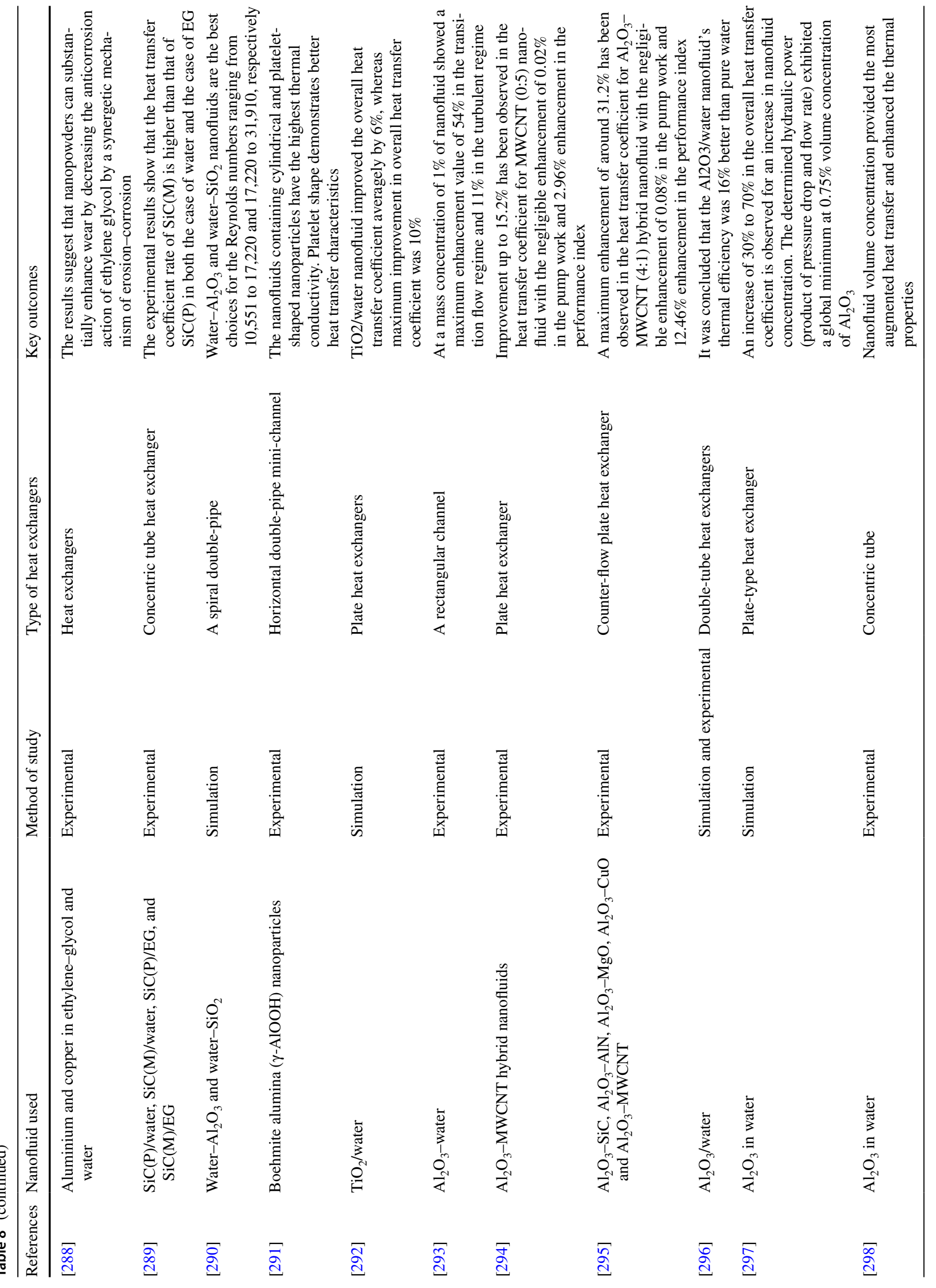




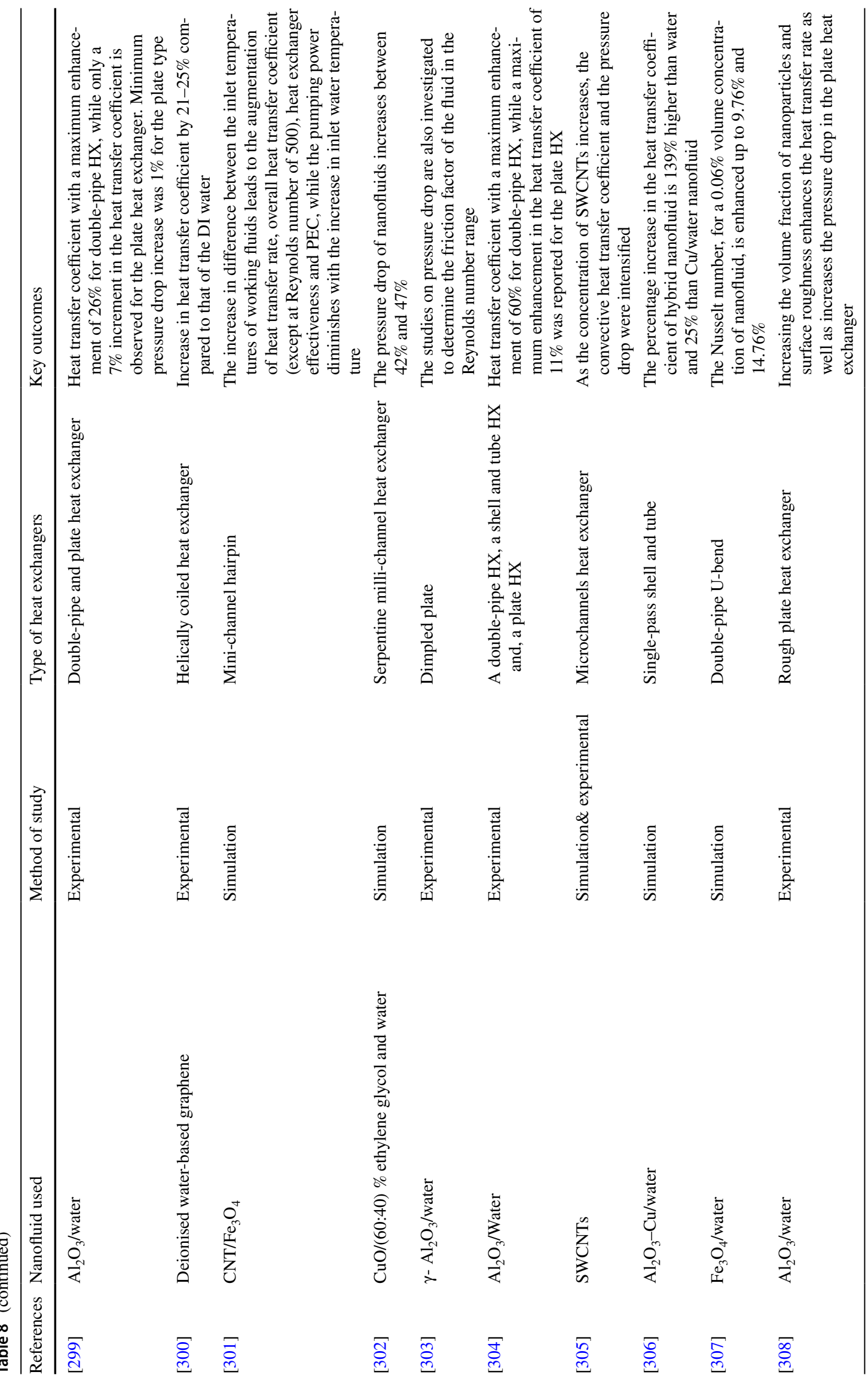


Further studies related to the application of nanofluids in heat exchangers are presented in Table 8.

\section{Nanofluids in electronic cooling}

The advent of the miniaturisation of electronic devices and the need for effective heat management in such devices have pioneered new innovative research areas. The heat generated per unit volume of electronic devices has continued to increase, attributed to the flow of current through a resistance resulting in heat generation. The design of proper thermal management systems in such electronic devices is essential for the efficient and reliable operation of such devices. The use of microchannel heat exchangers in cooling electronic devices is one of the best options available. The channels are small, and as such, they increase the convective heat transfer from the electronic components. These types of heat sinks are used in the thermal management of devices such as supercomputers and batteries and are also used in data centres. The use of nanoparticles to enhance these microchannel heat exchangers has received much attention. The forced and natural convective heat transfer behaviours of nanofluids in various mediums have been studied. Such studies as the heat transfer behaviour of nanofluids in cavities [309-313], porous materials [314-316] and jet impinging [317] all show an increase in the dimensionless heat transfer parameter with the addition of nanoparticles. These studies prove the tremendous potentials of nanofluids in the electronics and data storage industries. Also, the heat transfer behaviour of nanofluids in magnetic fields has shown promising potentials [318].

Vishnuprasad et al. [319] experimentally evaluated the cooling performance of microwave-assisted acid-functionalised graphene (MAAFG) in water. The characterisation of the nanofluid showed that the MAAFG nanofluid had a $55.38 \%$ enhancement in thermal conductivity. The effect of varying the flow rate and nanoparticle volume concentration on the heat transfer coefficient and processor temperature was studied, and the results show that at $0.2 \mathrm{Vol} \%$, there was an increase in the convective heat transfer coefficient by $78.5 \%$. The processor temperature was also decreased by $15 \%$, although a $5 \%$ pressure drop was recorded at $0.2 \mathrm{Vol} \%$ and a flow rate of $10 \mathrm{~mL} \mathrm{~s}^{-1}$. Joy et al. [320] investigated the use of $\mathrm{Cu}$-water and $\mathrm{Al}$-water to increase the critical heat flux (CHF) limit in a heat pipe for electronic cooling. The result of the study demonstrated that nanofluids increased the CHF by $140 \%$ at a mass concentration of $0.01 \%$. Both nanoparticle concentrations represented the optimum value of CHF for both nanofluids without preheating. Zing and Mahjoob [321] theoretically investigated the use of singleand multijet impingements through a porous channel for electronics cooling applications. The study evaluated the effect of two different coolants in their system: water and $\mathrm{TiO}_{2}$-water nanofluids at a volume concentration of $5 \%$. Results demonstrate that the use of $\mathrm{TiO}_{2}$ nanofluid decreased the base temperature of the device more effectively than using water. For enhanced heat transfer in electronic cooling, Bezaatpour and Goharkhah [322] designed a mini heat sink with porous fins operating with a magnetite nanofluid of $\mathrm{Fe}_{3} \mathrm{O}_{4}$-water at volume concentrations up to $3 \%$. The study recorded an increase in heat transfer of $32 \%$ with the use of the ferrofluids at $3 \mathrm{Vol} \%$ and Re of 1040 . The pressure drop also recorded a decrease of $33 \%$ with the use of the ferrofluids.

Al-Rashed et al. [323] evaluated the first and second law performance of a non-Newtonian nanofluid of $\mathrm{CuO}$ and $0.5 \%$ carboxymethyl cellulose (CMC) in water for use in a microchannel heat sink (MCHS). Figure 16 illustrates an offset strip-fin MCHS with a description of its geometric parameters and imposed boundary conditions. By varying the nanoparticle concentration and Reynolds number, the effect of the nanofluids on the surface temperature of the CPU was observed. The results demonstrate that increasing Reynolds number adversely affected the frictional entropy generation and pressure drop. The nanofluid also reduced the surface temperature of the CPU and entropy generation rate in the system. A $2.7 \%$ decrease in the entropy generation rate of the CPU was attained at $1 \mathrm{Vol} \%$ and Re of 300. At 1
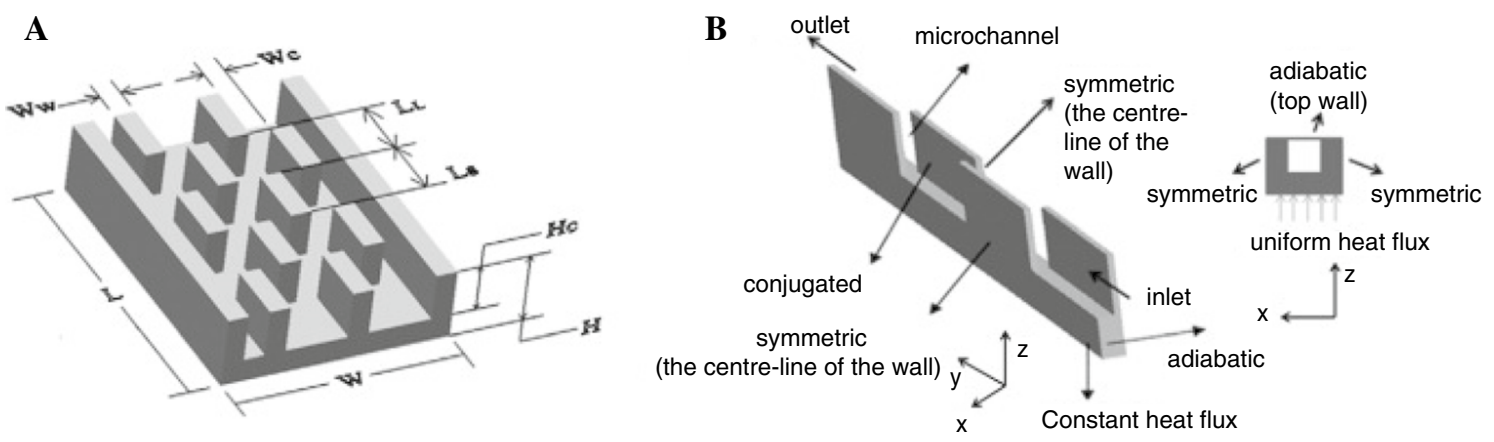

Fig. 16 The schematic of (a) offset strip-fin microchannels, and $\mathbf{b}$ the computational domain of the one unit of microchannels [323], [325] 
Table 9 Studies related to the application of nanofluids in electronic cooling devices

\begin{tabular}{llll}
\hline References & Nanofluid used & Type of study & Cooling device used \\
\hline$[326]$ & $\mathrm{Al}_{2} \mathrm{O}_{3}$-water & Experimental and analytical & Aluminium metallic foam \\
{$[327]$} & $\mathrm{Al}_{2} \mathrm{O}_{3}-\mathrm{H}_{2} \mathrm{O}$ and $\mathrm{CuO}-\mathrm{H}_{2} \mathrm{O}$ & Experimental and analytical & Heat sink \\
& & & \\
{$[328]$} & $\mathrm{Ag}$-water & Numerical & Semicircular lid-driven cavity
\end{tabular}

Key outcomes

Numerical

Pin fin heat sink

Plate-pin heat sink

Heat pipes

Heat sink
Experimental
Higher heat extraction was found at a nanofluid concentration of $0.2 \%$

The minimum base temperatures obtained for $\mathrm{Al}_{2} \mathrm{O}_{3}-\mathrm{H}_{2} \mathrm{O}$ nanofluids and water were $43.4^{\circ} \mathrm{C}$ and $45.2{ }^{\circ} \mathrm{C}$, respectively, for the mini-channel heat sink with $0.5 \mathrm{~mm}$ fin spacing

Investigating the effects of the Richardson numbers of 1 and 10 and nanoparticle volume fractions on the flow field and heat transfer. The best heat transfer is related to $\mathrm{Ri}=1$ and $\varphi=6 \%$ for attack angles of $-45^{\circ}, 0^{\circ},-90^{\circ}, 45^{\circ}$ and $90^{\circ}$

Increase in the particle fraction and velocity reduces the temperature on the heating surface and improves the temperature distribution uniformity

Applying compact heat sink with nanofluids instead of the traditional heat sinks might produce a substantial enhancement in the hydrothermal performance of the heat sinks

The use of nanofluid in the heat pipes resulted in a substantial decrease in the heat source temperature. For the application of nanofluids in heat pipes, the maturity of this technology has reached the Technology Readiness Level of 8 for surveillance systems tested

It is found that nanofluids could enhance the microchannel heat sink performance as compared with that using pure water as the coolant due to the increase in thermal conductivity of coolant with the addition of nanoparticles

For the $1 \mathrm{vol} \% \mathrm{Al}_{2} \mathrm{O}_{3}$-water nanofluid, when the Reynolds number increases from 500 to 1000 , the pressure drop and frictional entropy generation of rectangular microchannel heat sink increase by $144 \%$ and $389 \%$, respectively

Thermal entropy generation decreases at higher $\mathrm{TiO} 2$ nanofluid concentration and flow rate. The frictional entropy generation increases for higher flow rate and nanofluid particle concentration 
Table 9 (continued)

\begin{tabular}{|c|c|c|c|c|}
\hline References & Nanofluid used & Type of study & Cooling device used & Key outcomes \\
\hline$[334]$ & $\begin{array}{l}\text { Graphene nanoplatelets-Ag/ } \\
\text { water }\end{array}$ & Numerical & Heat sink & $\begin{array}{l}\text { Results showed that at an opti- } \\
\text { mum percentage of dispersed } \\
\text { nanosheets in water, the heat } \\
\text { transfer behaviour of the cool- } \\
\text { ant is enhanced }\end{array}$ \\
\hline$[335]$ & Aluminium/water & Numerical & Heat sink & $\begin{array}{l}\text { With the nanofluids, the heat } \\
\text { transfer decreases by } 22 \% \text { and } \\
\text { total irreversibility decreases } \\
\text { by } 21 \%\end{array}$ \\
\hline [336] & $\mathrm{Al}_{2} \mathrm{O}_{3}-\mathrm{NH}_{3}$ & Numerical & Heat sink & $\begin{array}{l}\text { The ammonia base nano- } \\
\text { fluid }\left(\mathrm{Al}_{2} \mathrm{O}_{3}-\mathrm{NH}_{3}\right) \text { out- } \\
\text { performed other coolants } \\
\left(\mathrm{SiC}-\mathrm{H}_{2} \mathrm{O}, \mathrm{TiO}_{2}-\mathrm{H}_{2} \mathrm{O}, \mathrm{H}_{2} \mathrm{O}\right. \\
\left.\text { and } \mathrm{Al}_{2} \mathrm{O}_{3}-\mathrm{H}_{2} \mathrm{O}\right) \text { in pumping } \\
\text { power demand with } 0.144, \\
0.702,0.724,0.94 \text { and } 1.015 \text { for } \\
\mathrm{Al}_{2} \mathrm{O}_{3}-\mathrm{NH}_{3}, \mathrm{SiC}_{-} \mathrm{H}_{2} \mathrm{O}, \mathrm{TiO}_{2}- \\
\mathrm{H}_{2} \mathrm{O}, \mathrm{H}_{2} \mathrm{O} \text { and } \mathrm{Al}_{2} \mathrm{O}_{3}-\mathrm{H}_{2} \mathrm{O}, \\
\text { respectively }\end{array}$ \\
\hline [337] & $\mathrm{Cu}$-water, $\mathrm{Al}$-water & Numerical & Hemispherical cavity & $\begin{array}{l}\text { The numerical approach shows } \\
\text { that the average surface } \\
\text { temperature of the electronic } \\
\text { component decreases as the } \\
\text { volume fraction increases, } \\
\text { confirming the efficiency of the } \\
\text { nanofluid in natural convective } \\
\text { heat transfer improvement }\end{array}$ \\
\hline [321] & $\begin{array}{l}\mathrm{TiO}_{2} \text {-water, } \mathrm{Al}_{2} \mathrm{O}_{3} \text {-water, } \\
\text { MWCNT-water, diamond in } \\
\text { 40:60 EG/water }\end{array}$ & Numerical & Porous filled heat exchanger & $\begin{array}{l}\text { The use of titanium dioxide } \\
\text { nanofluids }\left(\mathrm{TiO}_{2}\right) \text { as a cool- } \\
\text { ant for both copper and APG } \\
\text { porous matrices at low and high } \\
\text { porosity structures, and both } \\
\text { square and rectangular inlet } \\
\text { cross sections improve the cool- } \\
\text { ing efficiency and temperature } \\
\text { uniformity over the base }\end{array}$ \\
\hline [338] & $\mathrm{Cu}$-water & Experimental & Hemispherical cavity & $\begin{array}{l}\text { The } \mathrm{Cu}-\mathrm{H}_{2} \mathrm{O} \text { nanofluids degrade } \\
\text { with its age and the number of } \\
\text { times it has been used }\end{array}$ \\
\hline [339] & Ag-water & Numerical & Microchannel heat sink & $\begin{array}{l}\text { The addition of nanoparticles } \\
\text { intensified the convective heat } \\
\text { transfer coefficient leading to a } \\
\text { decrease in the CPU tempera- } \\
\text { ture and thermal irreversibility } \\
\text { rate and enhanced the CPU } \\
\text { temperature uniformity }\end{array}$ \\
\hline$[340]$ & $\mathrm{SiC} / \mathrm{EG}$-water & Numerical & Wavy sinusoidal mini tube & $\begin{array}{l}\text { Based on the performance evalu- } \\
\text { ation criterion, the optimum } \\
\text { tube using EG/water-based } \\
\text { SiC nanofluid is } 1.67 \text { for a } 4 \% \\
\text { volume fraction and nano- } \\
\text { particle diameter of } 90 \mathrm{~nm} \text { at } \\
\mathrm{Re}=15,000\end{array}$ \\
\hline
\end{tabular}

Vol\% and $\mathrm{Re}$ of 700 , the $\mathrm{CMC} / \mathrm{CuO}$ water had an optimal ratio of heat transfer to the pressure drop of 2.29. Qui et al. [324] investigated the interfacial transport between vertically aligned carbon nanotube and electronic heat sinks.
Their results show that $\mathrm{CNT}$ reduced the thermal contact resistances from $10 \mathrm{~mm}^{2} \mathrm{~K} / \mathrm{W}$ to $0.3 \mathrm{~mm}^{2} \mathrm{~K} / \mathrm{W}$. Other studies related to the use of nanofluid in improving heat transfer in electronic devices are detailed in Table 9. 


\section{Nanofluids in automobile radiators}

The thermal management of automobile engines is necessary for the effective and efficient operation of the automobile. Figure 17 illustrates a schematic diagram of a car radiator which functions as a heat exchanger that disperses the heat generated from the operation of the engines. Recently, the use of nanofluids as alternative coolants in radiators have been investigated. Elsaid [341] experimentally investigated the performance of an engine radiator using nanofluids in the hot arid climate of Cairo, Egypt. Two nanoparticles $\mathrm{Al}_{2} \mathrm{O}_{3}$ and $\mathrm{Co}_{3} \mathrm{O}_{4}$ are used in varying concentrations in a base fluid of EG/water at 0:100\%, 10:90\% and 20:80\%. A schematic of his experimental set-up for investigating nanofluids effectiveness in radiators is illustrated in Fig. 18. The study confirms that the use of $\mathrm{Co}_{3} \mathrm{O}_{4} / \mathrm{EG}$-water results in a more favourable thermal performance than that of $\mathrm{Al}_{2} \mathrm{O}_{3} / \mathrm{EG}$-water. The cobalt oxide also contributed to larger energy savings when compared to alumina. The nanoparticles enhanced the Nusselt number by $31.8 \%$; however, this was at the expense of an increase of $16 \%$ in friction factor. This reduction in friction factor resulted in the need for additional pump power for the nanofluids. It is essential to note that pump power was also intensified with the use of EG-water as the base fluid. The
Fig. 17 Schematic diagram of a car radiator

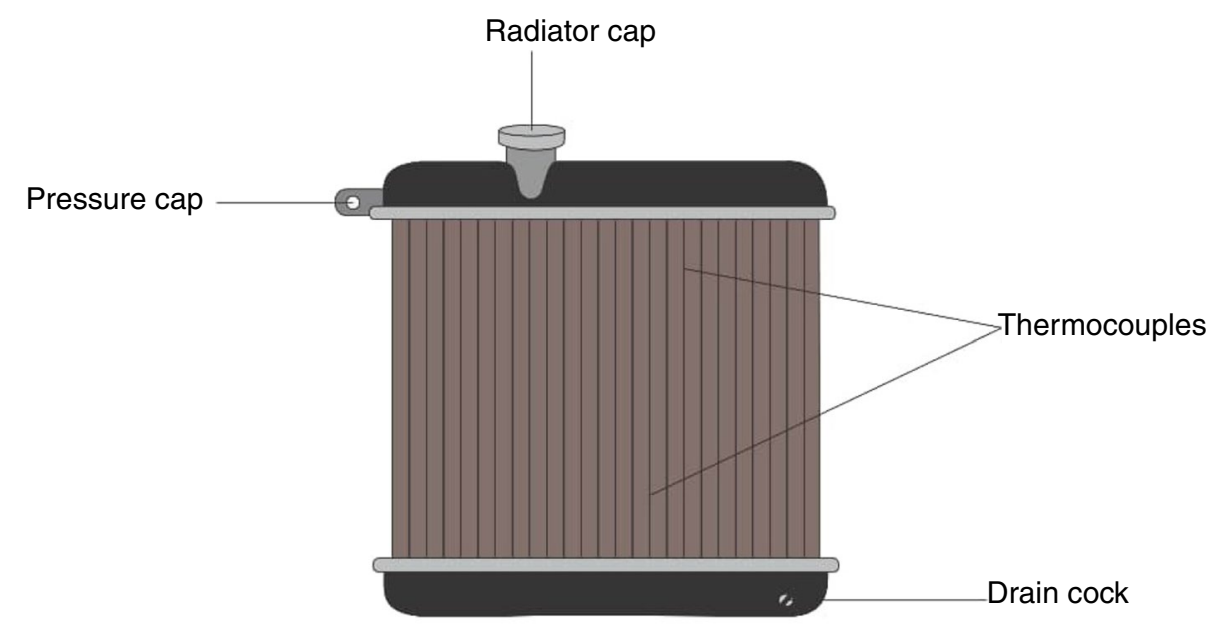

Fig. 18 Schematic diagram of the experimentation system used by Elsaid [341]

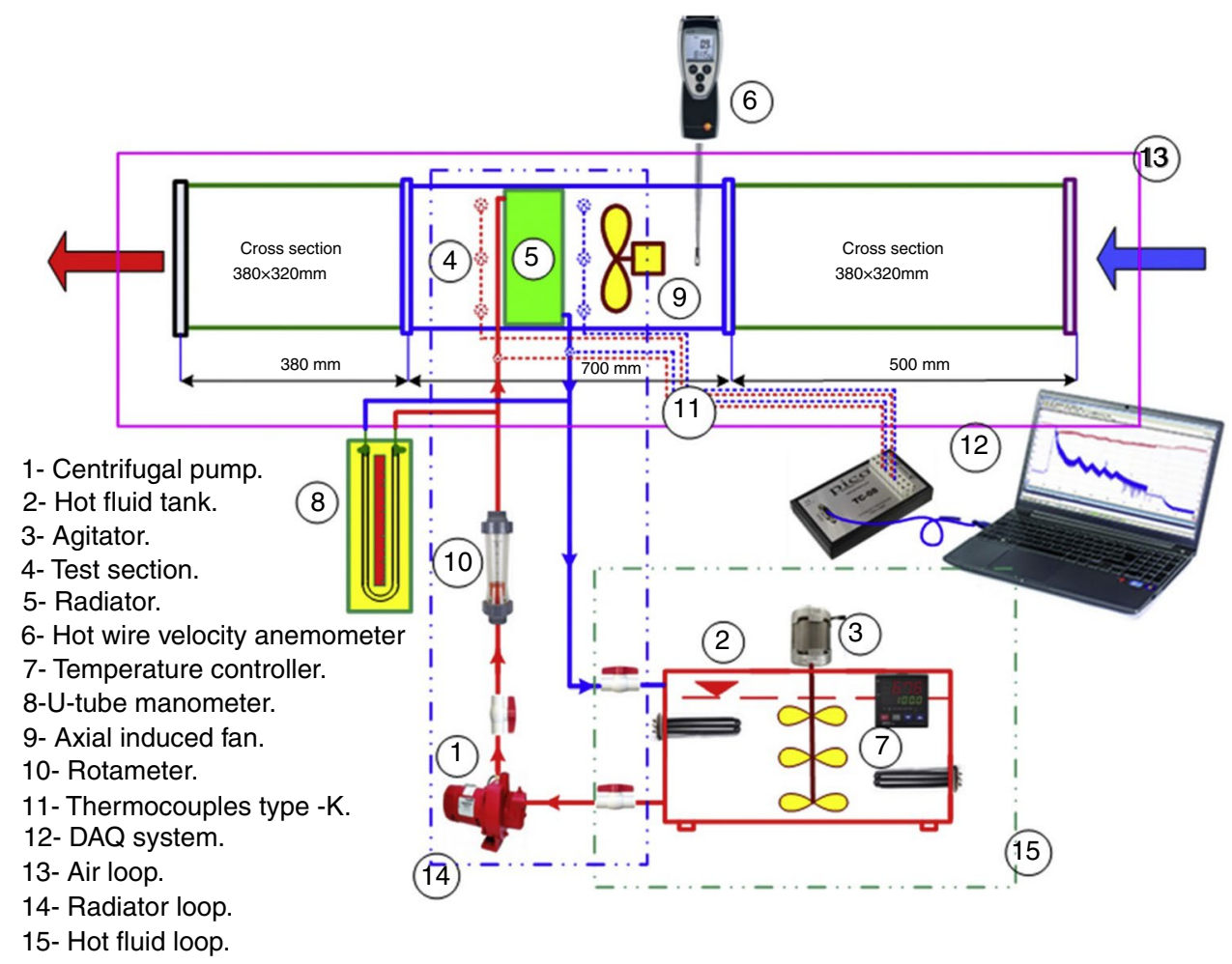


performance of a hybrid of $\mathrm{Al}_{2} \mathrm{O}_{3}$ nanocellulose dispersed in EG/water in a radiator was investigated by Naiman et al. [342], who recorded a maximum thermal conductivity at $0.9 \mathrm{Vol} \%$ and concluded that the nanofluids were more efficient than the use of EG-water. Al Rafi et al. [343] studied the heat transfer potential of $\mathrm{Al}_{2} \mathrm{O}_{3} / \mathrm{EG}$-water and $\mathrm{CuO} /$ $\mathrm{EG}-$ water in a car radiator, revealing that the addition of EG into the water decreased the overall heat conductance by $20-25 \%$. Moreover, experimental results demonstrate that $\mathrm{Al}_{2} \mathrm{O}_{3} / \mathrm{EG}$-water at $0.1 \mathrm{Vol} \%$ and $\mathrm{CuO} / \mathrm{EG}$-water at 0.2 $\mathrm{Vol} \%$ improved the heat transfer potential of the radiator by $30-35 \%$ and $40-45 \%$, respectively.

Kumar and Sahoo [344] analysed the energy and exergy performance of a wavy fin radiator using $\mathrm{Al}_{2} \mathrm{O}_{3}$-water nanofluid as a coolant. The effect of various nanoparticle shapes (spherical, brick and platelet) on the radiator's effectiveness, pump power and heat transfer was also investigated; results show that the shape of the nanoparticles affected their performance in the radiator. Furthermore, it was observed that the spherical nanofluids had a $21.98 \%$ enhancement in heat transfer when compared to the platelet nanofluid. A $13 \%$ enhancement in the exergy efficiency of the spherical nanofluids determined that the use of spherical nanofluids performed better in comparison with nanofluids of other shapes. Contreras et al. [345] experimentally investigated the thermo-hydraulic performance of silver/EG-water and graphene/EG-water for use in a radiator. The study showed that silver/EG-water had an improved heat transfer rate of $4.7 \%$ when compared to EG-water, while the heat transfer using graphene nanofluid decreased by $11 \%$ and $3 \%$ at concentrations for $0.01 \mathrm{Vol} \%$ and $0.05 \mathrm{Vol} \%$, respectively, when compared to water. The thermo-hydraulic performance coefficient of all nanofluids showed that nanographene at 0.1 Vol\% and silver nanofluids at $0.05 \mathrm{Vol} \%$ had values of $1.5 \%$ and $2.5 \%$, respectively, while graphene nanofluids at concentrations of $0.01 \mathrm{Vol} \%$ and $0.05 \mathrm{Vol} \%$ were not suitable for use in the radiator as they performed below EG-water. Other studies on the use of nanofluid in improving the performance of automobile radiators are detailed in Table 10.

\section{Nanofluids in thermal storage}

Thermal energy storage (TES) is a very important part of the utilisation, conservation and development of new and existing energy sources. The three forms of TES are chemical energy storage, sensible heat storage and latent heat storage. The difference between sensible and latent heat storage types is related to the phase transition of the thermal material used for storage. There is a phase transition before energy is released or stored in the Latent TES, while sensible TES does not require a phase change and operates mainly with the changing temperature of the material. Phase change materials (PCMs) can be used in both cases and is essential to the operation of the latent TES unit. The drawbacks of PCMs are their low thermal properties.

A classification of the various materials used in thermal energy storage is presented in Fig. 19. Highlighting the studies that investigate the effects of nanoparticles on the thermal performance of PCM, Bondareva et al. [357] investigated the heat transfer performance of the nano-enhanced phase change material system under the inclination influence. Studying the performance of paraffin enhanced with $\mathrm{Al}_{2} \mathrm{O}_{3}$ nanoparticles, they discovered that; for small inclinations of the cavity, when convective heat transfer dominates, an increase in the nanoparticles volume fraction leads to an increase in the melting time. Navarrete et al. [358] proposed the use of molten salt-based nanofluid for both sensible and latent energy storage. The molten salt nitrate would serve as the base fluid for the nano-encapsulated phase change materials (nePCM) consisting of Al-Cu alloy nuclei. Oxidation that occurs as a result of the metals been exposed to air would serve as an encapsulation over the nanoparticles. The study tested the resistance of the oxide shell to temperatures up to $570{ }^{\circ} \mathrm{C}$, demonstrating that although the specific heat and by extension the sensible heat storage decreased with the presence of solid content, the phase change enthalpy and latent storage capacity increased by $17.8 \%$ at constant volume bases. Furthermore, the thermal conductivity of the salt nitrates increased with the addition of nanoparticles enhancing the heat transfer performance of the PCM nanofluid. Martin et al. [359] developed a novel nePCM from two fatty acids of capric acid (CA) and capric-myristic (CAMA) using $\mathrm{nSiO}_{2}$ for thermal energy management in a building. The addition of the $1.5 \% \mathrm{nSiO}_{2}$ significantly improved both the thermal conductivity and specific heat of nePCM. The thermal stability test after 2000 thermal cycles indicated that the addition of nanoparticles did not affect the thermal stability of CA, but slightly improved that of CA-MA. The sensible heat storage capacity of both fatty acids improved due to a $20 \%$ improvement in specific heat capacity at a volume concentration of $1 \%$; however, the latent energy storage capacity of both fatty acids was lowered. The use of the $\mathrm{nSiO}_{2}$ nanoparticles strengthens on the initial weaknesses of the fatty acids as heat storage fluids as Fig. 20 illustrates.

Ding et al. [360] studied the use of two crystal forms of $\mathrm{TiO}_{2}$ nanoparticles (anatase referred to as $\mathrm{A}$ and rutile referred to as $\mathrm{R}$ ) dispersed in water operating in a microchannel inside a PCM used to enhance the thermal storage in miniatured devices. The two nanofluids $\mathrm{R}_{-1} \mathrm{TiO}_{2}-$ water and $\mathrm{A}-\mathrm{TiO}_{2}$-water were thermally tested, and both nanofluids confirmed to be stable. $\mathrm{R}^{-\mathrm{TiO}_{2}}$-water was more stable than $\mathrm{A}-\mathrm{TiO}_{2}$, and the thermal conductivity of $\mathrm{R}-\mathrm{TiO}_{2}$ was found to be higher than that of $\mathrm{A}-\mathrm{TiO}_{2}$. The addition of $\mathrm{TiO}_{2}$-water in the microchannel at a volume concentration of $0.5 \%, 0.7 \%$ and $1.0 \%$ decreased the complete melting time of paraffin by $7.78 \%, 16.51 \%$ and $32.90 \%$ while increasing the complete 


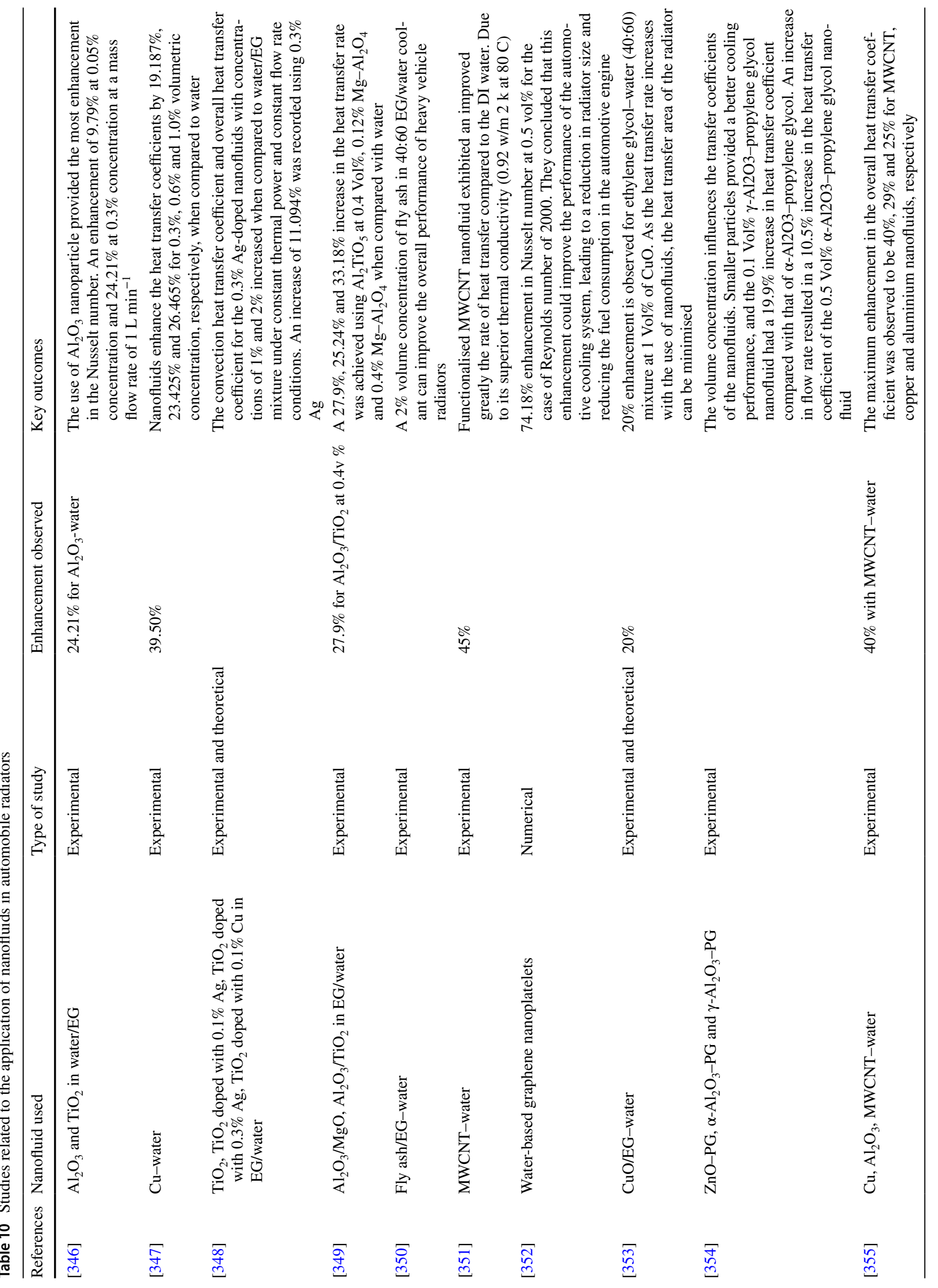


solidification time by $7.42 \%, 15.65 \%$ and $22.57 \%$ in the solidification process. The use of nanofluids increased the melting and solidification pressure by less than $8 \%$ in both cases. Harikrishnan et al. [361] investigated the effect of $\mathrm{Ni}-\mathrm{ZnO}$ nanocomposite dispersed in oleic acid on the thermal conductivity and phase change properties of the resulting nePCM. The thermal reliability along with the freezing and melting characteristics of the nePCM was studied, and the thermal conductivity of the nanofluids was confirmed to be higher than that of oleic acid. For the mass fraction considered, $0.3,0.6,0.9$ and $1.2 \%$ of $\mathrm{Ni}-\mathrm{ZnO}$, the complete melting and solidification processes were enhanced by $7.03 \%, 14.06 \% 24.21 \%, 29.69 \%$ and $7.58 \%, 13 \%, 19.13 \%$, $28.52 \%$, respectively. The trend confirms that the time required in melting and freezing was lowered with the use of the nano-PCMs. Other studies related to the use of nanoparticles in thermal storage units are detailed in Table 11.

\section{Nanofluids in refrigeration}

Nanofluids can also be used in air conditioning and refrigeration systems. The negative environmental effect of using chlorofluorocarbons along with hydrofluorocarbons has propelled research into alternative refrigerants. Traditionally, vapour compression refrigeration systems (VCRSs) are used in the cooling industry; however, the major drawback to this system is the large compressor power requirement. An alternative heat-powered absorption refrigeration system (VARS) has been developed, although the coefficient of performance (COP) of these systems is still below those of the VCRS. Nanoparticles have been used to create new refrigerants known as nanorefrigerants which can improve the COP of both the VARS and VCRS and decrease the compression work of the VCRS.

Rahman et al. [376] analysed the effect of using nanoparticles in a refrigerant. The effect of the nanorefrigerant on the compression work and COP of the air conditioning system is observed. They observed that the addition of 5\% SWCNT to R407c refrigerant at temperatures between $283 \mathrm{~K}$ and $308 \mathrm{~K}$ resulted in a reduction in the energy consumption of the compressor by $4 \%$. Moreover, the nanorefrigerant had improved the thermal conductivity and specific heat values by $17.02 \%$ and $10.06 \%$, respectively. The nanorefrigerant also enhanced the COP by $4.59 \%$ and reduced the compressor work by $34 \%$ when compared to conventional vapour compression refrigeration systems.

Jiang et al. [377] investigated the effect of $0.5 \% \mathrm{TiO}_{2}$ and $0.02 \%$ SDBS on the COP of ammonia absorption refrigeration system (AARS). The experimental set-up of the test rig used in their investigations is illustrated in Fig. 21. Outcomes of the experiment were compared to that of $0.1 \%, 0.3 \%$ and $0.5 \%$ of $\mathrm{TiO}_{2}$ dispersed in ammonia water as a refrigerant. The results demonstrate that the 
Fig. 19 Classification of the various thermal energy storage materials (modified from [362])
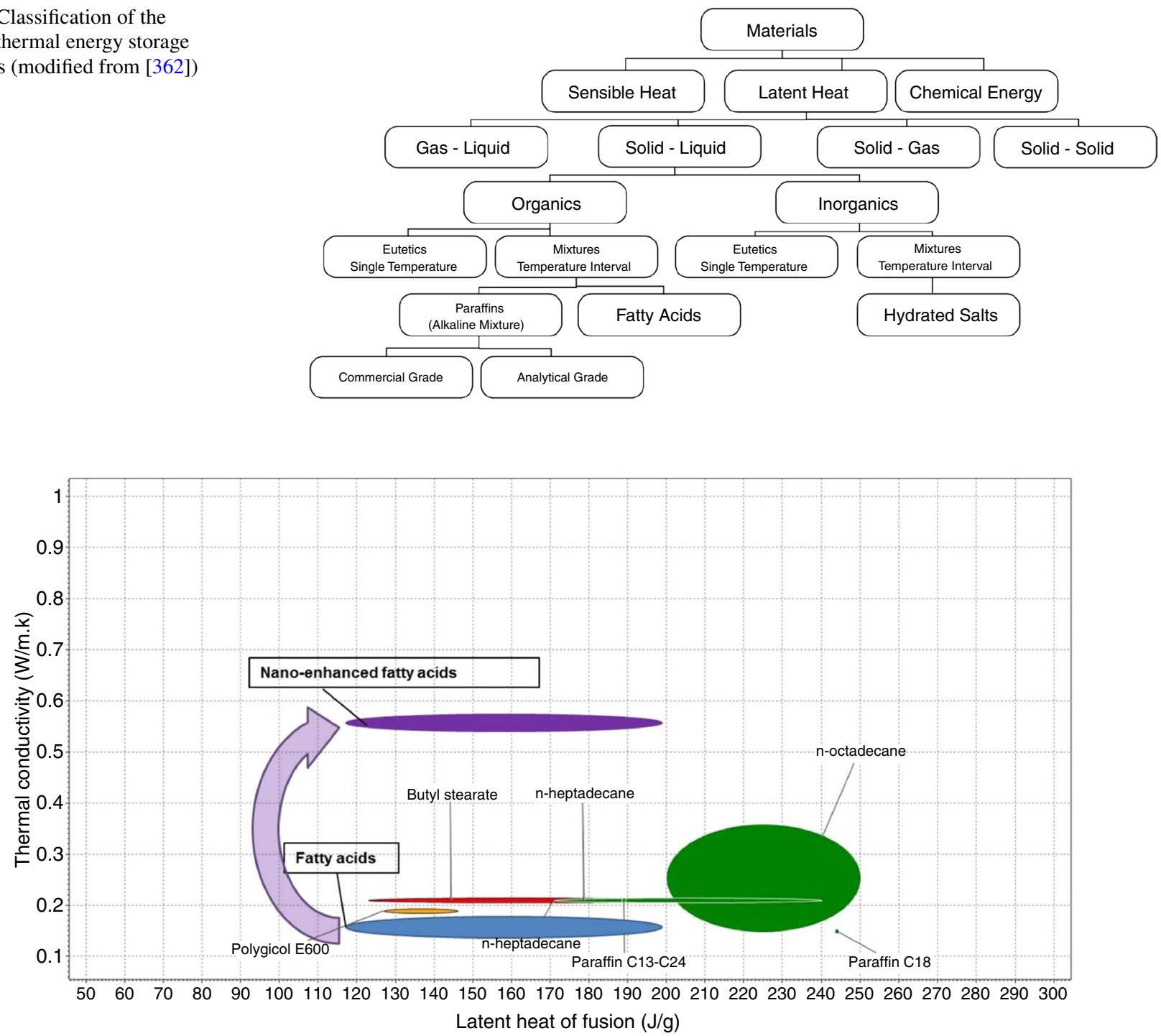

Fig. 20 Organic PCMs that plot latent heat of fusion vs thermal conductivity [359]

addition of $\mathrm{TiO}_{2}$ to any of the concentrations studied significantly improved the COP of the AARS. It was observed that the further addition of $0.02 \%$ of SDBS improved the stability of the mixture and enhanced the COP by $27 \%$ as shown in Fig. 22. In conclusion, the improvement in COP of the AARS was strongly dependent not only on nanoparticle concentration but also on the number of nanoparticles stably dispersed in the base fluid. Jeyakumar et al. [378] investigated the use of three nanoparticles $\mathrm{CuO}, \mathrm{ZnO}$ and $\mathrm{Al}_{2} \mathrm{O}_{3}$ in the refrigerant of a vapour compression system. The nanoparticles were added to refrigerant R134 at concentrations of $0.06 \%, 0.08 \%$ and $0.1 \%$ with $0.1 \%$ polyester oil as a lubricant. The results demonstrate an improvement in COP of $12.2 \%$ and $3.42 \%$ using the nanorefrigerant of $\mathrm{CuO}$ and $\mathrm{Al}_{2} \mathrm{O}_{3}$, respectively. Also, a reduction in the power consumption of $1.39 \%$ and $0.6 \%$ with $\mathrm{CuO}$ and
$\mathrm{Al}_{2} \mathrm{O}_{3}$, respectively, was observed. Other studies related to the use of nanoparticles in compression and absorption refrigeration systems are given in Table 12 .

The use of nanofluids in many other devices has also been studied, and some of these include the application of nanofluids in solar still $[389,390]$ and also in mineral oil to enhance the insulating properties of high-voltage AC and DC transformers as proposed by Rafiq et al. [391].

\section{Challenges and future prospects}

Due to stability concerns with nanofluids, exponential improvements are required for nanofluids to reach their full potential as heat transfer fluids. The problems with stability are more obvious in liquids with low viscosity than 
Table 11 Studies related to the application of nanofluids in thermal energy storage

\begin{tabular}{llll}
\hline References & Nanofluid used & Type of study & Enhancement observed \\
\hline$[363]$ & R1234Ze/UiO-66 & Molecular simulations & Thermal heat storage \\
& & & \\
{$[364]$} & UIO-66/ $\mathrm{H}_{2} \mathrm{O}$ nanofluids & Experiment and theoretical & Thermal heat storage
\end{tabular}

[364] UIO-66/ $\mathrm{H}_{2} \mathrm{O}$ nanofluids $\quad$ Experiment and theoretical Thermal heat storage

$$
\mathrm{Al}_{2} \mathrm{O}_{3} \text {-water }
$$

Experimental

$$
\mathrm{SiO}_{2}-\mathrm{NaNO}_{3} \text { and } \mathrm{KNO}_{3}
$$

Experimental and molecular dynamics simulation
Thermal heat storage
Thermal heat storage

Thermal heat storage
Key outcomes

Adding UIO-66 particles in organic R1234ze can enhance the thermal energy storage density of R1234ze, and the thermal energy storage density increases as the UIO-66 mass fraction rises

The results of both methods suggest that the thermal energy storage capacity of UIO-66/ $\mathrm{H}_{2} \mathrm{O}$ nanofluids is enhanced with the increase in the mass fraction of UIO-66

The percentage of reduction in charging time of about $22 \%$ was achieved for high nanoparticle concentration. Also, an enhancement in charging time by increasing the refrigerant flow rate reached $38 \%$ when the mass flux varied from 200 to $400 \mathrm{~kg} / \mathrm{m}^{2} \mathrm{~s}$

Average enhancements of specific heat capacity using 10 , 20 and $30 \mathrm{~nm}$ nanoparticles in the liquid phase were found to be $8.4 \%, 26.7 \%$ and $19.4 \%$, respectively

The heat transfer rate is higher at lower fins due to the strong aiding effects of buoyancy force resulting from the use of nanoparticles

The nano-PCM enhances the solar thermal conversion capacity by enhancing the light absorption ability of PCMs

The melting and solidification show that the latent thermal storage is enhanced with nanoparticles when compared to the base material

Nanoparticle doping complex effects on the corrosion rates of carbon steel. In particular, if the negative effect of microbubbles of air trapped between the nanoparticles is not predominant, one can obtain reduced corrosion rates due to the incorporation of the nanoparticles into the oxidation layer

Latent thermal energy storage An increase in the nanoparticles volume fraction improves the melting rate 
Table 11 (continued)

\begin{tabular}{|c|c|c|c|c|}
\hline References & Nanofluid used & Type of study & Enhancement observed & Key outcomes \\
\hline$[372]$ & $\mathrm{SiO}_{2}-\mathrm{KCl}$ & Molecular dynamics simulation & Thermal energy storage & $\begin{array}{l}\text { It is found that the specific } \\
\text { heat capacity is significantly } \\
\text { enhanced in the systems where } \\
\text { the cross-correlation covari- } \\
\text { ance is smaller than }-0.041 \text {. } \\
\text { While when the cross-cor- } \\
\text { relation covariance is } 0 \text {, the } \\
\text { specific heat capacity is not } \\
\text { enhanced }\end{array}$ \\
\hline$[373]$ & MWCNT and PAA/water & Experiment & Thermal energy storage & $\begin{array}{l}\text { The maximum supercooling } \\
\text { degree declines up to } 95 \% \\
\text { by adding MWCNT with the } \\
\text { variation of particle size and } \\
\text { concentration }\end{array}$ \\
\hline$[374]$ & $\begin{array}{l}\mathrm{CeO}_{2}-\mathrm{WC} / \text { water and } \mathrm{SiC}-\mathrm{WC} / \\
\text { water }\end{array}$ & Experiment & Thermal energy storage & $\begin{array}{l}\text { The melting and solidification } \\
\text { time for release and storage of } \\
\text { thermal energy decreases with } \\
\text { an increase in the concentra- } \\
\text { tions of }\left(\mathrm{CeO}_{2}-\mathrm{WC}\right) \text { and } \\
\text { ( } \mathrm{SiC}-\mathrm{WC}) \text { nanoparticles }\end{array}$ \\
\hline$[375]$ & $\mathrm{CuO}-$ water & Numerical & Thermal energy storage & $\begin{array}{l}\text { The use of nanoparticles can } \\
\text { accelerate the discharging rate }\end{array}$ \\
\hline
\end{tabular}

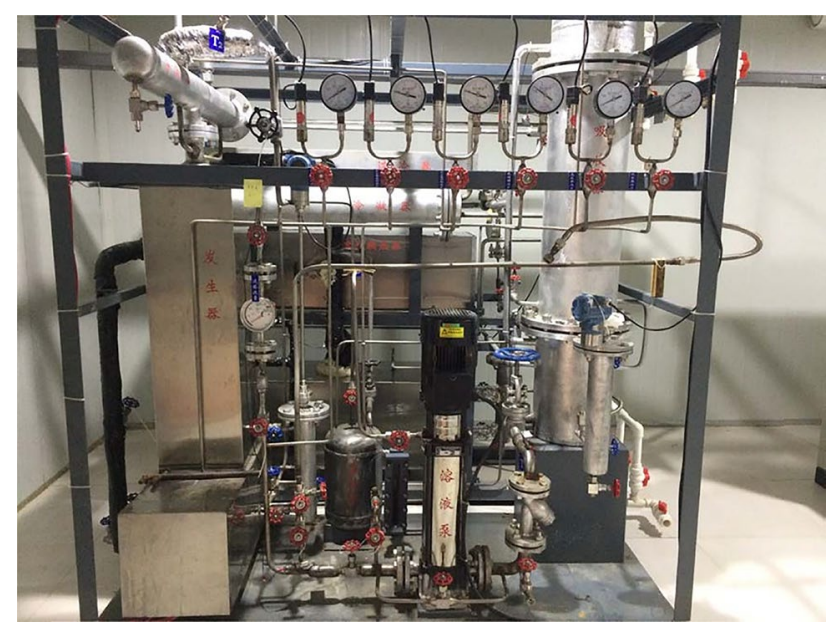

Fig. 21 Test rig for investigating the influence of $\mathrm{TiO}_{2}$ nanoparticles on AARS [377]

liquids with high viscosity. Most of the current methods used to increase fluid stability appear to fall short in certain regards. $\mathrm{pH}$ modulation has demonstrated promising signs of improving the stability of nanofluids; however, acidic and basic solutions exponentially increase corrosion in metals and would thus render heat transfer system untenable. The addition of surfactants has the potential to improve nanofluids stability, however, at high-temperature surfactants tend to foam and decrease the overall efficiency of the system. The most promising technique for increasing fluid stability is by improving the synthesis techniques

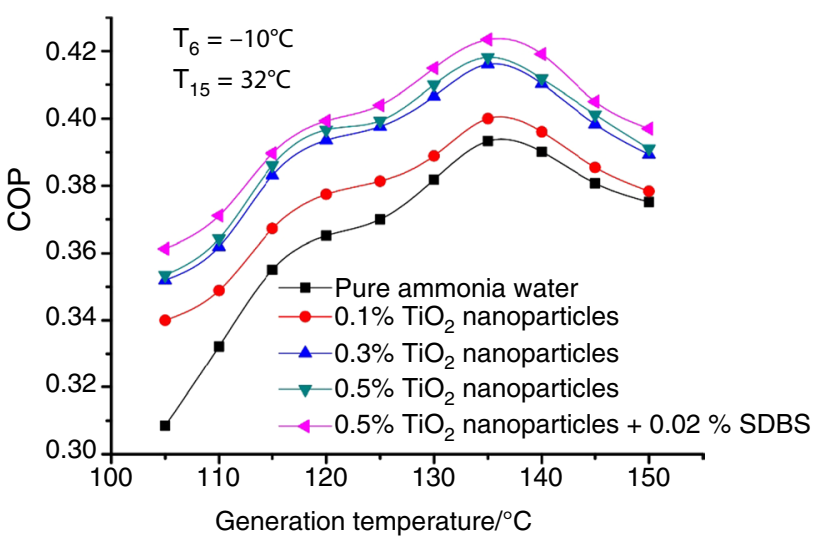

Fig. 22 The COP of AARS with different mass fractions of $\mathrm{TiO}_{2}$ [377]

used. Incidentally, the most common method for synthesising nanofluid is the worst performing method for ensuring fluid stability. Green synthesis techniques demonstrate sufficient promise in improving stability; however, the thermal performance of the green-synthesised nanofluids is not normally as high as nanofluids synthesised by the two-step technique. Furthermore, there appears no standard for reporting the stability of nanofluids. Therefore, a generic standard for measuring nanofluid stability must be developed so that easy comparisons can be made across nanofluid types.

Another significant challenge is the theoretical unpredictability of the thermophysical behaviour of nanofluids. While 
Table 12 Studies related to the application of nanofluids refrigeration systems

\begin{tabular}{llll}
\hline References & Nanofluid used & Type of study & Enhancement observed \\
\hline$[379]$ & $\mathrm{Al}_{2} \mathrm{O}_{3}, \mathrm{TiO}_{2}$, and a hybrid of $\mathrm{Al}_{2} \mathrm{O}_{3} /$ & Experiment & vapour compression refrigeration \\
& $\mathrm{TiO}_{2}$ water
\end{tabular}

Barocaloric regenerative refrigeration cycle

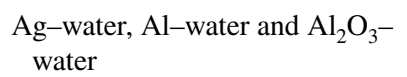

Acetone $/ \mathrm{ZnBr}_{2}-\mathrm{ZnO}$

$\mathrm{Al}_{2} \mathrm{O}_{3}$-POE oil

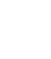

$$
\text { Antifreeze-CoFe }{ }_{2} \mathrm{O}_{4} / \mathrm{SiO}_{2}
$$

Graphene-acetone/ZnBr2
Key outcomes

$\mathrm{Al}_{2} \mathrm{O}_{3}$ /water contributed a higher coefficient of performance and a lower elapsed time for cooling the fluid of a chiller system. Higher values of the VCRS COP were obtained at lower values of air velocity of air conditioner and higher values of the nanofluid flow rate of the chiller unit. The $\mathrm{Al}_{2} \mathrm{O}_{3}$ / $\mathrm{H} 2 \mathrm{O}$ provided lower values of compression ratio and higher values of the refrigeration effect in comparison with $\mathrm{TiO}_{2} /$ water by approximately $4.1 \%$ and $5.3 \%$, respectively

The photothermal characteristics of the nanofluids for absorption refrigeration were studied. An increase in bulk temperature and surface evaporation rate of iron oxide-based nanofluids under solar simulator shows their efficient photo-tothermal energy conversion and the consequently enhanced vapourising ability. Both the sensible and latent heat capture were boosted for nanofluid

It was found that, in high volume fractions (e.g. 1\%), the viscosity increased by $10 \%$, which is small compared to the reported amounts for an increase in the viscosity of other nanofluids

The results reveal that, as a general trend, the effect of adding $10 \% \mathrm{Cu}$ nanoparticles in the water/ethylene-glycol mixture enhances heat transfer by as much as $30 \%$

The nanofluids cause changes by the increase in the temperature $\left(15-65^{\circ} \mathrm{C}\right)$ in most cases for the mass fraction increase by $37.7 \%$

A small proportion of nanoparticles can offer benefits by improved boiling at lower temperatures where the temperature potential above saturation reduces

The use of Ag-water was found to improve the system's efficiency from $77.3 \%$ to $81 \%$

The results indicate that converting the acetone $/ \mathrm{ZnBr}_{2}$ to a nanofluid provides a potential improvement on the performance of this fluid in the vapour absorption refrigeration system

Using $0.1 \%$ Al203 nanoparticle concentration, the COP of the system was improved by $17.27 \%$, and energy consumption was reduced by $32.48 \%$. 
Table 12 (continued)

\begin{tabular}{|c|c|c|c|c|}
\hline References & Nanofluid used & Type of study & Enhancement observed & Key outcomes \\
\hline$[387]$ & $\mathrm{CuO} / \mathrm{H}_{2} \mathrm{O}$ & Numerical & solar absorption chiller & $\begin{array}{l}\text { The application of the nano- } \\
\text { fluid enhanced the performance } \\
\text { of the NH3-NaSCN and NH3- } \\
\text { LiNO3 systems by } 2.70 \% \text { and } \\
1.50 \% \text {, respectively }\end{array}$ \\
\hline [388] & $\mathrm{TiO}_{2}-\mathrm{R} 600 \mathrm{a}$ nanorefrigerant & Experiment & Vapour compression refrigeration & $\begin{array}{l}\text { The highest refrigeration effect value } \\
\text { was } 290.83 \mathrm{~kJ} / \mathrm{kg} \text { for } \mathrm{R} 600 \mathrm{a}-\mathrm{TiO}_{2} \\
\text { mixture which also had the highest } \\
\text { COP value of } 4.99\end{array}$ \\
\hline
\end{tabular}

many studies settle for regression-based correlation models to predict thermophysical properties, intelligent computing has also been widely used in the predictions. It is the opinion of the authors that because of the almost infinite variables that affect the thermophysical behaviour of nanofluids, intelligent computing would be the most accurate predicting the thermophysical behaviour of nanofluids. Therefore, a generic standard must be developed for labelling data obtained from the experiments measuring thermophysical properties of nanofluids. Developing a global data bank will drastically improve the prediction accuracy of artificial neural network and machine learning models, saving unlimited research costs in conducting thermophysical behaviour measurements.

To improve numerical analysis models, further nanofluid heat transfer correlation studies are required for determining the Nusselt number correction equation. Many studies adopt the Nusselt number correlation equation proposed by Pak and Cho [392]; however, this model was developed for water, $\mathrm{Al}_{2} \mathrm{O}_{3}$-water and $\mathrm{TiO}_{2}$-water nanofluids and may not be particularly accurate for other nanofluids. More experiments using other nanofluids, especially for hybrid nanofluids, will further enlighten the field and improve the accuracy of numerical studies.

Finally, the classification of nanofluids must be improved. As nanofluid research increases, several unique types of fluids are synthesised. Previously, conventional fluid often implies fluids with a single-particle material, while hybrid nanofluid refers to a fluid with more than one nanoparticle material. However, it appears that further classifications are required as nanofluid have the potential to have an $n$th number of significant nanomaterials types present in the fluid. Some authors have sought to classify nanofluids with two significant nanomaterials type as "binary hybrid nanofluid" and nanofluids with three significant nanomaterials type as "ternary hybrid nanofluid". It may be beneficial if classifications are conducted along these lines.

\section{Conclusions and recommendations}

The use of nanofluids as coolants in heat transfer devices has gained attention over the years. This study presents a detailed review of studies relating to the preparation, thermophysical property measurements and application of nanofluids in a range of thermal devices requiring efficient heat transfer published in 2019. Some of the areas reviewed include thermophysical models used in determining the properties of the nanofluids, mechanisms that support the enhanced thermal behaviours of nanofluids, and the application of different nanofluids in devices such as solar collectors, heat exchangers, electronics cooling and thermal storage. Based on the articles reviewed in this study, the following recommendations are made:

On the preparation of nanofluids;

- Few studies on the preparation of nanofluids based on the one-step method are available, and this method has been proven to have better stability than the two-step method. More studies on the production of nanofluids using the one-step method are needed, as this could help in the development of more cost-effective means for the large-scale production of nanofluids.

Regarding the thermophysical properties of nanofluids:

- An increase in the nanoparticle volume concentration leads to a decrease in the specific heat capacity of nanofluids in cases where the heat capacity of base fluids is higher than those of nanoparticles. Since a higher heat capacity is needed in coolants, further studies are required to assess how this phenomenon can be improved.

- Many studies on the thermal behaviour of nanofluids were conducted for temperatures between 10 and $100{ }^{\circ} \mathrm{C}$. The interaction mechanism of nanoparticles in base fluids for heat transfer at higher temperatures (greater than $100{ }^{\circ} \mathrm{C}$ ) and cryogenic conditions requires further investigation. 
- There exist huge differences between the heat transfer predicted by the single-phase homogenous model and those obtained from experiments. More studies related to the development of other models (two-phase models) are required which allude to defining the conditions where the single-phase models can be applied to provide more accurate results.

- There has been an increase in both the number and methods for developing correlation models that predict the thermophysical properties of nanofluids. However, more correlation equations that predict the heat transfer (Nusselt number) and friction factor behaviours of many nanofluids are needed.

On studying the mechanisms that influenced the properties of nanofluids:

- Knowledge of the dominant forces responsible for the behaviour of nanorefrigerants in various flow configurations requires further development.

- An understanding of the impact of nanoparticle morphology (size and shape), nanoparticle mixture ratio (for hybrid nanofluids) on heat transfer augmentation is limited. More studies are needed to understand the impact of these on the performance of nanofluids in heat transfer devices.

Investigation on the various heat transfer devices:

- Further studies are required, as there are contrasting reports on the effect of nanoparticle loading on the pressure drop and additional pump power requirement. While some studies claim that the effect of particle loading increases the pressure drop and consequently the pump power requirement of the system, others argue that when the heat transfer rate obtained using nanofluids is compared with that of conventional fluids, the nanofluids lowers the pump power requirements.

- In heat exchangers and car radiators, the constant rate of heat transfer from the use of nanofluids leads to a reduction in the heat transfer surface. This can result in an improvement in the size and volume of these devices. Such improvements would lead to a reduction in the drag forces witnessed in vehicles and increase the performance of the engine.

- The most common model used in the literature for the simulation of nanofluids remains the finite volume method. Further studies using other methods are needed for the comparison of the different numerical approaches.

- Further studies on the effects of erosion of heat transfer and corrosion of flow channels resulting from the use of nanofluids, especially in high temperatures, are required. Both the short- and long-term impacts of sedimentation and nanoparticle deposition on the efficiency of heat transfer devices require investigation.

- Few studies are available on the production cost and environmental impact of nanofluids. Such factors present huge hurdles to the commercialisation of nanofluids.

- Further information on the effect of oxidisation of metallic nanoparticles used with phase change materials on the thermal performance of the thermal storage unit is required, especially during the melting phase.

Acknowledgements Open Access funding provided by the Qatar National Library.

Open Access This article is licensed under a Creative Commons Attribution 4.0 International License, which permits use, sharing, adaptation, distribution and reproduction in any medium or format, as long as you give appropriate credit to the original author(s) and the source, provide a link to the Creative Commons licence, and indicate if changes were made. The images or other third party material in this article are included in the article's Creative Commons licence, unless indicated otherwise in a credit line to the material. If material is not included in the article's Creative Commons licence and your intended use is not permitted by statutory regulation or exceeds the permitted use, you will need to obtain permission directly from the copyright holder. To view a copy of this licence, visit http://creativecommons.org/licenses/by/4.0/.

\section{References}

1. Incropera FP, Bergman TL, Lavine AS, DeWitt DP. Fundamentals of heat and mass transfer. New York: Springer; 2011.

2. Cengel YA, Boles MA. Thermodynamics: an engineering approach. 8th ed. New York: McGraw-Hill; 2015.

3. Cengel YA. Heat transfer: a practical approach. 2nd ed. New York: McGraw-Hill; 2002.

4. Zhao N, Li S, Yang J. A review on nanofluids: data-driven modeling of thermalphysical properties and the application in automotive radiator. Renew Sustain Energy Rev. 2016;66:596-616. https://doi.org/10.1016/j.rser.2016.08.029.

5. Krishna VM, Kumar MS. Numerical analysis of forced convective heat transfer of nanofluids in microchannel for cooling electronic equipment. Mater Today Proc. 2019;17:295-302. https:// doi.org/10.1016/j.matpr.2019.06.433.

6. Okonkwo EC, Okwose CF, Abid M, Ratlamwala TAH. Second-law analysis and exergoeconomics optimization of a solar tower-driven combined-cycle power plant using supercritical $\mathrm{CO}_{2}$. J Energy Eng ASCE. 2018;144(3):1-12. https://doi. org/10.1061/(ASCE)EY.1943-7897.0000534.

7. Okonkwo EC, Abid M, Ratlamwala TAH. Numerical analysis of heat transfer enhancement in a parabolic trough collector based on geometry modifications and working fluid usage. J Sol Energy Eng. 2018;140(5):0510091. https://doi.org/10.1115/1.4040076.

8. Meseguer J, Pérez-Grande I, Sanz-Andrés A. Spacecraft thermal control. 1st ed. London: Elsevier; 2012.

9. Sajid MU, Ali HM. Thermal conductivity of hybrid nanofluids: a critical review. Int J Heat Mass Transf. 2018;126:211-34. https ://doi.org/10.1016/j.ijheatmasstransfer.2018.05.021. 
10. Das SK, Choi SUS, Patel HE. Heat transfer in nanofluids-a review heat transfer in nanofluids. Heat Transf Eng. 2007;27(10):37-41. https://doi.org/10.1080/014576306009045 93.

11. Kaggwa A, Carson JK. Developments and future insights of using nanofluids for heat transfer enhancements in thermal systems: a review of recent literature. Int Nano Lett. 2019;9(4):277-88. https://doi.org/10.1007/s40089-019-00281-x.

12. Gupta M, Singh V, Kumar R, Said Z. A review on thermophysical properties of nanofluids and heat transfer applications. Renew Sustain Energy Rev. 2017;74(March):638-70. https://doi. org/10.1016/j.rser.2017.02.073.

13. Ganji DD, Sabzehmeidani Y, Sedighiamiri A. Nonlinear systems in heat transfer. New York: Elsevier; 2018.

14. Okonkwo EC, Wole-Osho I, Kavaz D, Abid M. Comparison of experimental and theoretical methods of obtaining the thermal properties of alumina/iron mono and hybrid nanofluids. J Mol Liq. 2019;292:111377. https://doi.org/10.1016/j.molli q.2019.111377.

15. Choi SUS, Eastman JA. Enhancing thermal conductivity of fluids with nanoparticles. In: American Society of Mechanical Engineers, Fluids Engineering Division (Publication) FED; 1995. vol. 231, pp. 99-105.

16. Sivashanmugam P. Application of nanofluids in heat transfer; 2012. vol. 1.

17. Maxwell JC. A treatise on electricity and magnetism [volume 2]. 2nd ed. London: Clarendon Press; 1881.

18. Ali N, Teixeira JA, Addali A. A review on nanofluids: fabrication, stability, and thermophysical properties. J Nanomater. 2018. https://doi.org/10.1155/2018/6978130.

19. Okonkwo EC, Essien EA, Akhayere E, Abid M, Kavaz D, Ratlamwala TAH. Thermal performance analysis of a parabolic trough collector using water-based green-synthesized nanofluids. Sol Energy. 2018;170:658-670. https://doi.org/10.1016/j.solen er.2018.06.012.

20. Menni Y, Chamkha AJ, Lorenzini G, Kaid N, Ameur H, Bensafi M. Advances of nanofluids in solar collectors-a review of numerical studies. Math Model Eng Probl. 2019;6(3):415-27. https://doi.org/10.18280/mmep.060313.

21. Wahab A, Hassan A, Qasim MA, Ali HM, Babar H, Sajid MU. Solar energy systems - potential of nanofluids. J Mol Liq. 2019;289:111049. https://doi.org/10.1016/j.molliq.2019.11104 9.

22. Ibrahim H, Sazali N, Shah ASM, Karim MSA, Aziz F, Salleh WNW. A review on factors affecting heat transfer efficiency of nanofluids for application in plate heat exchanger. J Adv Res Fluid Mech Therm Sci. 2019;60(1):144-54.

23. Sajid MU, Ali HM. Recent advances in application of nanofluids in heat transfer devices: a critical review. Renew Sustain Energy Rev. 2019;103:556-92. https://doi.org/10.1016/j. rser.2018.12.057.

24. Nazari MA, Ahmadi MH, Sadeghzadeh M, Shafii MB, Goodarzi M. A review on application of nanofluid in various types of heat pipes. J Cent South Univ. 2019;26:1021-41. https://doi. org/10.1007/s11771-019-4068-9.

25. Vele NS, Patil RK. Review on heat transfer enhancement in car radiator using Nano fluids. In: Proceedings of the International Conference on Industrial Engineering and Operations Management; 2019. pp. 527-537.

26. Ramezanizadeh M, Nazari MA, Ahmadi MH, Lorenzini G, Pop I. A review on the applications of intelligence methods in predicting thermal conductivity of nanofluids. J Therm Anal Calorim. 2019;138:827-43. https://doi.org/10.1007/s10973-019-08154-3.

27. Sezer N, Atieh MA, Koç M. A comprehensive review on synthesis, stability, thermophysical properties, and characterization of nanofluids. Powder Technol. 2019;344:404-31. https://doi. org/10.1016/j.powtec.2018.12.016.

28. Loni R, et al. Research and review study of solar dish concentrators with different nanofluids and different shapes of cavity receiver: experimental tests. Renew Energy. 2020;145:783-804. https://doi.org/10.1016/j.renene.2019.06.056.

29. Sahin AZ, Uddin MA, Yilbas BS, Al-Sharafi A. Performance enhancement of solar energy systems using nanofluids: an updated review. Renew Energy. 2020;145:1126-48. https://doi. org/10.1016/j.renene.2019.06.108.

30. Goel N, Taylor RA, Otanicar T. A review of nanofluid-based direct absorption solar collectors: design considerations and experiments with hybrid PV/Thermal and direct steam generation collectors. Renew Energy. 2020;145:903-13. https://doi. org/10.1016/j.renene.2019.06.097.

31. Borode A, Ahmed N, Olubambi P. A review of solar collectors using carbon-based nanofluids. J Clean Prod. 2019;241:118311. https://doi.org/10.1016/j.jclepro.2019.118311.

32. Abbas N, et al. Applications of nanofluids in photovoltaic thermal systems: a review of recent advances. Phys A Stat Mech Appl. 2019;536:122513. https://doi.org/10.1016/j.physa.2019.122513.

33. Pordanjani AH, Aghakhani S, Afrand M, Mahmoudi B, Mahian $\mathrm{O}$, Wongwises S. An updated review on application of nanofluids in heat exchangers for saving energy. Energy Convers Manag. 2019;198:111886. https://doi.org/10.1016/j.encon man.2019.111886.

34. Ahmadi MH, Ghazvini M, Sadeghzadeh M, Nazari MA, Ghalandari M. Utilization of hybrid nanofluids in solar energy applications: a review. Nano-Struct Nano-Objects. 2019;20:100386. https://doi.org/10.1016/j.nanoso.2019.100386.

35. Farhana K, et al. Improvement in the performance of solar collectors with nanofluids-a state-of-the-art review. Nano-Struct Nano-Objects. 2019;18:100276. https://doi.org/10.1016/j.nanos o.2019.100276.

36. Borode AO, Ahmed NA, Olubambi PA. A review of heat transfer application of carbon-based nanofluid in heat exchangers. NanoStruct Nano-Objects. 2019;20:100394. https://doi.org/10.1016/j. nanoso.2019.100394.

37. Nazari MA, Ghasempour R, Ahmadi MH. A review on using nanofluids in heat pipes. J Therm Anal Calorim. 2019;137(6):1847-55. https://doi.org/10.1007/s10973-01908094-y.

38. Cacua K, Buitrago-Sierra R, Herrera B, Pabón E, Murshed SMS. Nanofluids' stability effects on the thermal performance of heat pipes: a critical review. J Therm Anal Calorim. 2019;136(4):1597-614. https://doi.org/10.1007/s1097 3-018-7787-5.

39. Shah TR, Ali HM. Applications of hybrid nanofluids in solar energy, practical limitations and challenges: a critical review. Sol Energy. 2019;183:173-203. https://doi.org/10.1016/j.solen er.2019.03.012.

40. Bumataria RK, Chavda NK, Panchal H. Current research aspects in mono and hybrid nanofluid based heat pipe technologies. Heliyon. 2019. https://doi.org/10.1016/j.heliyon.2019.e01627.

41. Zayed ME, Zhao J, Du Y, Kabeel AE, Shalaby SM. Factors affecting the thermal performance of the flat plate solar collector using nanofluids: a review. Sol Energy. 2019;182:382-96. https://doi.org/10.1016/j.solener.2019.02.054.

42. Sakhaei SA, Valipour MS. Performance enhancement analysis of The flat plate collectors: a comprehensive review. Renew Sustain Energy Rev. 2019;102:186-204. https://doi.org/10.1016/j. rser.2018.11.014.

43. Razali NFM, Fudholi A, Ruslan MH, Sopian K. Review of waternanofluid based photovoltaic/thermal (PV/T) systems. Int J Electr Comput Eng. 2019;9(1):134. https://doi.org/10.11591/ijece.v9i1. 
44. Olia H, Torabi M, Bahiraei M, Ahmadi MH, Goodarzi M, Safaei MR. Application of nanofluids in thermal performance enhancement of parabolic trough solar collector: state-of-the-art. Appl Sci. 2019;9(3):463. https://doi.org/10.3390/app9030463.

45. Xian HW, Sidik NAC, Najafi G. Recent state of nanofluid in automobile cooling systems. J Therm Anal Calorim. 2019;135:9811008. https://doi.org/10.1007/s10973-018-7477-3.

46. Rasih RA, Sidik NAC, Samion S. Numerical investigation of direct absorption solar collector using nanofluids: a review. In: IOP Conference Series: Materials Science and Engineering; 2019. https://doi.org/10.1088/1757-899x/469/1/012059.

47. Bellos E, Tzivanidis C. A review of concentrating solar thermal collectors with and without nanofluids. J Therm Anal Calorim. 2019;135:763-86. https://doi.org/10.1007/s10973-018-7183-1.

48. Ramasamy D, Sudhakara RS, Ramachandran T, Gunasekharan S. A critical review on performance of various nanofluids in solar flat plate collector, heat exchanger and radiator. Int J Mech Prod Eng Res Dev. 2020;9:74-90.

49. Akram N, et al. A comprehensive review on nanofluid operated solar flat plate collectors. J Therm Anal Calorim. 2019. https:// doi.org/10.1007/s10973-019-08514-z.

50. Wang X, et al. A comprehensive review on the properties of nanofluid fuel and its additive effects to compression ignition engines. Appl Surf Sci. 2019;504(October):2019. https://doi. org/10.1016/j.apsusc.2019.144581.

51. Singh SK, Kumar A. An effect of twisted tape with nanofluid on the performance of double pipe heat exchanger: a comprehensive review. Int J Mech Prod Eng Res Dev. 2019;9(1):531-40. https:// doi.org/10.24247/ijmperdfeb201951.

52. Rasih RA, Sidik NAC, Samion S. Recent progress on concentrating direct absorption solar collector using nanofluids: a review. J Therm Anal Calorim. 2019;137:903-22. https://doi.org/10.1007/ s10973-018-7964-6.

53. Manikandan GK, Iniyan S, Goic R. Enhancing the optical and thermal efficiency of a parabolic trough collector-a review. Appl Energy. 2019;235:1524-40. https://doi.org/10.1016/j.apene rgy.2018.11.048.

54. Sopian K, Alwaeli AHA, Kazem HA. Advanced photovoltaic thermal collectors. Proc Inst Mech Eng Part E J Process Mech Eng. 2019. https://doi.org/10.1177/0954408919869541.

55. Kumar A, Subudhi S. Preparation, characterization and heat transfer analysis of nanofluids used for engine cooling. Appl Therm Eng. 2019;160:114092. https://doi.org/10.1016/j.applt hermaleng.2019.114092.

56. Qiu L, Ouyang Y, Feng Y, Zhang X. Review on micro/nano phase change materials for solar thermal applications. Renew Energy. 2019;145:650-7. https://doi.org/10.1016/j.renen e.2019.03.088

57. Mashali F, et al. International journal of heat and mass transfer thermo-physical properties of diamond nanofluids: a review. Int J Heat Mass Transf. 2019;129:1123-35. https://doi.org/10.1016/j. ijheatmasstransfer.2018.10.033.

58. Babar H. Towards hybrid nano fluids : preparation, thermophysical properties. Appl Chall. 2019;281:598-633.

59. Asadi A, et al. Recent advances in preparation methods and thermophysical properties of oil-based nano fluids: a state-ofthe-art review. Powder Technol. 2019;352:209-26. https://doi. org/10.1016/j.powtec.2019.04.054.

60. Asadi A, Pourfattah F, Miklós I, Afrand M. Ultrasonics-sonochemistry effect of sonication characteristics on stability, thermophysical properties, and heat transfer of nanofluids : a comprehensive review. Ultrason Sonochem. 2019;58:104701. https ://doi.org/10.1016/j.ultsonch.2019.104701.

61. Yu W, Xie H. A review on nanofluids: preparation, stability mechanisms, and applications. J Nanomater. 2012;87:228-40. https://doi.org/10.1155/2012/435873.
62. Asadi A, Alarifi IM, Ali V, Nguyen HM. An experimental investigation on the effects of ultrasonication time on stability and thermal conductivity of MWCNT-water nanofluid: Finding the optimum ultrasonication time. Ultrason Sonochem. 2019;58:104639. https://doi.org/10.1016/j.ultsonch.2019.10463 9 .

63. Chen W, Zou C, Li X. Application of large-scale prepared MWCNTs nanofluids in solar energy system as volumetric solar absorber. Sol Energy Mater Sol Cells. 2019;200(8):109931. https ://doi.org/10.1016/j.solmat.2019.109931.

64. Almanassra IW, Manasrah AD, Al-Mubaiyedh UA, Al-Ansari T, Malaibari ZO, Atieh MA. An experimental study on stability and thermal conductivity of water/CNTs nanofluids using different surfactants: a comparison study. J Mol Liq. 2019. https://doi. org/10.1016/j.molliq.2019.111025.

65. Liu WI, et al. A novel comprehensive experimental study concerned graphene oxide nanoparticles dispersed in water: synthesise, characterisation, thermal conductivity measurement and present a new approach of RLSF neural network. Int Commun Heat Mass Transf. 2019;109:104333. https://doi.org/10.1016/j. icheatmasstransfer.2019.104333.

66. Aureen Albert A, Harris Samuel DG, Parthasarathy V, Kiruthiga $\mathrm{K}$. A facile one pot synthesis of highly stable PVA-CuO hybrid nanofluid for heat transfer application. Chem Eng Commun. 2019. https://doi.org/10.1080/00986445.2019.1588731.

67. Yang L, Huang J, Ji W, Mao M. Investigations of a new combined application of nanofluids in heat recovery and air purification. Powder Technol. 2019. https://doi.org/10.1016/j.powte c.2019.10.053.

68. Huang J, et al. Facile preparation and thermal properties of Field's alloy nanofluid for heat transfer. Coll Surf A Physicochem Eng Asp. 2019;581:123805. https://doi.org/10.1016/j.colsu rfa.2019.123805.

69. Du B, Jian Q. Size controllable synthesis of graphene water nanofluid with enhanced stability. Fullerenes Nanotub Carbon Nanostruct. 2019;27(1):87-96. https://doi.org/10.1080/15363 83X.2018.1529667.

70. Li D, Fang W, Feng Y, Geng Q, Song M. Stability properties of water-based gold and silver nanofluids stabilized by cationic gemini surfactants. J Taiwan Inst Chem Eng. 2019;97:458-65. https://doi.org/10.1016/j.jtice.2019.02.017.

71. Rostami S, Nadooshan AA, Raisi A. An experimental study on the thermal conductivity of new antifreeze containing copper oxide and graphene oxide nano-additives. Powder Technol. 2019;345:658-67. https://doi.org/10.1016/j.powtec.2019.01.055.

72. Nithiyanantham U, Grosu Y, González-Fernández L, Zaki A, Igartua JM, Faik A. Development of molten nitrate salt based nanofluids for thermal energy storage application: high thermal performance and long storage components life-time. AIP Conf Proc. 2019. https://doi.org/10.1063/1.5117740.

73. Mahyari AA, Karimipour A, Afrand M. Effects of dispersed added graphene oxide-silicon carbide nanoparticles to present a statistical formulation for the mixture thermal properties. Phys A Stat Mech Appl. 2019;521:98-112. https://doi.org/10.1016/j. physa.2019.01.035.

74. Palanisamy K, Kumar PCM. Experimental investigation on convective heat transfer and pressure drop of cone helically coiled tube heat exchanger using carbon nanotubes/water nanofluids. Heliyon. 2019;5:e01705. https://doi.org/10.1016/j.heliyon.2019. e01705.

75. Kiaee FM, Bahrami Z, Hormozi F. Experimental investigation on the thermal performance and new correlation for thermal conductivity of aqueous copper oxide-doped MCM-41 nanofluids. J Therm Anal Calorim. 2019. https://doi.org/10.1007/s10973-01908832-2. 
76. Gulzar O, Qayoum A, Gupta R. Experimental study on stability and rheological behaviour of hybrid $\mathrm{Al}_{2} \mathrm{O}_{3}-\mathrm{TiO}_{2}$ Therminol-55 nanofluids for concentrating solar collectors. Powder Technol. 2019;352:436-44. https://doi.org/10.1016/j.powtec.2019.04.060.

77. Prasad TR, Krishna KR, Sharma KV. Experimental testing of thermo physical properties of novel water and glycerol mixture-based silica nano fluids. Int J Recent Technol Eng. 2019;8(2):5299-305. https://doi.org/10.35940/ijrte.b1086.07821 9.

78. Bin-Abdun NA, et al. Heat transfer improvement in simulated small battery compartment using metal oxide $(\mathrm{CuO}) /$ deionized water nanofluid. Heat Mass Transf Stoffuebertragung. 2019. https ://doi.org/10.1007/s00231-019-02719-6.

79. Taghizadeh A, Taghizadeh M, Azimi M, Alsagri AS, Alrobaian AA, Afrand M. Influence of cerium oxide nanoparticles on thermal conductivity of antifreeze: preparation and stability of nanofluid using surfactant. J Therm Anal Calorim. 2019. https ://doi.org/10.1007/s10973-019-08422-2.

80. Liu J, Wang N, Song Y, Yang B. Influence of single and multiple coupling factors on the stability of paraffin-based nanofluids. Heat Mass Transf Stoffuebertragung. 2019. https://doi. org/10.1007/s00231-019-02715-w.

81. Rukman NSB, Fudholi A, Razali NFM, Ruslan MH, Sopian K. Investigation of $\mathrm{TiO}_{2}$ and MWCNT nanofluids-based photovoltaic-thermal (PV/T) system. IOP Conf Ser Earth Environ Sci. 2019. https://doi.org/10.1088/1755-1315/268/1/012076.

82. Syarif DG, Prajitno DH, Pane JS. Nanofluids with enhanced CHF prepared from self-combustion synthesized $\mathrm{Al}_{2} \mathrm{O}_{3}$ nanoparticles with PEG 1000 as fuel. IOP Conf Ser Mater Sci Eng. 2019. https ://doi.org/10.1088/1757-899x/515/1/012046.

83. Kharat PB, Kounsalye JS, Shisode MV, Jadhav KM. Preparation and thermophysical investigations of $\mathrm{CoFe}_{2} \mathrm{O}_{4}$-based Nanofluid: a potential heat transfer agent. J Supercond Nov Magn. 2019;32(2):341-51. https://doi.org/10.1007/s10948-018-4711-y.

84. Wang C, Zhang X, Jia W, Deng Q, Leng Y. Preparation and tribological properties of modified field's alloy nanoparticles as additives in liquid poly-alfa-olefin solution. J Tribol. 2019. https ://doi.org/10.1115/1.4042768.

85. Barai DP, Bhanvase BA, Saharan VK. reduced graphene oxide$\mathrm{Fe}_{3} \mathrm{O}_{4}$ nanocomposite based nanofluids: study on ultrasonic assisted synthesis, thermal conductivity, rheology, and convective heat transfer. Ind Eng Chem Res. 2019;58(19):8349-69. https://doi.org/10.1021/acs.iecr.8b05733.

86. Afzal A, Khan SA, Saleel CA. Role of ultrasonication duration and surfactant on characteristics of $\mathrm{ZnO}$ and $\mathrm{CuO}$ nanofluids. Mater Res Express. 2019. https://doi.org/10.1088/2053-1591/ ab5013.

87. Nithiyanantham U, Zaki A, Grosu Y, González-Fernández L, Igartua JM, Faik A. $\mathrm{SiO}_{2}$ and $\mathrm{Al}_{2} \mathrm{O}_{3}$ core-shell nanoparticles based molten salts nanofluids for thermal energy storage applications. J Energy Storage. 2019;26:101033. https://doi. org/10.1016/j.est.2019.101033.

88. Abadeh A, Passandideh-Fard M, Maghrebi MJ, Mohammadi M. Stability and magnetization of $\mathrm{Fe}_{3} \mathrm{O}_{4}$ /water nanofluid preparation characteristics using Taguchi method. J Therm Anal Calorim. 2019;135(2):1323-34. https://doi.org/10.1007/s1097 3-018-7662-4.

89. Mahbubul IM, Elcioglu EB, Amalina MA, Saidur R. Stability, thermophysical properties and performance assessment of alumina-water nanofluid with emphasis on ultrasonication and storage period. Powder Technol. 2019;345:668-75. https://doi. org/10.1016/j.powtec.2019.01.041.

90. Warjri M, Narayan J. Synthesis, characterization and physicochemical properties of cupric oxide nanoparticles and their nanofluids. Mater Today Proc. 2019;18:1176-84. https://doi. org/10.1016/j.matpr.2019.06.578.
91. Nazarzade S, Ghorbani HR, Jafarpourgolroudbary H. Synthesis, preparation and the experimental study of silver/water nanofluid to optimize convective heat transfer in a shell and tube heat exchanger. Inorg Nano-Metal Chem. 2019;49(6):173-6. https:// doi.org/10.1080/24701556.2019.1606827.

92. Prasad TR, Konijeti R, Sharma KV. The experimental investigation and comparison of thermal conductivities of cobalt and silica nano fluids in glycerol water mixture as base fluid. Int $\mathrm{J}$ Innov Technol Explor Eng. 2019;8(7):1614-21.

93. Chen Z, Shahsavar A, Al-Rashed AAAA, Afrand M. The impact of sonication and stirring durations on the thermal conductivity of alumina-liquid paraffin nanofluid: an experimental assessment. Powder Technol. 2019. https://doi.org/10.1016/j.powte c.2019.11.036

94. Esmaeili E, Rounaghi SA, Gruner W, Eckert J. The preparation of surfactant-free highly dispersed ethylene glycol-based aluminum nitride-carbon nanofluids for heat transfer application. Adv Powder Technol. 2019;30(10):2032-41. https://doi.org/10.1016/j. apt.2019.06.008.

95. Prasad TR, Krishna KR, Sharma KV. The stability and thermal conductivity of cobalt nano fluids in base liquid water and glycerol mixture. Int J Recent Technol Eng. 2019;8(3):8871-6. https ://doi.org/10.35940/ijrte.c6676.098319.

96. Mohammed HI, Giddings D, Walker GS. Thermo-physical properties of the nano-binary fluid (acetone-zinc bromide- $\mathrm{ZnO}$ ) as a low temperature operating fluid for use in an absorption refrigeration machine. Heat Mass Transf Stoffuebertragung. 2019. https://doi.org/10.1007/s00231-019-02760-5.

97. Graves JE, Latvytė E, Greenwood A, Emekwuru NG. Ultrasonic preparation, stability and thermal conductivity of a capped copper-methanol nanofluid. Ultrason Sonochem. 2019;55(January):25-31. https://doi.org/10.1016/j.ultsonch.2019.02.028.

98. Paul G, Chopkar M, Manna I, Das PK. Techniques for measuring the thermal conductivity of nanofluids: a review. Renew Sustain Energy Rev. 2010;14(7):2010. https://doi.org/10.1016/j. rser.2010.03.017.

99. Healy JJ, De Groot JJ, Kestin J. The theory of the transient hot-wire method for measuring thermal conductivity. Phys B + C. 1976;82(2):392-408. https://doi.org/10.1016/03784363(76)90203-5.

100. Einstein A. Paper 1. A new determination of molecular dimensions. Zurich: University of Zurich; 1905.

101. Koca HD, Doganay S, Turgut A, Tavman IH, Saidur R, Mahbubul IM. Effect of particle size on the viscosity of nanofluids: a review. Renew Sustain Energy Rev. 2018. https://doi. org/10.1016/j.rser.2017.07.016.

102. Mooney M. The viscosity of a concentrated suspension of spherical particles. J Colloid Sci. 1951. https://doi.org/10.1016/00958522(51)90036-0.

103. Krieger IM, Dougherty TJ. A mechanism for non-newtonian flow in suspensions of rigid spheres. Trans Soc Rheol. 1959. https:// doi.org/10.1122/1.548848.

104. Nielsen LE. Generalized equation for the elastic moduli of composite materials. J Appl Phys. 1970. https://doi. org/10.1063/1.1658506.

105. Batchelor GK. The effect of Brownian motion on the bulk stress in a suspension of spherical particles. J Fluid Mech. 1977;83(01):97. https://doi.org/10.1017/S0022112077001062.

106. Bruggeman VDAG. Berechnung verschiedener physikalischer Konstanten von heterogenen Substanzen. Ann Phys. 1935;5(24):636-64. https://doi.org/10.1002/andp.19354160705.

107. Hamilton RL, Crosser OK. Thermal conductivity of heterogeneous two-component systems. Ind Eng Chem Fundam. 1962;1(3):187-91. https://doi.org/10.1021/1160003a005. 
108. Mahian O, et al. Recent advances in modeling and simulation of nanofluid flows—part II: applications. Phys Rep. 2019;791:1-59. https://doi.org/10.1016/j.physrep.2018.11.003.

109. Dadhich M, Prajapati OS, Rohatgi N. Flow boiling heat transfer analysis of $\mathrm{Al}_{2} \mathrm{O}_{3}$ and $\mathrm{TiO}_{2}$ nanofluids in horizontal tube using artificial neural network (ANN). J Therm Anal Calorim. 2020;139(5):3197-217. https://doi.org/10.1007/s10973-01908674-y.

110. Yang L, Ji W, Mao M, Huang J. Dynamic stability, sedimentation, and time-dependent heat transfer characteristics of $\mathrm{TiO}_{2}$ and CNT nanofluids. J Therm Anal Calorim. 2019. https://doi. org/10.1007/s10973-019-09103-w.

111. Hameed MS, Suresh S, Singh RK. Comparative study of heat transfer and friction characteristics of water-based Alumina-copper and Alumina-CNT hybrid nanofluids in laminar flow through pipes. J Therm Anal Calorim. 2019;136(1):243-53. https://doi. org/10.1007/s10973-018-7898-z.

112. Yu W, France DM, Routbort JL, Choi SUS. Review and comparison of nanofluid thermal conductivity and heat transfer enhancements. Heat Transf Eng. 2008;29(5):432-60. https:// doi.org/10.1080/01457630701850851.

113. Esfe MH, Afrand M. An updated review on the nanofluids characteristics. J Therm Anal Calorim. 2019;138(6):4091-101. https ://doi.org/10.1007/s10973-019-08406-2.

114. Akhgar A, Toghraie D, Sina N, Afrand M. Developing dissimilar artificial neural networks (ANNs) to prediction the thermal conductivity of MWCNT-TiO $/ 2$ Water-ethylene glycol hybrid nano fluid. Powder Technol. 2019;355:602-10. https://doi. org/10.1016/j.powtec.2019.07.086.

115. Alarifi IM, Nguyen HM, Bakhtiyari AN, Asadi A. Feasibility of ANFIS-PSO and ANFIS-GA models in predicting thermophysical properties of $\mathrm{Al}_{2} \mathrm{O}_{3}$-MWCNT/Oil hybrid nanofluid. Materials (Basel). 2019;12(21):3628. https://doi.org/10.3390/ma12213628

116. Moldoveanu GM, Minea AA, Huminic G, Huminic A. $\mathrm{Al}_{2} \mathrm{O}_{3}$ / $\mathrm{TiO}_{2}$ hybrid nanofluids thermal conductivity. J Therm Anal Calorim. 2019;137(2):583-92. https://doi.org/10.1007/s1097 3-018-7974-4.

117. Essajai R, Tabtab I, Mzerd A, Mounkachi O, Hassanain N, Qjani M. Molecular dynamics study of thermal properties of nanofluids composed of one-dimensional (1-D) network of interconnected gold nanoparticles. Results Phys. 2019;15(2019):102576. https ://doi.org/10.1016/j.rinp.2019.102576.

118. Rehman WU, et al. Synthesis, characterization, stability and thermal conductivity of multi-walled carbon nanotubes (MWCNTs) and eco-friendly jatropha seed oil based nanofluid: an experimental investigation and modeling approach. J Mol Liq. 2019;293(2019):111534. https://doi.org/10.1016/j.molli q.2019.111534.

119. Khalifeh A, Vaferi B. Intelligent assessment of effect of aggregation on thermal conductivity of nanofluids-comparison by experimental data and empirical correlations. Thermochim Acta. 2019;681(2019):178377. https://doi.org/10.1016/j. tca.2019.178377.

120. Mirsaeidi AM, Yousefi F. Viscosity, thermal conductivity and density of carbon quantum dots nanofluids: an experimental investigation and development of new correlation function and ANN modeling. J Therm Anal Calorim. 2019. https://doi. org/10.1007/s10973-019-09138-z.

121. Motlagh SY, Sharifi A, Ahmadi M, Badfar H. Presentation of new thermal conductivity expression for $\mathrm{Al}_{2} \mathrm{O}_{3}$-water and $\mathrm{CuO}$-water nanofluids using gene expression programming (GEP). J Therm Anal Calorim. 2019;135(1):195-206. https://doi.org/10.1007/ s10973-018-7305-9.

122. Mousavi SM, Esmaeilzadeh F, Wang XP. Effects of temperature and particles volume concentration on the thermophysical properties and the rheological behavior of $\mathrm{CuO} / \mathrm{MgO} / \mathrm{TiO}_{2}$ aqueous ternary hybrid nanofluid: experimental investigation. J Therm Anal Calorim. 2019;137(3):879-901. https://doi. org/10.1007/s10973-019-08006-0.

123. Taherialekouhi R, Rasouli S, Khosravi A. An experimental study on stability and thermal conductivity of water-graphene oxide/ aluminum oxide nanoparticles as a cooling hybrid nanofluid. Int J Heat Mass Transf. 2019;145(2019):118751. https://doi. org/10.1016/j.ijheatmasstransfer.2019.118751.

124. Akilu S, Baheta AT, Chowdhury S, Padmanabhan E, Sharma KV. Thermophysical profile of $\mathrm{SiC}-\mathrm{CuO} / \mathrm{C}$ nanocomposite in base liquid ethylene glycol. Powder Technol. 2019;354(2019):540-51. https://doi.org/10.1016/j.powtec.2019.04.061.

125. Shahsavar A, Godini A, Sardari PT, Toghraie D, Salehipour $\mathrm{H}$. Impact of variable fluid properties on forced convection of $\mathrm{Fe} 3 \mathrm{O} 4 / \mathrm{CNT} /$ water hybrid nanofluid in a double-pipe mini-channel heat exchanger. J Therm Anal Calorim. 2019;137(3):103143. https://doi.org/10.1007/s10973-018-07997-6.

126. Arani AAA, Pourmoghadam F. Experimental investigation of thermal conductivity behavior of MWCNTS-A12O3/ethylene glycol hybrid Nanofluid: providing new thermal conductivity correlation. Heat Mass Transf Stoffuebertragung. 2019;55(8):232939. https://doi.org/10.1007/s00231-019-02572-7.

127. Khan AI, et al. Experimental investigation of thermal conductivity and stability of $\mathrm{TiO}_{2}-\mathrm{Ag} /$ water nanocomposite fluid with SDBS and SDS surfactants. Thermochim Acta. 2019;678:178308. https://doi.org/10.1016/j.tca.2019.178308.

128. Rubasingh BJ, Selvakumar P, Raja RSS. Predicting thermal conductivity behaviour of $\mathrm{ZnO}, \mathrm{TiO}_{2}$ and ball milled $\mathrm{TiO}_{2} / \mathrm{ZnO}$ based nanofluids with ethylene glycol as base fluid. Mater Res Express. 2019;6(9):095702. https://doi.org/10.1088/2053-1591/ ab2bc5.

129. Sulgani MT, Karimipour A. Improve the thermal conductivity of $10 \mathrm{w} 40$-engine oil at various temperature by addition of $\mathrm{Al}_{2} \mathrm{O}_{3} /$ $\mathrm{Fe}_{2} \mathrm{O}_{3}$ nanoparticles. J Mol Liq. 2019;283:660-6. https://doi. org/10.1016/j.molliq.2019.03.140.

130. Mousavi SM, Esmaeilzadeh F, Wang XP. A detailed investigation on the thermo-physical and rheological behavior of $\mathrm{MgO} / \mathrm{TiO}$ 2 aqueous dual hybrid nanofluid. J Mol Liq. 2019;282:323-39. https://doi.org/10.1016/j.molliq.2019.02.100.

131. De Oliveira LR, Ribeiro SRFL, Reis MHM, Cardoso VL, Filho EPB. Experimental study on the thermal conductivity and viscosity of ethylene glycol-based nanofluid containing diamond-silver hybrid material. Diam Relat Mater. 2019;96:216-30. https://doi. org/10.1016/j.diamond.2019.05.004.

132. Wole-Osho I, Okonkwo EC, Adun H, Kavaz D, Abbasoglu S. An intelligent approach to predicting the effect of nanoparticle mixture ratio, concentration, and temperature on thermal conductivity of hybrid nanofluids. J Therm Anal Calorim. 2020;15:459. https://doi.org/10.1007/s10973-020-09594-y

133. Ahmed W, et al. Experimental investigation of convective heat transfer growth on ZnO@TiO2/DW binary composites/hybrid nanofluids in a circular heat exchanger. J Therm Anal Calorim. 2020. https://doi.org/10.1007/s10973-020-09363-x.

134. Giwa SO, Sharifpur M, Goodarzi M, Alsulami H, Meyer JP. Influence of base fluid, temperature, and concentration on the thermophysical properties of hybrid nanofluids of alumina-ferrofluid: experimental data, modeling through enhanced ANN, ANFIS, and curve fitting. J Therm Anal Calorim. 2020. https:// doi.org/10.1007/s10973-020-09372-w.

135. Pourrajab R, Noghrehabadi A, Behbahani M, Hajidavalloo E. An efficient enhancement in thermal conductivity of water-based hybrid nanofluid containing MWCNTs-COOH and Ag nanoparticles: experimental study. J Therm Anal Calorim. 2020. https:// doi.org/10.1007/s10973-020-09300-y. 
136. Izadkhah MS, Heris SZ. Influence of $\mathrm{Al}_{2} \mathrm{O}_{3}$ nanoparticles on the stability and viscosity of nanofluids: Insights from molecular dynamics simulation. J Therm Anal Calorim. 2019;138(1):62331. https://doi.org/10.1007/s10973-019-08228-2.

137. Dehghani Y, Abdollahi A, Karimipour A. Experimental investigation toward obtaining a new correlation for viscosity of $\mathrm{WO}_{3}$ and $\mathrm{Al}_{2} \mathrm{O}_{3}$ nanoparticles-loaded nanofluid within aqueous and nonaqueous basefluids. J Therm Anal Calorim. 2019;135(1):713-28. https://doi.org/10.1007/s10973-018-7394-5.

138. Ye X, Kandlikar SG, Li C. Viscosity of nanofluids containing anisotropic particles: a critical review and a comprehensive model. Eur Phys J E. 2019;42(12):60-5. https://doi.org/10.1140/ epje/i2019-11923-7.

139. Bahrami M, Akbari M, Bagherzadeh SA, Karimipour A, Afrand M, Goodarzi M. Develop 24 dissimilar ANNs by suitable architectures \& training algorithms via sensitivity analysis to better statistical presentation: measure MSEs between targets and ANN for $\mathrm{Fe}-\mathrm{CuO} / \mathrm{Eg}-$ Water nanofluid. Phys A Stat Mech Appl. 2019;519(2019):159-68. https://doi.org/10.1016/j.physa .2018.12.031

140. Ruhani B, Toghraie D, Hekmatifar M, Hadian M. Statistical investigation for developing a new model for rheological behavior of $\mathrm{ZnO}-\mathrm{Ag}$ (50\%-50\%)/Water hybrid Newtonian nanofluid using experimental data. Phys A Stat Mech Appl. 2019;525(2019):741-51. https://doi.org/10.1016/j.physa 2019.03.118.

141. Mousavi SB, Heris SZ, Hosseini MG. Experimental investigation of MoS2/diesel oil nanofluid thermophysical and rheological properties. Int Commun Heat Mass Transf. 2019;108:104298. https://doi.org/10.1016/j.icheatmasstransfer.2019.104298.

142. Hameed A, et al. Experimental investigation on synthesis, characterization, stability, thermo-physical properties and rheological behavior of MWCNTs-kapok seed oil based nanofluid. J Mol Liq. 2019;277(2019):812-24. https://doi.org/10.1016/j.molli q.2019.01.012.

143. Aghahadi MH, Niknejadi M, Toghraie D. An experimental study on the rheological behavior of hybrid Tungsten oxide $\left(\mathrm{WO}_{3}\right)$-MWCNTs/engine oil Newtonian nanofluids. J Mol Struct. 2019;1197(2019):497-507. https://doi.org/10.1016/j. molstruc.2019.07.080.

144. Alarifi IM, Alkouh AB, Ali V, Nguyen HM, Asadi A. On the rheological properties of MWCNT-TiO 2 /oil hybrid nanofluid: an experimental investigation on the effects of shear rate, temperature, and solid concentration of nanoparticles. Powder Technol. 2019;355(2019):157-62. https://doi.org/10.1016/j. powtec.2019.07.039.

145. Esfe MH, Abad ATK, Fouladi M. Effect of suspending optimized ratio of nano-additives MWCNT- $\mathrm{Al}_{2} \mathrm{O}_{3}$ on viscosity behavior of 5W50. J Mol Liq. 2019;285:572-85. https://doi. org/10.1016/j.molliq.2019.04.043.

146. Esfe MH, Esfandeh S, Niazi S. An experimental investigation, sensitivity analysis and RSM analysis of MWCNT(10)$\mathrm{ZnO}(90) / 10 \mathrm{~W} 40$ nanofluid viscosity. J Mol Liq. 2019;288:111020. https://doi.org/10.1016/j.molliq.2019.11102 0.

147. Esfe MH, Emami MRS, Amiri MK. Experimental investigation of effective parameters on MWCNT- $\mathrm{TiO}_{2} / \mathrm{SAE} 50$ hybrid nanofluid viscosity. J Therm Anal Calorim. 2019;137(3):743-57. https://doi.org/10.1007/s10973-018-7986-0.

148. Goodarzi M, Toghraie D, Reiszadeh M, Afrand M. Experimental evaluation of dynamic viscosity of ZnO-MWCNTs/engine oil hybrid nanolubricant based on changes in temperature and concentration. J Therm Anal Calorim. 2019;136(2019):513-25. https://doi.org/10.1007/s10973-018-7707-8.

149. Kumar V, Sahoo RR. Viscosity and thermal conductivity comparative study for hybrid nanofluid in binary base fluids. Heat
Transf Asian Res. 2019;48(7):3144-61. https://doi.org/10.1002/ htj. 21535 .

150. Talebizadehsardari P, Shahsavar A, Toghraie D, Barnoon P. An experimental investigation for study the rheological behavior of water-carbon nanotube/magnetite nanofluid subjected to a magnetic field. Phys A Stat Mech Appl. 2019;534(2019):122129. https://doi.org/10.1016/j.physa.2019.122129.

151. Vallejo JP, Sani E, Żyła G, Lugo L. Tailored silver/graphene nanoplatelet hybrid nanofluids for solar applications. J Mol Liq. 2019;296(2019):112007. https://doi.org/10.1016/j.molli q.2019.112007.

152. Wole-Osho I, Okonkwo EC, Kavaz D, Abbasoglu S. An experimental investigation into the effect of particle mixture ratio on specific heat capacity and dynamic viscosity of $\mathrm{Al}_{2} \mathrm{O}_{3}-\mathrm{ZnO}$ hybrid nanofluids. Powder Technol. 2020;363:699-716. https:// doi.org/10.1016/j.powtec.2020.01.015.

153. Moldoveanu GM, Minea AA. Specific heat experimental tests of simple and hybrid oxide-water nanofluids: proposing new correlation. J Mol Liq. 2019;279:299-305. https://doi.org/10.1016/j. molliq.2019.01.137.

154. Li Y, et al. Experimental study on the effect of $\mathrm{SiO}_{2}$ nanoparticle dispersion on the thermophysical properties of binary nitrate molten salt. Sol Energy. 2019;183(2019):776-81. https://doi. org/10.1016/j.solener.2019.03.036.

155. Hassan MA, Banerjee D. A soft computing approach for estimating the specific heat capacity of molten salt-based nanofluids. J Mol Liq. 2019;281(2019):365-75. https://doi.org/10.1016/j.molli q.2019.02.106.

156. Alade IO, Rahman MAA, Saleh TA. Predicting the specific heat capacity of alumina/ethylene glycol nanofluids using support vector regression model optimized with Bayesian algorithm. Sol Energy. 2019;183:74-82. https://doi.org/10.1016/j.solen er.2019.02.060.

157. Marcos MA, et al. MWCNT in PEG-400 nanofluids for thermal applications: a chemical, physical and thermal approach. J Mol Liq. 2019;294:111616. https://doi.org/10.1016/j.molli q.2019.111616.

158. Qiu L, et al. A review of recent advances in thermophysical properties at the nanoscale: from solid state to colloids. Phys Rep. 2020;843:1-81. https://doi.org/10.1016/j.physrep.2019.12.001.

159. Xuan Y, Li WHQ. Aggregation structure and thermal conductivity of nanofluids. AIChE J. 2003;49(4):1038-43.

160. Lee $\mathrm{JH}$, et al. Effective viscosities and thermal conductivities of aqueous nanofluids containing low volume concentrations of A12O3 nanoparticles. Int J Heat Mass Transf. 2008;51:2651-6. https://doi.org/10.1016/j.ijheatmasstransfer.2007.10.026.

161. Afzal A, Nawfal I, Mahbubul IM, Kumbar SS. An overview on the effect of ultrasonication duration on different properties of nanofluids. J Therm Anal Calorim. 2019;135(1):393-418. https ://doi.org/10.1007/s10973-018-7144-8.

162. Cacua K, Murshed SMS, Pabón E, Buitrago R. Dispersion and thermal conductivity of $\mathrm{TiO}_{2}$ /water nanofluid: effects of ultrasonication, agitation and temperature. J Therm Anal Calorim. 2020;140(1):109-14. https://doi.org/10.1007/s10973-019-08817 -1 .

163. Wang J, Li G, Li T, Zeng M, Sundén B. Effect of various surfactants on stability and thermophysical properties of nanofluids. J Therm Anal Calorim. 2020. https://doi.org/10.1007/s1097 3-020-09381-9.

164. Cakmak NK. The impact of surfactants on the stability and thermal conductivity of graphene oxide de-ionized water nanofluids. J Therm Anal Calorim. 2020;139(3):1895-902. https://doi. org/10.1007/s10973-019-09096-6.

165. Asadi A, et al. Effect of sonication characteristics on stability, thermophysical properties, and heat transfer of 
nanofluids: a comprehensive review. Ultrason Sonochem. 2019;58(2019):104701. https://doi.org/10.1016/j.ultso nch.2019.104701.

166. Khan AI, Arasu AV. A review of influence of nanoparticle synthesis and geometrical parameters on thermophysical properties and stability of nanofluids. Therm Sci Eng Progress. 2019. https ://doi.org/10.1016/j.tsep.2019.04.010.

167. Yang L, Ji W, Huang JN, Xu G. An updated review on the influential parameters on thermal conductivity of nano-fluids. J Mol Liq. 2019;296:111780. https://doi.org/10.1016/j.molli q.2019.111780.

168. Yang L, Ji W, Zhang Z, Jin X. Thermal conductivity enhancement of water by adding graphene Nano-sheets: consideration of particle loading and temperature effects. Int Commun Heat Mass Transf. 2019;109:104353. https://doi.org/10.1016/j.ichea tmasstransfer.2019.104353.

169. Yang L, Mao M, Huang JN, Ji W. Enhancing the thermal conductivity of SAE 50 engine oil by adding zinc oxide nano-powder: an experimental study. Powder Technol. 2019;356:335-41. https ://doi.org/10.1016/j.powtec.2019.08.031.

170. Mahian $\mathrm{O}$, et al. Recent advances in modeling and simulation of nanofluid flows-part I: fundamentals and theory. Phys Rep. 2019;790:1-48. https://doi.org/10.1016/j.physrep.2018.11.004.

171. Jang SP, Choi SUS. Effects of various parameters on nanofluid thermal conductivity. J Heat Transfer. 2013;129(5):617-23. https ://doi.org/10.1115/1.2712475.

172. Keblinski P, Phillpot SR, Choi SUS, Eastman JA. Mechanism of heat flow in suspensions of nano-sized particles (nanofluids). Int J Heat Mass Transf. 2002;45:855-63.

173. Yu W, Choi SUS. The role of interfacial layers in the enhanced thermal conductivity of nanofluids: a renovated Maxwell model. J Nanoparticle Res. 2003;5:167-71.

174. Xie H, Fujii M, Zhang X. Effect of interfacial nanolayer on the effective thermal conductivity of nanoparticle-fluid mixture. Int J Heat Mass Transf. 2005;48:2926-32. https://doi.org/10.1016/j. ijheatmasstransfer.2004.10.040.

175. Pinto RV, Augusto F, Fiorelli S. Review of the mechanisms responsible for heat transfer enhancement using nanofluids. Appl Therm Eng. 2016;108:720-39. https://doi.org/10.1016/j. applthermaleng.2016.07.147.

176. Khalid M, Rahman S, Ong SS, Saidur R. Preparation, thermophysical properties and heat transfer enhancement of nanofluids. Mater Res Express. 2014;1(3):032001. https://doi. org/10.1088/2053-1591/1/3/032001.

177. Chandrasekar M, Suresh S. A review on the mechanisms of heat transport in nanofluids. Heat Transf Eng. 2011;30(14):1136-50. https://doi.org/10.1080/01457630902972744.

178. Wong KV, Castillo MJ. Heat transfer mechanisms and clustering in nanofluids. Adv Mech Eng. 2010. https://doi. org/10.1155/2010/795478.

179. Wang GCJJ, Zheng RT, Gao JW. Heat conduction mechanisms in nanofluids and suspensions. Nano Today. 2012;7:124-36.

180. Choudhary S, Sachdeva A, Kumar P. Investigation of the stability of $\mathrm{MgO}$ nanofluid and its effect on the thermal performance of flat plate solar collector. Renew Energy. 2020;147:1801-14. https ://doi.org/10.1016/j.renene.2019.09.126.

181. Ahmadlouydarab M, Ebadolahzadeh M, Ali HM. Effects of utilizing nanofluid as working fluid in a lab-scale designed FPSC to improve thermal absorption and efficiency. Phys A Stat Mech Appl. 2020;540:123109. https://doi.org/10.1016/j.physa .2019.123109.

182. Saffarian MR, Moravej M, Doranehgard MH. Heat transfer enhancement in a flat plate solar collector with different flow path shapes using nanofluid. Renew Energy. 2020;146:2316-29. https://doi.org/10.1016/j.renene.2019.08.081.
183. Tong Y, Lee H, Kang W, Cho H. Energy and exergy comparison of a flat-plate solar collector using water, $\mathrm{Al}_{2} \mathrm{O}_{3}$ nanofluid, and CuO nanofluid. Appl Therm Eng. 2019;159:113959. https://doi. org/10.1016/j.applthermaleng.2019.113959.

184. Mondragon R, Sanchez D, Cabello R, Llopis R, Julia E. Flat plate solar collector performance using alumina nanofluids: experimental characterization and efficiency tests. PLoS ONE. 2019;14(2):e0212260.

185. Sarafraz MM, Tlili I, Baseer MA, Safaei MR. Potential of solar collectors for clean thermal energy production in smart cities using nanofluids: experimental assessment and efficiency improvement. Appl Sci. 2019;9(9):1877. https://doi.org/10.3390/ app9091877.

186. Natividade PSG, De Moura GM, Avallone E, Filho EPB, Gelamo RV, De Gonçalves JCSI. Experimental analysis applied to an evacuated tube solar collector equipped with parabolic concentrator using multilayer graphene-based nanofluids. Renew Energy. 2019;138:152-60. https://doi.org/10.1016/j.renene.2019.01.091.

187. Sadeghi G, Nazari S, Ameri M, Shama F. Energy and exergy evaluation of the evacuated tube solar collector using $\mathrm{Cu}_{2} \mathrm{O}$ / water nanofluid utilizing ANN methods. Sustain Energy Technol Assess. 2020;37:100578. https://doi.org/10.1016/j. seta.2019.100578.

188. Korres D, Bellos E, Tzivanidis C. Investigation of a nanofluidbased compound parabolic trough solar collector under laminar flow conditions. Appl Therm Eng. 2019;149:366-76. https://doi. org/10.1016/j.applthermaleng.2018.12.077.

189. Kalogirou SA. Solar energy engineering: processes and systems. 2nd ed. Springer: Berlin; 2014.

190. Ghodbane M, Said Z, Hachicha AA, Boumeddane B. Performance assessment of linear Fresnel solar reflector using MWCNTs/DW nanofluids. Renew Energy. 2019. https://doi. org/10.1016/j.renene.2019.10.137.

191. Okonkwo EC, Essien EA, Kavaz D, Abid M, Ratlamwala TAH. Olive leaf synthesized nanofluids for solar parabolic trough collector-thermal performance evaluation. J Therm Sci Eng Appl. 2019;11(4):041009. https://doi.org/10.1115/1.4043820.

192. Ehyaei MA, Ahmadi A, Assad MEH, Hachicha AA, Said Z. Energy, exergy and economic analyses for the selection of working fluid and metal oxide nanofluids in a parabolic trough collector. Sol Energy. 2019;187:175-84. https://doi.org/10.1016/j. solener.2019.05.046.

193. Malekan M, Khosravi A, Syri S. Heat transfer modeling of a parabolic trough solar collector with working fluid of $\mathrm{Fe}_{3} \mathrm{O}_{4}$ and $\mathrm{CuO} /$ Therminol 66 nanofluids under magnetic field. Appl Therm Eng. 2019;163:114435. https://doi.org/10.1016/j.appltherma leng.2019.114435.

194. Bellos E, Tzivanidis C. Thermal efficiency enhancement of nanofluid-based parabolic trough collectors. J Therm Anal Calorim. 2019;135(1):597-608. https://doi.org/10.1007/s1097 3-018-7056-7.

195. Qin C, Kim JB, Lee BJ. Performance analysis of a direct-absorption parabolic-trough solar collector using plasmonic nanofluids. Renew Energy. 2019;143:24-33. https://doi.org/10.1016/j.renen e.2019.04.146.

196. Tafarroj MM, Daneshazarian R, Kasaeian A. CFD modeling and predicting the performance of direct absorption of nanofluids in trough collector. Appl Therm Eng. 2019;148:256-69. https://doi. org/10.1016/j.applthermaleng.2018.11.020.

197. Simonetti M, Restagno F, Sani E, Noussan M. Numerical investigation of direct absorption solar collectors (DASC), based on carbon-nanohorn nanofluids, for low temperature applications. Sol Energy. 2020;195:166-75. https://doi.org/10.1016/j.solen er.2019.11.044.

198. Sangeetha M, Manigandan S, Chaichan MT, Kumar V. Progress of MWCNT, $\mathrm{Al}_{2} \mathrm{O}_{3}$, and $\mathrm{CuO}$ with water in enhancing the 
photovoltaic thermal system. Int J Energy Res. 2019. https://doi. org/10.1002/er.4905.

199. Alous S, Kayfeci M, Uysal A. Experimental investigations of using MWCNTs and graphene nanoplatelets water-based nanofluids as coolants in PVT systems. Appl Therm Eng. 2019;162:114265. https://doi.org/10.1016/j.appltherma leng.2019.114265.

200. Fudholi A, et al. $\mathrm{TiO}_{2} /$ water-based photovoltaic thermal (PVT) collector: novel theoretical approach. Energy. 2019;183:305-14. https://doi.org/10.1016/j.energy.2019.06.143.

201. Abdelrazik AS, Al-Sulaiman FA, Saidur R, Ben-Mansour R. Evaluation of the effects of optical filtration and nanoPCM on the performance of a hybrid photovoltaic-thermal solar collector. Energy Convers Manag. 2019;195:139-56. https://doi. org/10.1016/j.enconman.2019.04.083.

202. AL-Musawi AIA, Taheri A, Farzanehnia A, Sardarabadi M, Passandideh-Fard M. Numerical study of the effects of nanofluids and phase-change materials in photovoltaic thermal (PVT) systems. J Therm Anal Calorim. 2019;137(2):623-36. https:// doi.org/10.1007/s10973-018-7972-6.

203. Gulzar O, Qayoum A, Gupta R. Photo-thermal characteristics of hybrid nanofluids based on Therminol-55 oil for concentrating solar collectors. Appl Nanosci. 2019;9(5):1133-43. https://doi. org/10.1007/s13204-018-0738-4.

204. Qu J, Zhang R, Wang Z, Wang Q. Photo-thermal conversion properties of hybrid $\mathrm{CuO}-\mathrm{MWCNT} / \mathrm{H}_{2} \mathrm{O}$ nanofluids for direct solar thermal energy harvest. Appl Therm Eng. 2019;147:390-8. https://doi.org/10.1016/j.applthermaleng.2018.10.094.

205. Hazra SK, Ghosh S, Nandi TK. Photo-thermal conversion characteristics of carbon black-ethylene glycol nanofluids for applications in direct absorption solar collectors. Appl Therm Eng. 2019. https://doi.org/10.1016/j.applthermaleng.2019.114402.

206. Motamedi M, et al. Experimental testing of hydrophobic microchannels, with and without nanofluids, for solar PV/T collectors. Energies. 2019. https://doi.org/10.3390/en12153036.

207. Du Q, Xu J, Cheng Z, Gao J. Experimental study on sunlight absorption characteristics of Au-CuS blended nanofluids. Energy Sources Part A Recover Util Environ Eff. 2019. https://doi. org/10.1080/15567036.2019.1576078.

208. Wang D, et al. Enhanced photothermal conversion properties of magnetic nanofluids through rotating magnetic field for direct absorption solar collector. J Colloid Interface Sci. 2019;557:26675. https://doi.org/10.1016/j.jcis.2019.09.022.

209. Wang K, et al. Significant photothermal conversion enhancement of nanofluids induced by Rayleigh-Bénard convection for direct absorption solar collectors. Appl Energy. 2019;254:20. https:// doi.org/10.1016/j.apenergy.2019.113706.

210. Sharaf OZ, et al. Ultrastable plasmonic nanofluids in optimized direct absorption solar collectors. Energy Convers Manag. 2019;199:112010. https://doi.org/10.1016/j.encon man.2019.112010.

211. Liu C, Wang D, He Y, Wang K, Yu W. Properties of solar energy absorption and photothermal conversion at medium temperature based on magnetic nanofluids. Kexue Tongbao/Chinese Sci Bull. 2019;64(28-29):3041-8. https://doi.org/10.1360/TB-2019-0186.

212. Vallejo JP, et al. Comparative study of different functionalized graphene-nanoplatelet aqueous nanofluids for solar energy applications. Renew Energy. 2019;141:791-801. https://doi. org/10.1016/j.renene.2019.04.075.

213. Sami S. Impact of magnetic field on the enhancement of performance of thermal solar collectors using nanofluids. Int J Ambient Energy. 2019;40(8):875-84. https://doi.org/10.1080/01430 750.2018.1437561

214. Farshad SA, Sheikholeslami M. Nanofluid flow inside a solar collector utilizing twisted tape considering exergy and entropy analysis. Renew Energy. 2019;141:246-58. https://doi. org/10.1016/j.renene.2019.04.007.

215. Delfani S, Esmaeili M, Karami M. Application of artificial neural network for performance prediction of a nanofluid-based direct absorption solar collector. Sustain Energy Technol Assess. 2019;36:100559. https://doi.org/10.1016/j.seta.2019.100559.

216. Sadeghzadeh M, Ahmadi MH, Kahani M, Sakhaeinia H, Chaji $\mathrm{H}$, Chen L. Smart modeling by using artificial intelligent techniques on thermal performance of flat-plate solar collector using nanofluid. Energy Sci Eng. 2019;7(5):1649-58. https://doi. org/10.1002/ese 3.381.

217. Okonkwo EC, Adun H, Babatunde AA, Abid M, Ratlamwala TAH. Entropy generation minimization in a parabolic trough collector operating with $\mathrm{SiO}_{2}$ - water nanofluids using genetic algorithm and artificial neural network. J Therm Sci Eng Appl. 2020;12(3):031007. https://doi.org/10.1115/1.4044755.

218. Sharafeldin MA, Gróf G. Efficiency of evacuated tube solar collector using WO3/Water nanofluid. Renew Energy. 2019;134:453-60. https://doi.org/10.1016/j.renene.2018.11.010.

219. Peng $\mathrm{Y}$, et al. Investigation of energy performance in a U-shaped evacuated solar tube collector using oxide added nanoparticles through the emitter, absorber and transmittal environments via discrete ordinates radiation method. J Therm Anal Calorim. 2019. https://doi.org/10.1007/s10973-019-08684-w.

220. Kaya H, Arslan K. Numerical investigation of efficiency and economic analysis of an evacuated U-tube solar collector with different nanofluids. Heat Mass Transf Stoffuebertragung. 2019;55(3):581-93. https://doi.org/10.1007/s00231-018-2442-z.

221. Kang W, Shin Y, Cho H. Experimental investigation on the heat transfer performance of evacuated tube solar collector using $\mathrm{CuO}$ nanofluid and water. J Mech Sci Technol. 2019;33(3):1477-85. https://doi.org/10.1007/s12206-019-0249-6.

222. Sharafeldin MA, Gróf G, Abu-Nada E, Mahian O. Evacuated tube solar collector performance using copper nanofluid: energy and environmental analysis. Appl Therm Eng. 2019;162:114205. https://doi.org/10.1016/j.applthermaleng.2019.114205.

223. Sarafraz MM, Safaei MR. Diurnal thermal evaluation of an evacuated tube solar collector (ETSC) charged with graphene nanoplatelets-methanol nano-suspension. Renew Energy. 2019;142:364-72. https://doi.org/10.1016/j.renene.2019.04.091.

224. Mercan M, Yurddaş A. Numerical analysis of evacuated tube solar collectors using nanofluids. Sol Energy. 2019;191:167-79. https://doi.org/10.1016/j.solener.2019.08.074.

225. Sadeghi G, Safarzadeh H, Ameri M. Experimental and numerical investigations on performance of evacuated tube solar collectors with parabolic concentrator, applying synthesized $\mathrm{Cu}_{2} \mathrm{O}$ /distilled water nanofluid. Energy Sustain Dev. 2019;48:88-106. https:// doi.org/10.1016/j.esd.2018.10.008.

226. Bellos E, Tzivanidis C, Papadopoulos A. Enhancing the performance of a linear Fresnel reflector using nanofluids and internal finned absorber. J Therm Anal Calorim. 2019;135(1):237-55. https://doi.org/10.1007/s10973-018-6989-1.

227. Arora S, Fekadu G, Subudhi S. Energy and exergy analysis of marquise shaped channel flat plate solar collector using $\mathrm{Al}_{2} \mathrm{O}_{3}$-water nanofluid and water. J Sol Energy Eng Trans ASME. 2019. https://doi.org/10.1115/1.4042454.

228. Sacithra A, Manivannan A. Turbulent flow analysis of a flattened tube in- plane curved solar collector using Titanium oxide nanofluid. Heat Mass Transf Stoffuebertragung. 2019;55(6):1783-99. https://doi.org/10.1007/s00231-018-02557-y.

229. Farhana K, Kadirgama K, Noor MM, Rahman MM, Ramasamy D, Mahamude ASF. CFD modelling of different properties of nanofluids in header and riser tube of flat plate solar collector. In: IOP Conference Series: Materials Science and Engineering; 2019. https://doi.org/10.1088/1757-899x/469/1/012041. 
230. Stalin PMJ, Arjunan TV, Matheswaran MM, Sadanandam N. Experimental and theoretical investigation on the effects of lower concentration $\mathrm{CeO}_{2}$ /water nanofluid in flat-plate solar collector. J Therm Anal Calorim. 2019;135(1):29-44. https://doi. org/10.1007/s10973-017-6865-4.

231. Kabeel AE, El-Agouz ES, Prakash N, Prasad C, Sathyamurthy R, Manokar AM. Performance analysis of spiral and serpentine tube solar collector with carbon nanotube nanofluids under natural flow method. Heat Transf Asian Res. 2019;48(6):2428-39. https ://doi.org/10.1002/htj.21502.

232. Hajabdollahi Z, Hajabdollahi H, Kim KC. Multi-objective optimization of solar collector using water-based nanofluids with different types of nanoparticles. J Therm Anal Calorim. 2019. https://doi.org/10.1007/s10973-019-08444-w.

233. Hajabdollahi Z, Mirzaei M, Kim KC. Effects of a mixture of cuo and al2o3 nanoparticles on the thermal efficiency of a flat plate solar collector at different mass flow rates. Heat Transf Res. 2019;50(10):945-65. https://doi.org/10.1615/HeatTransR es. 2018027822.

234. Stalin PMJ, Arjunan TV, Matheswaran MM, Dolli H, Sadanandam N. Energy, economic and environmental investigation of a flat plate solar collector with $\mathrm{CeO}_{2}$ /water nanofluid. J Therm Anal Calorim. 2019. https://doi.org/10.1007/s10973-019-08670 -2 .

235. Mirzaei M. Experimental investigation of $\mathrm{CuO}$ nanofluid in the thermal characteristics of a flat plate solar collector. Environ Prog Sustain Energy. 2019;38(1):260-7. https://doi.org/10.1002/ ep. 12902.

236. Eltaweel M, Abdel-Rehim AA. Energy and exergy analysis of a thermosiphon and forced-circulation flat-plate solar collector using MWCNT/Water nanofluid. Case Stud Therm Eng. 2019;14:100416. https://doi.org/10.1016/j.csite.2019.100416.

237. Akram N, et al. An experimental investigation on the performance of a flat-plate solar collector using eco-friendly treated graphene nanoplatelets-water nanofluids. J Therm Anal Calorim. 2019;138(1):609-21. https://doi.org/10.1007/s10973-019-08153 -4 .

238. Alawi OA, Kamar HM, Mallah AR, Kazi SN, Sidik NAC. Thermal efficiency of a flat-plate solar collector filled with Pentaethylene Glycol-Treated Graphene Nanoplatelets: an experimental analysis. Sol Energy. 2019;191:360-70. https://doi.org/10.1016/j. solener.2019.09.011.

239. Jouybari HJ, Nimvari ME, Saedodin S. Thermal performance evaluation of a nanofluid-based flat-plate solar collector: an experimental study and analytical modeling. J Therm Anal Calorim. 2019;137(5):1757-74. https://doi.org/10.1007/s1097 3-019-08077-z.

240. Asgharian H, Baniasadi E, Colpan CO. Energy, exergy and exergoeconomic analyses of a solar refrigeration cycle using nanofluid. Int J Exergy. 2019;30(1):63-85. https://doi. org/10.1504/IJEX.2019.101625.

241. Okonkwo EC, Wole-osho I, Kavaz D, Abid M, Al-ansari T. Thermodynamic evaluation and optimization of a flat plate collector operating with alumina and iron mono and hybrid nanofluids. Sustain Energy Technol Assess. 2020;37:100636. https://doi.org/10.1016/j.seta.2020.100636.

242. Dehaj MS, Mohiabadi MZ. Experimental study of water-based $\mathrm{CuO}$ nanofluid flow in heat pipe solar collector. J Therm Anal Calorim. 2019;137(6):2061-72. https://doi.org/10.1007/s1097 3-019-08046-6.

243. Shafieian A, Osman JJ, Khiadani M, Nosrati A. Enhancing heat pipe solar water heating systems performance using a novel variable mass flow rate technique and different solar working fluids. Sol Energy. 2019;186:191-203. https://doi. org/10.1016/j.solener.2019.05.016.
244. Karami M. Experimental investigation of first and second laws in a direct absorption solar collector using hybrid $\mathrm{Fe}_{3} \mathrm{O}_{4} / \mathrm{SiO}_{2}$ nanofluid. J Therm Anal Calorim. 2019;136(2):661-71. https ://doi.org/10.1007/s10973-018-7624-x.

245. Alsaady M, Fu R, Yan Y, Liu Z, Wu S, Boukhanouf R. An experimental investigation on the effect of ferrofluids on the efficiency of novel parabolic trough solar collector under laminar flow conditions. Heat Transf Eng. 2019;40(9/10):753-61. https://doi.org/10.1080/01457632.2018.1442309.

246. Okonkwo EC, Abid M, Ratlamwala TAH, Abbasoglu S, Dagbasi M. Optimal analysis of entropy generation and heat transfer in parabolic trough collector using green-synthesized $\mathrm{TiO}_{2} /$ water nanofluids. J Sol Energy Eng. 2019;141(3):031011.

247. Tayebi R, Akbarzadeh S, Valipour MS. Numerical investigation of efficiency enhancement in a direct absorption parabolic trough collector occupied by a porous medium and saturated by a nanofluid. Environ. Prog. Sustain. Energy. 2019;38(2):72740. https://doi.org/10.1002/ep.13010.

248. Razmmand F, Mehdipour R, Mousavi SM. A numerical investigation on the effect of nanofluids on heat transfer of the solar parabolic trough collectors. Appl Therm Eng. 2019;152:62433. https://doi.org/10.1016/j.applthermaleng.2019.02.118.

249. Al-Oran O, Lezsovits F, Aljawabrah A. Exergy and energy amelioration for parabolic trough collector using mono and hybrid nanofluids. J Therm Anal Calorim. 2020. https://doi. org/10.1007/s10973-020-09371-x.

250. Fathabadi H. Novel solar collector: evaluating the impact of nanoparticles added to the collector's working fluid, heat transfer fluid temperature and flow rate. Renew Energy. 2019. https ://doi.org/10.1016/j.renene.2019.10.008.

251. Kasaeian A, Daneshazarian R, Pourfayaz F, Babaei S, Sheikhpour M, Nakhjavani S. Evaluation of MWCNT/ethylene glycol nanofluid flow in a parabolic trough collector with glass-glass absorber tube. Int J Numer Methods Heat Fluid Flow. 2019. https://doi.org/10.1108/hff-11-2018-0693.

252. Hadi AI, Jamel MS. Effect of the design and environment parameters on the thermal efficiency and heat losses of a parabolic trough solar collector using nanofluid technology. Int J Mech Eng Technol. 2019;10(1):571-93.

253. Kumar D, Kumari S. Performance investigation of a nanofluidbased parabolic trough solar collector. In: Kumar M, Pandey R, Kumar V, editors. Advances in interdisciplinary engineering, vol. 1., Lecture Notes in Mechanical EngineeringSingapore: Springer; 2019.

254. Islam MK, Hasanuzzaman M, Rahim NA, Nahar A. Effect of nanofluid properties and mass flow rate on heat transfer of on heat transfer of parabolic trough concentrating solar system. J Nav Archit Mar Eng. 2019;16(1):33-44. https://doi. org/10.3329/jname.v16i1.30548.

255. Norouzi AM, Siavashi M, Oskouei MHK. Efficiency enhancement of the parabolic trough solar collector using the rotating absorber tube and nanoparticles. Renew Energy. 2020;145:56984. https://doi.org/10.1016/j.renene.2019.06.027.

256. Bozorg MV, Doranehgard MH, Hong K, Xiong Q. CFD study of heat transfer and fluid flow in a parabolic trough solar receiver with internal annular porous structure and synthetic oil- $\mathrm{Al}_{2} \mathrm{O}_{3}$ nanofluid. Renew Energy. 2020;145:2598-614. https://doi. org/10.1016/j.renene.2019.08.042.

257. Quezada-García S, Sánchez-Mora H, Polo-Labarrios MA, Cázares-Ramírez RI. Modeling and simulation to determine the thermal efficiency of a parabolic solar trough collector system. Case Stud Therm Eng. 2019;16:100523. https://doi.org/10.1016/j.csite .2019.100523.

258. Campos CS, Torres JPN, Fernandes JFP. Effects of the heat transfer fluid selection on the efficiency of a hybrid concentrated 
photovoltaic and thermal collector. Energies. 2019;12(9):1-12. https://doi.org/10.3390/en12091814.

259. Gangadevi R, Vinayagam BK. Experimental determination of thermal conductivity and viscosity of different nanofluids and its effect on a hybrid solar collector. J Therm Anal Calorim. 2019;136(1):199-209. https://doi.org/10.1007/s1097 3-018-7840-4.

260. Ahmed OK, Bawa SM. The combined effect of nanofluid and reflective mirrors on the performance of $\mathrm{PV} /$ Thermal solar collector. Therm Sci. 2019;23(2):573-87. https://doi.org/10.2298/ TSCI171203092A.

261. Qi C, Luo T, Liu M, Fan F, Yan Y. Experimental study on the flow and heat transfer characteristics of nanofluids in double-tube heat exchangers based on thermal efficiency assessment. Energy Convers Manag. 2019;197:111877. https://doi.org/10.1016/j. enconman.2019.111877.

262. Moradi A, Toghraie D, Isfahani AHM, Hosseinian A. An experimental study on MWCNT-water nanofluids flow and heat transfer in double-pipe heat exchanger using porous media. J Therm Anal Calorim. 2019;137(5):1797-807. https://doi.org/10.1007/ s10973-019-08076-0.

263. Mohankumar T, Rajan K, Sivakumar K, Gopal V. Experimental analysis of heat transfer characteristics of heat exchanger using nano fluids. IOP Conf Ser Mater Sci Eng. 2019;574(1):45-69. https://doi.org/10.1088/1757-899x/574/1/012011.

264. Mehta KS, Kundan L, Mallick SS. A study on heat transfer and pressure drop in a turbulent flow regime of thermally insulated and conducting nanofluids. J Nanofluids. 2019;8(3):490-9. https ://doi.org/10.1166/jon.2019.1602.

265. Zheng M, Han D, Asif F, Si Z. Effect of $\mathrm{Al}_{2} \mathrm{O}_{3}$ /water nanofluid on heat transfer of turbulent flow in the inner pipe of a double-pipe heat exchanger. Heat Mass Transf Stoffuebertragung. 2019. https ://doi.org/10.1007/s00231-019-02774-z.

266. Returi MC, Konijeti R, Dasore A. Heat transfer enhancement using hybrid nanofluids in spiral plate heat exchangers. Heat Transf Res. 2019;48(7):3128-43. https://doi.org/10.1002/ htj. 21534

267. Kayabaşı U, Kakaç S, Aradag S, Pramuanjaroenkij A. Experimental investigation of thermal and hydraulic performance of a plate heat exchanger using nanofluids. J Eng Phys Thermophys. 2019;92(3):783-96. https://doi.org/10.1007/s10891-019-01987 $-7$.

268. Variyenli HI. Experimental and numerical investigation of heat transfer enhancement in a plate heat exchanger using a fly ash nanofluid. Heat Transf Res. 2019;50(15):1477-94. https://doi. org/10.1615/HeatTransRes.2019029136.

269. Meisam A, Ahmad A, Hamed M. Experimental investigation of metal oxide nanofluids in a plate heat exchanger. $\mathrm{J}$ Thermophys Heat Transf. 2019;33(4):994-1005. https://doi.org/10.2514/1. T5581.

270. Teng TP, Hsiao TC, Chung CC. Characteristics of carbon-based nanofluids and their application in a brazed plate heat exchanger under laminar flow. Appl Therm Eng. 2019;146:160-8. https:// doi.org/10.1016/j.applthermaleng.2018.09.125.

271. Hosseini SM, Safaei MR, Estellé P, Jafarnia SH. Heat transfer of water-based carbon nanotube nanofluids in the shell and tube cooling heat exchangers of the gasoline product of the residue fluid catalytic cracking unit. J Therm Anal Calorim. 2019;56:2019. https://doi.org/10.1007/s10973-019-08813-5.

272. Naik BAK, Vinod AV. Energy savings and effectiveness in a compact heat exchanger employing non-newtonian nanofluids. J Nanofluids. 2019;8(7):1535-43. https://doi.org/10.1166/ jon.2019.1700.

273. Permanasari AA, Kuncara BS, Puspitasari P, Sukarni S, Ginta TL, Irdianto W. Convective heat transfer characteristics of
$\mathrm{TiO}_{2}$-EG nanofluid as coolant fluid in heat exchanger. AIP Conf Proc. 2019;2120:56. https://doi.org/10.1063/1.5115691.

274. Said Z, Rahman SMA, El Assad MH, Alami AH. Heat transfer enhancement and life cycle analysis of a Shell-and-Tube Heat Exchanger using stable $\mathrm{CuO} /$ water nanofluid. Sustain Energy Technol Assess. 2019;31:306-17. https://doi.org/10.1016/j. seta.2018.12.020.

275. Ullah MR, Ishtiaq TM, Mamun MAH. Heat transfer enhancement in shell and tube heat exchanger by using $\mathrm{Al}_{2} \mathrm{O}_{3}$ /water and $\mathrm{TiO}_{2}$ /water nanofluid. AIP Conf Proc. 2019;2121:2019. https:// doi.org/10.1063/1.5115925.

276. Khanlari A, Sözen A, Variyenli HI, Gürü M. Comparison between heat transfer characteristics of $\mathrm{TiO}_{2} /$ deionized water and kaolin/deionized water nanofluids in the plate heat exchanger. Heat Transf Res. 2019;50(5):435-50. https://doi.org/10.1615/ heattransres.2018026288.

277. Ali AYM, El-Shazly AH, El-Kady MF, Elqady HI, El-Marghany MR. Effect of using MgO-oil nanofluid on the performance of a counter-flow double pipe heat exchanger. Key Eng Mater. 2019;801:193-8. https://doi.org/10.4028/www.scientific.net/ KEM.801.193.

278. Kumar V, Pandya N, Pandya B, Joshi A. Synthesis of metal-based nanofluids and their thermo-hydraulic performance in compact heat exchanger with multi-louvered fins working under laminar conditions. J Therm Anal Calorim. 2019;135(4):2221-35. https ://doi.org/10.1007/s10973-018-7304-x.

279. Suroso B, Kamal S, Kristiawan B, Irawansyah H, Wibowo BS, Yani M. Convective heat transfer of nanofluids $\mathrm{TiO}_{2} /$ Thermo Oil XT 32 in concentric tube heat exchanger. IOP Conf Ser Mater Sci Eng. 2019. https://doi.org/10.1088/1757-899x/674/1/012063.

280. Subramanian R, Kumar AS, Vinayagar K, Muthusamy C. Experimental analyses on heat transfer performance of $\mathrm{TiO}_{2}-$ water nanofluid in double-pipe counter-flow heat exchanger for various flow regimes. J Therm Anal Calorim. 2019. https://doi. org/10.1007/s10973-019-08887-1.

281. Monfared M, Shahsavar A, Bahrebar MR. Second law analysis of turbulent convection flow of boehmite alumina nanofluid inside a double-pipe heat exchanger considering various shapes for nanoparticle. J Therm Anal Calorim. 2019;135(2):1521-32. https://doi.org/10.1007/s10973-018-7708-7.

282. Shirzad M, Ajarostaghi SSM, Delavar MA, Sedighi K. Improve the thermal performance of the pillow plate heat exchanger by using nanofluid: numerical simulation. Adv Powder Technol. 2019;30(7):1356-65. https://doi.org/10.1016/j.apt.2019.04.011.

283. Kumar SD, Purushothaman K. Enhancement of thermal conductivity in a plate heat exchanger by using nanoparticles CNT, $\mathrm{Al}_{2} \mathrm{O}_{3}$, surfactant with de-ionised water as a coolant. Int J Ambient Energy. 2019. https://doi.org/10.1080/01430750.2018.15629 79.

284. Koshta NR, Bhanvase BA, Chawhan SS, Barai DP, Sonawane SH. Investigation on the thermal conductivity and convective heat transfer enhancement in helical coiled heat exchanger using ultrasonically prepared $\mathrm{rGO}-\mathrm{TiO}_{2}$ nanocomposite-based nanofluids. Indian Chem Eng. 2019. https://doi. org/10.1080/00194506.2019.1658545.

285. Solangi KH, Sharif S, Nizamani B. Effect of tube material on convective heat transfer of various nanofluids. J Therm Anal Calorim. 2019. https://doi.org/10.1007/s10973-019-08835-z.

286. Nikkhah V, Nakhjavani S. Thermal performance of a micro heat exchanger (MHE) working with zirconia-based nanofluids for industrial cooling. Int J Ind Chem. 2019;10(2):193-204. https://doi.org/10.1007/s40090-019-0183-6.

287. Sözen A, Khanları A, Çiftçi E. Heat transfer enhancement of plate heat exchanger utilizing kaolin-including working fluid. Proc Inst Mech Eng Part A J Power Energy. 2019;233(5):62634. https://doi.org/10.1177/0957650919832445. 
288. Gustavo J, Fnu A, Valentin S, Mosfequr R. Erosion-corrosion wear of heat-exchanger materials by water/ethylene-glycol/ alumina nanofluids. Int J Surf Eng Interdiscip Mater Sci. 2018;6(2):1-22.

289. Ramalingam S, Dhairiyasamy R, Govindasamy M. Consequence of nanoparticle physiognomies on heat transfer characteristics of heat exchanger. Energy Sources Part A Recover Util Environ Eff. 2019. https://doi.org/10.1080/15567 036.2019.1670759.

290. Tian Z, et al. Turbulent flows in a spiral double-pipe heat exchanger: optimal performance conditions using an enhanced genetic algorithm. Int J Numer Methods Heat Fluid Flow. 2019. https://doi.org/10.1108/hff-04-2019-0287.

291. Shahsavar A, Rahimi Z, Salehipour H. Nanoparticle shape effects on thermal-hydraulic performance of boehmite alumina nanofluid in a horizontal double-pipe minichannel heat exchanger. Heat Mass Transf Stoffuebertragung. 2019;55(6):1741-51. https ://doi.org/10.1007/s00231-018-02558-x.

292. Khanlari A, Sözen A, Variyenli Hİ. Simulation and experimental analysis of heat transfer characteristics in the plate type heat exchangers using $\mathrm{TiO}_{2}$ /water nanofluid. Int J Numer Methods Heat Fluid Flow. 2019;29(4):1343-62. https://doi.org/10.1108/ HFF-05-2018-0191.

293. Osman S, Sharifpur M, Meyer JP. Experimental investigation of convection heat transfer in the transition flow regime of aluminium oxide-water nanofluids in a rectangular channel. Int $\mathbf{J}$ Heat Mass Transf. 2019;133:895-902. https://doi.org/10.1016/j. ijheatmasstransfer.2018.12.169.

294. Bhattad A, Sarkar J, Ghosh P. Experimentation on effect of particle ratio on hydrothermal performance of plate heat exchanger using hybrid nanofluid. Appl Therm Eng. 2019;162:114309. https://doi.org/10.1016/j.applthermaleng.2019.114309.

295. Bhattad A, Sarkar J, Ghosh P. Hydrothermal performance of different alumina hybrid nanofluid types in plate heat exchanger: experimental study. J Therm Anal Calorim. 2019. https://doi. org/10.1007/s10973-019-08682-y.

296. Ozdemir MB, Ergun ME. Experimental and numerical investigations of thermal performance of $\mathrm{Al}_{2} \mathrm{O}_{3}$ /water nanofluid for a combi boiler with double heat exchangers. Int J Numer Methods Heat Fluid Flow. 2019;29(4):1300-21. https://doi.org/10.1108/ HFF-05-2018-0189.

297. Talari VK, Thamida SK, Sastry RC. Determination of optimum concentration of nanofluid for process intensification of heat transfer using corrugated plate type heat exchanger. Chem Prod Process Model. 2019;14(1):2019. https://doi.org/10.1515/ cppm-2018-0002.

298. Arulprakasajothi M, Raja ND, Beemkumar N, Elangovan $\mathrm{K}$. Experimental study on $\mathrm{Al}_{2} \mathrm{O}_{3} / \mathrm{H}_{2} \mathrm{O}$ nanofluid with conical sectional insert in concentric tube heat exchanger. Energy Sources Part A Recover Util Environ Eff. 2019. https://doi. org/10.1080/15567036.2019.1649753.

299. Mansoury D, Doshmanziari FI, Rezaie S, Rashidi MM. Effect of $\mathrm{Al}_{2} \mathrm{O}_{3}$ /water nanofluid on performance of parallel flow heat exchangers: an experimental approach. J Therm Anal Calorim. 2019;135(1):625-43. https://doi.org/10.1007/s1097 3-018-7286-8.

300. Kong R, Deethayat T, Asanakham A, Kiatsiriroat T. Thermal characteristics of helical coiled heat exchanger with graphenedeionized water on waste heat recovery of combustion stack gas. Chiang Mai Univ J Nat Sci. 2019;18(1):50-67. https://doi. org/10.12982/CMUJNS.2019.0005.

301. Liu WI, Al-Rashed AAAA, Alsagri AS, Mahmoudi B, Shahsavar A, Afrand M. Laminar forced convection performance of non-Newtonian water-CNT/ $/ \mathrm{Fe}_{3} \mathrm{O}_{4}$ nano-fluid inside a minichannel hairpin heat exchanger: effect of inlet temperature. Powder
Technol. 2019;354:247-58. https://doi.org/10.1016/j.powte c.2019.05.079.

302. Toghraie D, Hekmatifar M, Jolfaei NA. Investigation of heat transfer and fluid flow behaviors of $\mathrm{CuO} /(60: 40) \%$ ethylene gly$\mathrm{col}$ and water nanofluid through a serpentine milichannel heat exchanger; 2019.

303. Soman DP, Karthika S, Kalaichelvi P, Radhakrishnan TK. Experimental study of turbulent forced convection heat transfer and friction factor in dimpled plate heat exchanger. Appl Therm Eng. 2019;162:2019. https://doi.org/10.1016/j.appltherma leng.2019.114254.

304. Mansoury D, Doshmanziari FI, Kiani A, Chamkha AJ, Sharifpur M. Heat transfer and flow characteristics of $\mathrm{Al}_{2} \mathrm{O}_{3}$ /water nanofluid in various heat exchangers: experiments on counter flow. Heat Transf Eng. 2019. https://doi.org/10.1080/01457 632.2018.1528051.

305. Anvari AR, Javaherdeh K, Emami-Meibodi M. Investigation of heat transfer and pressure drop of non-newtonian nanofluid performance through micro channels heat exchanger (MCHE) in cross-flow configuration. J Nanofluids. 2019;8(3):631-9. https ://doi.org/10.1166/jon.2019.1600.

306. Anitha S, Thomas T, Parthiban V, Pichumani M. What dominates heat transfer performance of hybrid nanofluid in single pass shell and tube heat exchanger? Adv Powder Technol. 2019;30(12):3107-17. https://doi.org/10.1016/j.apt.2019.09.018.

307. Sundar LS, Kumar NTR, Addis BM, Bhramara P, Singh MK, Sousa ACM. Heat transfer and effectiveness experimentallybased analysis of wire coil with core-rod inserted in $\mathrm{Fe}_{3} \mathrm{O}_{4} /$ water nanofluid flow in a double pipe U-bend heat exchanger. Int $\mathrm{J}$ Heat Mass Transf. 2019;134:405-19. https://doi.org/10.1016/j.ijhea tmasstransfer.2019.01.041.

308. Attalla M, Maghrabie HM. An experimental study on heat transfer and fluid flow of rough plate heat exchanger using $\mathrm{Al}_{2} \mathrm{O}_{3}$ /water nanofluid. Exp Heat Transf. 2019. https://doi. org/10.1080/08916152.2019.1625469.

309. Mikhailenko SA, Sheremet MA, Pop I. Convective heat transfer in a rotating nanofluid cavity with sinusoidal temperature boundary condition. J Therm Anal Calorim. 2019;137(3):799-809. https://doi.org/10.1007/s10973-018-7984-2.

310. Bondarenko DS, Sheremet MA, Oztop HF, Ali ME. Impacts of moving wall and heat-generating element on heat transfer and entropy generation of $\mathrm{Al}_{2} \mathrm{O}_{3} / \mathrm{H}_{2} \mathrm{O}$ nanofluid. $\mathrm{J}$ Therm Anal Calorim. 2019;136(2):673-86. https://doi.org/10.1007/s1097 3-018-7715-8.

311. Sheremet MA, Pop I. Marangoni natural convection in a cubical cavity filled with a nanofluid: buongiorno's nanofluid model. J Therm Anal Calorim. 2019;135(1):357-69. https://doi. org/10.1007/s10973-018-7069-2.

312. Bondarenko DS, Sheremet MA, Oztop HF, Ali ME. Natural convection of $\mathrm{A} 12 \mathrm{O} 3 / \mathrm{H} 2 \mathrm{O}$ nanofluid in a cavity with a heatgenerating element. Heatline visualization. Int J Heat Mass Transf. 2019;130:564-74. https://doi.org/10.1016/j.ijheatmass transfer.2018.10.091.

313. Mikhailenko SA, Sheremet MA, Oztop HF, Abu-Hamdeh $\mathrm{N}$. Thermal convection in $\mathrm{Al}_{2} \mathrm{O}_{3}$-water nanoliquid rotating chamber with a local isothermal heater. Int $\mathrm{J}$ Mech Sci. 2019;156:137-45. https://doi.org/10.1016/j.ijmec sci.2019.03.037.

314. Dogonchi AS, Sheremet MA, Ganji DD, Pop I. Free convection of copper-water nanofluid in a porous gap between hot rectangular cylinder and cold circular cylinder under the effect of inclined magnetic field. J Therm Anal Calorim. 2019;135(2):1171-84. https://doi.org/10.1007/s10973-018-7396-3.

315. Bondarenko DS, Sheremet MA, Oztop HF, Abu-Hamdeh N. Mixed convection heat transfer of a nanofluid in a lid-driven enclosure with two adherent porous blocks. J Therm Anal 
Calorim. 2019;135(2):1095-105. https://doi.org/10.1007/s1097 3-018-7455-9.

316. Sheremet MA, Pop I, Baytas AC. Non-equilibrium natural convection in a differentially-heated nanofluid cavity partially filled with a porous medium. Int J Numer Methods Heat Fluid Flow. 2019;29(8):2524-44. https://doi.org/10.1108/ HFF-08-2018-0433.

317. Buonomo B, Manca O, Bondareva NS, Sheremet MA. Thermal and fluid dynamic behaviors of confined slot jets impinging on an isothermal moving surface with nanofluids. Energies. 2019. https://doi.org/10.3390/en12112074.

318. Ma Y, Mohebbi R, Rashidi MM, Yang Z, Sheremet MA. Numerical study of MHD nanofluid natural convection in a baffled U-shaped enclosure. Int J Heat Mass Transf. 2019;130:123-34. https://doi.org/10.1016/j.ijheatmasstransfer.2018.10.072.

319. Vishnuprasad S, Haribabu K, Perarasu V. Experimental study on the convective heat transfer performance and pressure drop of functionalized graphene nanofluids in electronics cooling system. Heat Mass Transf. 2019;55(8):2221-34. https://doi.org/10.3795/ KSME-B.2019.43.9.661.

320. Joy RC, Rajan AA, Solomon AB, Ramachandran K, Pillai BC. Experimental investigation on the critical heat flux of $\mathrm{Cu}-$ water, Al-water nanofluids for precise cooling of electronic systems. IOP Conf Ser Mater Sci Eng. 2019;561:1. https://doi. org/10.1088/1757-899x/561/1/012036.

321. Zing C, Mahjoob S, Vafai K. Analysis of porous filled heat exchangers for electronic cooling. Int J Heat Mass Transf. 2019;133:268-76. https://doi.org/10.1016/j.ijheatmasstrans fer.2018.12.067.

322. Bezaatpour M, Goharkhah M. A novel heat sink design for simultaneous heat transfer enhancement and pressure drop reduction utilizing porous fins and magnetite ferrofluid. Int J Numer Methods Heat Fluid Flow. 2019;29(9):3128-47. https://doi. org/10.1108/HFF-12-2018-0810.

323. Al-Rashed A, Shahsavar A, Entezari S, Moghimi MA, Adio SA, Nguyen TK. Numerical investigation of non-Newtonian water$\mathrm{CMC} / \mathrm{CuO}$ nanofluid flow in an offset strip-fin microchannel heat sink: thermal performance and thermodynamic considerations. Appl Therm Eng. 2019;155:247-58. https://doi.org/10.1016/j. applthermaleng.2019.04.009.

324. Qiu L, et al. Coating-boosted interfacial thermal transport for carbon nanotube array nano-thermal interface materials. Carbon N. Y. 2019;145:725-33. https://doi.org/10.1016/j.carbo n.2019.01.085

325. Hong F, Cheng P. Three dimensional numerical analyses and optimization of offset strip-fin microchannel heat sinks. Int Commun Heat Mass Transf. 2009;36:651-6. https://doi.org/10.1016/j. icheatmasstransfer.2009.02.015.

326. Saghir MZ, Welsford C, Thanapathy P, Bayomy AM, Delisle C. Experimental measurements and numerical computation of nano heat transfer enhancement inside a porous material. J Therm Sci Eng Appl. 2020;12:1. https://doi.org/10.1115/1.4041936.

327. Ali M, Shoukat AA, Tariq HA, Anwar M, Ali H. Header design optimization of mini-channel heat sinks using $\mathrm{CuO}-\mathrm{H}_{2} \mathrm{O}$ and $\mathrm{Al}_{2} \mathrm{O}_{3}-\mathrm{H}_{2} \mathrm{O}$ nanofluids for thermal management. Arab J Sci Eng. 2019;44(12):10327-38. https://doi.org/10.1007/s13369-01904022-2.

328. Hadavand M, Yousefzadeh S, Akbari OA, Pourfattah F, Nguyen $\mathrm{HM}$, Asadi A. A numerical investigation on the effects of mixed convection of Ag-water nanofluid inside a sim-circular lid-driven cavity on the temperature of an electronic silicon chip. Appl Therm Eng. 2019;162:114298. https://doi.org/10.1016/j.applt hermaleng.2019.114298.

329. Bahiraei M, Heshmatian S, Goodarzi M, Moayedi H. CFD analysis of employing a novel ecofriendly nanofluid in a miniature pin fin heat sink for cooling of electronic components: effect of different configurations. Adv Powder Technol. 2019;30:2503-16. https://doi.org/10.1016/j.apt.2019.07.029.

330. Fadhil AM, Khalil WH, Al-damook A. The hydraulic-thermal performance of miniature compact heat sinks using $\mathrm{SiO}_{2}$-water nanofluids. Heat Transf Asian Res. 2019;48(7):3101-14. https:// doi.org/10.1002/htj.21532.

331. Riehl RR. Thermal enhancement using nanofluids on high heat dissipation electronic components. J Nanofluids. 2019;8(1):30 40. https://doi.org/10.1166/jon.2019.1563.

332. Ma H, Duan Z, Su L, Ning X, Bai J, Lv X. Fluid flow and entropy generation analysis of $\mathrm{Al}_{2} \mathrm{O}_{3}$-water nanofluid in microchannel plate fin heat sinks. Entropy. 2019;21(8):739.

333. Narendran G, Gnanasekaran N, Perumal DA. Thermodynamic irreversibility and conjugate effects of integrated microchannel cooling device using $\mathrm{TiO}_{2}$ nanofluid. Heat Mass Transf Stoffuebertragung. 2019. https://doi.org/10.1007/s00231-019-02704-z.

334. Goodarzi M, Tlili I, Tian Z, Safaei MR. Efficiency assessment of using graphene nanoplatelets-silver/water nanofluids in microchannel heat sinks with different cross-sections for electronics cooling. Int J Numer Methods Heat Fluid Flow. 2019. https://doi. org/10.1108/HFF-12-2018-0730.

335. Alsarraf J, Shahsavar A, Khaki M, Ranjbarzadeh R, Karimipour A, Afrand M. Numerical investigation on the effect of four constant temperature pipes on natural cooling of electronic heat sink by nanofluids: a multifunctional optimization. Adv Powder Technol. 2019. https://doi.org/10.1016/j.apt.2019.10.035.

336. Adham AM. Ammonia base nanofluid as a coolant for electronic chips. Int J Mech Prod Eng Res Dev. 2019;9(3):569-80. https:// doi.org/10.24247/ijmperdjun201960.

337. Baïri A, Bauzin JG, Martín-Garín A, Alilat N, Millán-García JA. Natural convective cooling of electronics contained in tilted hemispherical enclosure filled with a porous medium saturated by water-copper nanofluid. Int J Numer Methods Heat Fluid Flow. 2019;29(1):280-93. https://doi.org/10.1108/HFF-01-2018-0036.

338. Baïri A, Laraqi N. Experimental quantification of natural convective heat transfer within annulus space filled with $\mathrm{H}_{2} \mathrm{O}-\mathrm{Cu}$ nanofluid saturated porous medium. Application to electronics cooling. Exp Heat Transf. 2019;32(4):364-75. https://doi. org/10.1080/08916152.2018.1526230.

339. Yang L, Huang JN, Mao M, Ji W. Numerical assessment of Ag-water nano-fluid flow in two new microchannel heatsinks: thermal performance and thermodynamic considerations. Int Commun Heat Mass Transf. 2020;110:104415. https://doi. org/10.1016/j.icheatmasstransfer.2019.104415.

340. Yang L, Du K, Zhang Z. Heat transfer and flow optimization of a novel sinusoidal minitube filled with non-Newtonian SiC/EGwater nanofluids. Int J Mech Sci. 2020;168:105310. https://doi. org/10.1016/j.jimecsci.2019.105310.

341. Elsaid AM. Experimental study on the heat transfer performance and friction factor characteristics of $\mathrm{CO}_{3} \mathrm{O}_{4}$ and $\mathrm{Al}_{2} \mathrm{O}_{3}$ based $\mathrm{H}_{2} \mathrm{O} /\left(\mathrm{CH}_{2} \mathrm{OH}\right)_{2}$ nanofluids in a vehicle engine radiator. Int Commun Heat Mass Transf. 2019;108:104263. https://doi. org/10.1016/j.icheatmasstransfer.2019.05.009.

342. Naiman I, Ramasamy D, Kadirgama K. Experimental and one dimensional investigation on nanocellulose and aluminium oxide hybrid nanofluid as a new coolant for radiator. IOP Conf Ser Mater Sci Eng. 2019;469:1. https://doi.org/10.1088/1757899x/469/1/012096.

343. Al Rafi A, Haque R, Sikandar F, Chowdhury NA. Experimental analysis of heat transfer with $\mathrm{CuO}, \mathrm{Al}_{2} \mathrm{O}_{3}$ /water-ethylene glycol nanofluids in automobile radiator. In: AIP Conference Proceedings; 2019, vol. 2121, https://doi.org/10.1063/1.5115878.

344. Kumar V, Sahoo RR. Exergy and energy analysis of a wavy fin radiator with variously shaped nanofluids as coolants. Heat Transf Asian Res. 2019;48(6):2174-92. https://doi.org/10.1002/ htj.21478. 
345. Contreras EMC, Oliveira GA, Filho EPB. Experimental analysis of the thermohydraulic performance of graphene and silver nanofluids in automotive cooling systems. Int J Heat Mass Transf. 2019;132:375-87. https://doi.org/10.1016/j.ijheatmasstrans fer.2018.12.014.

346. Said Z, et al. Enhancing the performance of automotive radiators using nanofluids. Renew Sustain Energy Rev. 2019;112:183-94. https://doi.org/10.1016/j.rser.2019.05.052.

347. Mahay N, Yadav RK. An experimental investigation into heat transfer characteristics of aqua based $\mathrm{Cu}$ nanofluid for automobile radiator. J Phys Conf Ser. 2019. https://doi.org/10.1088/17426596/1240/1/012043.

348. Soylu SK, Atmaca İ, Asiltürk M, Doğan A. Improving heat transfer performance of an automobile radiator using $\mathrm{Cu}$ and $\mathrm{Ag}$ doped $\mathrm{TiO}_{2}$ based nanofluids. Appl Therm Eng. 2019;157:113743. https ://doi.org/10.1016/j.applthermaleng.2019.113743.

349. Arunkumar T, Anish M, Jayaprabakar J, Beemkumar N. Enhancing heat transfer rate in a car radiator by using $\mathrm{Al}_{2} \mathrm{O}_{3}$ nanofluid as a coolant. Int J Ambient Energy. 2019;40(4):367-73. https:// doi.org/10.1080/01430750.2017.1392356.

350. Palaniappan B, Ramasamy V. Thermodynamic analysis of fly ash nanofluid for automobile (heavy vehicle) radiators. J Therm Anal Calorim. 2019;136(1):223-33. https://doi.org/10.1007/ s10973-018-7844-0.

351. Jadar R, Shashishekar KS, Manohara SR. Performance evaluation of Al-MWCNT based automobile radiator. Mater Today Proc. 2019;9:380-8. https://doi.org/10.1016/j.matpr.2019.02.167.

352. Toh LKL, Ting TW. Thermal performance of automotive radiator with graphene nanoplatelets suspension. AIP Conf Proc. 2019;2059:020012. https://doi.org/10.1063/1.5085955.

353. Maisuria MB, Sonar DM, Rathod MK, Bhatt MK. Experimental and analytical investigation on an automobile radiator with $\mathrm{CuO} /$ EG-water based nanofluid as coolant. Heat Transf Asian Res. 2019;48(6):2596-612. https://doi.org/10.1002/htj.21516.

354. Zhou XR, Wang Y, Zheng K, Huang H. Comparison of heat transfer performance of $\mathrm{ZnO}-\mathrm{PG}, \alpha-\mathrm{Al}_{2} \mathrm{O}_{3}-\mathrm{PG}$, and $\gamma-\mathrm{Al}_{2} \mathrm{O}_{3}-\mathrm{PG}$ nanofluids in car radiator. Nanomater Nanotechnol. 2019. https ://doi.org/10.1177/1847980419876465.

355. Akash AR, Abraham S, Pattamatta A, Das SK. Experimental assessment of the thermo-hydraulic performance of automobile radiator with metallic and nonmetallic nanofluids. Heat Transf Eng. 2019;41(3):235-51. https://doi.org/10.1080/01457 632.2018.1528055.

356. Akash A, Pattamatta A, Das S. Experimental study of the thermohydraulic performance of water/ethylene glycol-based graphite nanocoolant in vehicle radiators. J Enhanc Heat Transf. 2019;26(4):345-63.

357. Bondareva NS, Buonomo B, Manca O, Sheremet MA. Heat transfer performance of the finned nano-enhanced phase change material system under the inclination influence. Int J Heat Mass Transf. 2019;135:1063-72. https://doi.org/10.1016/j.ijheatmass transfer.2019.02.045.

358. Navarrete N, Mondragón R, Wen D, Navarro ME, Ding Y, Juliá JE. Thermal energy storage of molten salt -based nanofluid containing nano-encapsulated metal alloy phase change materials. Energy. 2019;167:912-9. https://doi.org/10.1016/j.energ y.2018.11.037.

359. Martín M, Villalba A, Fernández AI, Barreneche C. Development of new nano-enhanced phase change materials (NEPCM) to improve energy efficiency in buildings: Lab-scale characterization. Energy Build. 2019;192:75-83. https://doi.org/10.1016/j. enbuild.2019.03.029.

360. Ding M, Liu C, Rao Z. Experimental investigation on heat transfer characteristic of $\mathrm{TiO}_{2}-\mathrm{H}_{2} \mathrm{O}$ nanofluid in microchannel for thermal energy storage. Appl Therm Eng. 2019;160:114024. https://doi.org/10.1016/j.applthermaleng.2019.114024.
361. Harikrishnan S, Devaraju A, Kumar GR, Kalaiselvam S. Improved thermal energy storage behavior of a novel nanofluid as phase change material (PCM). Mater Today Proc. 2019;9:410 21. https://doi.org/10.1016/j.matpr.2019.02.170.

362. Cabeza LF, Castell A, Barreneche C, De Gracia A, Fernández AI. Materials used as PCM in thermal energy storage in buildings: a review. Renew Sustain Energy Rev. 2011;15:1675-95. https:// doi.org/10.1016/j.rser.2010.11.018.

363. Wang Q, Tang S, Tian S, Wei X, Peng T. Molecular simulations of adsorption and thermal energy storage of mixed R1234Ze/ UiO-66 nanoparticle nanofluid. J Nanomater. 2019. https://doi. org/10.1155/2019/5154173.

364. Zhou Y, Li Q, Wang Q. Energy storage analysis of UIO-66 and water mixed nanofluids: an experimental and theoretical study. Energies. 2019;12(13):1-9. https://doi.org/10.3390/en12132521.

365. Hassan MAM, Abdel-Hameed HM, Mahmoud OE. Experimental investigation of the effect of nanofluid on thermal energy storage system using clathrate. J Energy Resour Technol Trans ASME. 2019;141(4):1-8. https://doi.org/10.1115/1.4042004.

366. Hu Y, He Y, Zhang Z, Wen D. Enhanced heat capacity of binary nitrate eutectic salt-silica nanofluid for solar energy storage. Sol Energy Mater Sol Cells. 2019;192:94-102. https://doi. org/10.1016/j.solmat.2018.12.019.

367. Sheikholeslami M, Jafaryar M, Shafee A, Li Z. Hydrothermal and second law behavior for charging of NEPCM in a two dimensional thermal storage unit. Chin J Phys. 2019;58:244-52. https ://doi.org/10.1016/j.cjph.2019.02.001.

368. Chen M, He Y, Ye Q, Zhang Z, Hu Y. Solar thermal conversion and thermal energy storage of $\mathrm{CuO} / \mathrm{Paraffin}$ phase change composites. Int J Heat Mass Transf. 2019;130:1133-40. https://doi. org/10.1016/j.ijheatmasstransfer.2018.11.026.

369. Prasad AR, Kumar SKD, Banu TV, Vignesh T, Aatthisugan I. Synthesis and thermal energy storage analysis of copper oxide nano fluid for heat transfer applications. Int J Innov Technol Explor Eng. 2019;8(11):3616-9. https://doi.org/10.35940/ijite e.k2472.0981119.

370. Nithiyanantham U, Grosu Y, González-Fernández L, Zaki A, Igartua JM, Faik A. Corrosion aspects of molten nitrate saltbased nanofluids for thermal energy storage applications. Sol Energy. 2019;189:219-27. https://doi.org/10.1016/j.solen er.2019.07.050.

371. Farsani RY, Raisi A, Mahmoudi A. Successive melting and solidification of paraffin-alumina nanomaterial in a cavity as a latent heat thermal energy storage. J Braz Soc Mech Sci Eng. 2019. https://doi.org/10.1007/s40430-019-1859-8.

372. Qiao G, She X, Zhang T, Cong L, Chen YC, Ding Y. Mechanism of specific heat capacity enhancement of molten salts based nanofluids for thermal energy storage-a molecular study. In: 2019 Offshore Energy and Storage Summit, OSES 2019; 2019. pp. 1-7, https://doi.org/10.1109/OSES.2019.8867356.

373. Ji J, et al. Fabrication and characterization of phase change nanofluid with high thermophysical properties for thermal energy storage. J Mol Liq. 2019;284:23-8. https://doi. org/10.1016/j.molliq.2019.03.116.

374. Hadi A, Rashid FL, Hussein HQ, Hashim A. Novel of water with $\left(\mathrm{CeO}_{2}\right.$-WC) and ( $\left.\mathrm{SiC}-\mathrm{WC}\right)$ nanoparticles systems for energy storage and release applications. IOP Conf Ser Mater Sci Eng. 2019;518:3. https://doi.org/10.1088/1757$899 x / 518 / 3 / 032059$.

375. Sheikholeslami M, Shehzad SA, Li Z, Shafee A, Abbasi FM. Time dependent conduction heat transfer during solidification in a storage system using nanoparticles. Microsyst Technol. 2019;25(6):2153-69. https://doi.org/10.1007/s0054 2-018-4050-8.

376. Rahman S, Issa S, Said Z, El Assad MH, Zadeh R, Barani Y. Performance enhancement of a solar powered air conditioning 
system using passive techniques and SWCNT/R-407c nano refrigerant. Case Stud Therm Eng. 2019;16:100565. https://doi. org/10.1016/j.csite.2019.100565.

377. Jiang W, Li S, Yang L, Du K. Experimental investigation on performance of ammonia absorption refrigeration system with $\mathrm{TiO}_{2}$ nanofluid. Int J Refrig. 2019;98:80-8. https://doi.org/10.1016/j. ijrefrig.2018.09.032.

378. Jeyakumar N, Uthranarayan C, Narayanasamy B. Energy conservation in the refrigeration system through improvement of Coefficient of Performance and power consumption reduction using Nanofluids. Int J Ambient Energy. 2019. https://doi. org/10.1080/01430750.2019.1687333.

379. Ahmed MS, Elsaid AM. Effect of hybrid and single nanofluids on the performance characteristics of chilled water air conditioning system. Appl Therm Eng. 2019;163:114398. https://doi. org/10.1016/j.applthermaleng.2019.114398.

380. Nourafkan E, Asachi M, Jin H, Wen D, Ahmed W. Stability and photo-thermal conversion performance of binary nanofluids for solar absorption refrigeration systems. Renew Energy. 2019;140:24-273. https://doi.org/10.1016/j.renene.2019.01.081.

381. Esfe MH, Dalir R, Bakhtiari R, Afrand M. Simultaneous effects of multi-walled carbon nanotubes and copper oxide nanoparticles on the rheological behavior of cooling oil: application for refrigeration systems. Int J Refrig. 2019;104:123-33. https://doi. org/10.1016/j.ijrefrig.2018.11.036.

382. Aprea C, Greco A, Maiorino A, Masselli C. Enhancing the heat transfer in an active barocaloric cooling system using ethylene-glycol based nanofluids as secondary medium. Energies. 2019;12:15. https://doi.org/10.3390/en12152902.

383. Safaei MR, Ranjbarzadeh R, Hajizadeh A, Bahiraei M, Afrand M, Karimipour A. Effects of cobalt ferrite coated with silica nanocomposite on the thermal conductivity of an antifreeze: new nanofluid for refrigeration condensers. Int J Refrig. 2019;102:8695. https://doi.org/10.1016/j.ijrefrig.2018.12.007.

384. Mohammed HI, Giddings D, Walker GS. Experimental investigation of nanoparticles concentration, boiler temperature and flow rate on flow boiling of zinc bromide and acetone solution in a rectangular duct. Int J Heat Mass Transf. 2019;130:710-21. https ://doi.org/10.1016/j.ijheatmasstransfer.2018.10.115.

385. Pourfayaz F, Imani M, Mehrpooya M, Shirmohammadi R. Process development and exergy analysis of a novel hybrid fuel cell-absorption refrigeration system utilizing nanofluid as the absorbent liquid. Int J Refrig. 2019;97:31-41. https://doi. org/10.1016/j.ijrefrig.2018.09.011.

386. Bondre D, Joshi A, Shinde T, Deshmukh A, Dhanawade K. Experimental performance and analysis of domestic refrigeration system using nano-refrigerants. In: Proceedings of International Conference on Intelligent Manufacturing and Automation. Lecture Notes in Mechanical Engineering; 2019. https://doi. org/10.1007/978-981-13-2490-1_35.

387. Modi N, Pandya B, Patel J. Comparative analysis of a solardriven novel salt-based absorption chiller with the implementation of nanoparticles. Int J Energy Res. 2019;43(4):1563-77. https://doi.org/10.1002/er.4405.

388. Adelekan DS, Ohunakin OS, Gill J, Atiba OE, Okokpujie IP, Atayero AA. Experimental investigation of a vapour compression refrigeration system with $15 \mathrm{~nm} \mathrm{TiO2-R600a} \mathrm{nano-refrigerant}$ as the working fluid. In: Procedia Manufacturing; 2019. pp. 1222-1227, https://doi.org/10.1016/j.promfg.2019.06.079.

389. Nazari S, Safarzadeh H, Bahiraei M. Experimental and analytical investigations of productivity, energy and exergy efficiency of a single slope solar still enhanced with thermoelectric channel and nanofluid. Renew Energy. 2019;135:729-44. https://doi. org/10.1016/j.renene.2018.12.059.

390. Nazari S, Safarzadeh H, Bahiraei M. Performance improvement of a single slope solar still by employing thermoelectric cooling channel and copper oxide nanofluid: an experimental study. J Clean Prod. 2019;208:1041-52. https://doi.org/10.1016/j.jclep ro.2018.10.194.

391. Rafiq M, Chengrong L, Lv Y. Effect of $\mathrm{Al}_{2} \mathrm{O}_{3}$ nanorods on dielectric strength of aged transformer oil/paper insulation system. J Mol Liq. 2019;284:700-8. https://doi.org/10.1016/j.molli q.2019.04.041.

392. Pak BC, Cho YI. Hydrodynamic and heat transfer study of dispersed fluids with submicron metallic oxide particles. Exp Heat Transf. 1998;11(2):151-70. https://doi.org/10.1080/0891615980 8946559.

Publisher's Note Springer Nature remains neutral with regard to jurisdictional claims in published maps and institutional affiliations. 